UNIVERSIDADE DE SÃO PAULO

FACULDADE DE EDUCAÇÃO

JÉSSICA MUNHOZ ARAÚJO BRAZ

Práticas de diferenciação pedagógica na rede municipal de São Paulo

VERSÃO REVISADA

São Paulo 
UNIVERSIDADE DE SÃO PAULO

FACULDADE DE EDUCAÇÃO

JÉSSICA MUNHOZ ARAUJO BRAZ

\section{Práticas de diferenciação pedagógica na rede municipal de São Paulo}

Dissertação apresentada à Banca Examinadora da Faculdade de Educação da Universidade de São Paulo (FEUSP) como exigência parcial para obtenção do título de Mestre na área de Educação.

Área de concentração: Didática e Práticas de Ensino

Orientadora: Profa. Dra. Adriana Bauer

VERSÃO REVISADA

São Paulo 
AUTORIZO A REPRODUÇÃO E DIVULGAÇÃO TOTAL OU PARCIAL DESTE TRABALHO, POR QUALQUER MEIO CONVENCIONAL OU ELETRÔNICO, PARA FINS DE ESTUDO E PESQUISA, DESDE QUE CITADA A FONTE.

Catalogação na Publicação

Serviço de Biblioteca e Documentação

Faculdade de Educação da Universidade de São Paulo

372.22 Braz, Jéssica Munhoz Araújo

B827p Práticas de diferenciação pedagógica na rede municipal de São Paulo / Jéssica Munhoz Araújo Braz; orientação Adriana Bauer. São Paulo: s.n., 2018.

136 p.; tabs.; apêndice

Dissertação (Mestrado - Programa de Pós-Graduação em Educação. Área de Concentração: Didática, Teorias de Ensino e Práticas Escolares) - Faculdade de Educação da Universidade de São Paulo.

1. Diferenciação Pedagógica 2. Ciclo de alfabetização 3. Diferenciação do ensino I. Bauer, Adriana, orient. 
Nome: BRAZ, Jéssica Munhoz Araújo

Título: Práticas de diferenciação pedagógica na rede municipal de São Paulo: mapeamento e caracterização

Dissertação de mestrado apresentada à Banca Examinadora da Faculdade de Educação da Universidade de São Paulo, sob orientação da Profa. Dra. Adriana Bauer, para obtenção do título de Mestre em Educação. Área de concentração: Didática e práticas de ensino.

Aprovado em:

Banca examinadora:

Prof. Dr.

Instituição:

Julgamento:

Assinatura:

Prof. Dr. Instituição:

Julgamento: Assinatura:

Prof. Dr. Instituição:

Julgamento: Assinatura: 
"Não sei como pareço aos olhos do mundo, mas eu mesmo vejo-me como um pobre garoto que brincava na praia e se divertia em encontrar uma pedrinha mais lisa uma vez por outra, ou uma concha mais bonita do que de costume, enquanto o grande oceano da verdade se estendia totalmente inexplorado diante de mim.',

Isaac Newton 


\section{DEDICATÓRIA}

À memória do meu amado pai, Luiz Carlos, que tanto me incentivou na jornada educacional e, especialmente, na realização deste mestrado, no qual com grande alegria me viu entrar...mas mesmo não tendo a oportunidade de ver o fim deste trabalho, não deixou de ser a minha inspiração para a sua conclusão... 


\section{AGRADECIMENTOS}

À Deus, em primeiro lugar, por me ter conduzido e aberto todos os meus caminhos, permitindo que eu chegasse até aqui. Sem ELE nada teria sido seria possível.

À minha orientadora $\operatorname{Prof}^{a}$. Adriana Bauer, pela paciência, dedicação, atenção, broncas e pelas inúmeras e incansáveis orientações, que contribuíram para a conclusão deste trabalho.

À minha mãe Márcia e meu irmão Bruno, que acompanharam essa trajetória desde o início, entendendo minhas ausências e correrias, e ajudando sempre que precisei, especialmente com o pequeno Luiz Gabriel.

Ao meu esposo Gabriel, pela compreensão, ajuda, incentivo...e por me ter abraçado quando achei que nada mais daria certo.

Ao meu filho, Luiz Gabriel, que chegou de surpresa me trazendo uma das maiores alegrias que eu poderia sentir, e que com cada sorriso me impulsionava a continuar.

Aos professores Jefferson Mainardes, da Universidade Federal de Ponta Grossa e Elba Siqueira de Sá Barreto, da Faculdade de Educação da USP, pelas valiosas contribuições na banca do exame de qualificação.

Às Diretorias Regionais de Ensino de Butantã, Ipiranga e Itaquera, por permitirem a realização desta pesquisa.

À Escola Municipal de Ensino Fundamental denominada IQ 7, especialmente à sua diretora, por ter aberto as portas de sua unidade para as observações da pesquisa.

À minha diretora e sua equipe de gestão, por compreenderem minhas ausências em função de atividades do mestrado. 


\section{RESUMO}

BRAZ, Jéssica Munhoz Araújo. Práticas de diferenciação pedagógica na rede municipal de São Paulo. 2018. 134 p. Dissertação (Mestrado) - Faculdade de Educação, Universidade de São Paulo, São Paulo, 2018.

Esta pesquisa tem como objetivo analisar práticas de diferenciação pedagógica em escolas da rede municipal de educação de São Paulo. O conceito de diferenciação pedagógica emerge com a problemática do fracasso escolar, decorrente da universalização do ensino público. Neste trabalho, a partir da delimitação e discussão do conceito de diferenciação pedagógica, busca-se identificar a presença de ações diferenciadas de ensino em instituições da rede municipal de São Paulo, procurando-se responder às seguintes questões: qual é a característica das ações desenvolvidas e qual é o entendimento que os docentes têm acerca do conceito de diferenciação pedagógica? De que forma este entendimento se reflete nas práticas em sala de aula? Para responder a estas questões, procedeu-se à revisão de literatura sobre a temática da diferenciação pedagógica, bem como coletaram-se informações sobre a realidade empírica por meio da aplicação de 102 questionários, 4 entrevistas e observações in loco em 12 salas de aula de uma escola da Zona Leste de São Paulo. O estudo focalizou o trabalho dos professores do ciclo de alfabetização - composto pelos $1^{\circ} \mathrm{s}, 2^{\circ}$ s e $3^{\circ}$ s anos do Ensino Fundamental - no componente de Língua Portuguesa. Os resultados obtidos mostraram que os docentes afirmam realizar práticas de diferenciação pedagógica com seus alunos; porém, os dados empíricos mostraram que as práticas, relatadas e observadas, não se coadunam com os princípios preconizados por autores que discutem a temática, como Perrenoud, Roldão, Tomlinsom, Pacheco entre outros. Além disso, observou-se que, ainda que documentos curriculares oficiais, produzidos nos âmbitos federal, estadual e municipal, remetam a princípios de diferenciação pedagógica, não são encontradas referências diretas a esse conceito.

Palavras-chave: diferenciação pedagógica; pedagogia diferenciada; ciclo de alfabetização; diferenciação do ensino; práticas diferenciadas de ensino. 


\begin{abstract}
BRAZ, Jessica Munhoz Araujo. Differentiated pedagogical practices in municipal schools in São Paulo: 2018, 134 p. Dissertação (Mestrado) - Faculdade de Educação, Universidade de São Paulo, São Paulo, 2018.

This research aims to analyze practices of pedagogical differentiation in schools of the municipal education network of São Paulo. The concept of pedagogical differentiation emerges with the problem of school failure, resulting from the universalization of public education. In this work, from the delimitation and discussion of the concept of pedagogical differentiation, we seek to identify the presence of differentiated teaching actions in institutions of the municipal network of São Paulo, seeking to answer the following questions: what is the characteristic of the actions developed and what is the understanding that teachers have about the concept of pedagogical differentiation? How is this understanding reflected in classroom practices? In order to answer these questions, a literature review on the subject of pedagogical differentiation was carried out, as well as information on the empirical reality through the application of 102 questionnaires, 4 interviews and on-site observations in 12 classrooms of one school in the East Zone of São Paulo. The study focused on the work of the teachers of the literacy cycle - composed of the 1st, 2nd and 3rd years of elementary education - in the Portuguese Language component. The results showed that the teachers affirm the practice of pedagogical differentiation with their students; however, the empirical data showed that the practices, reported and observed, are not in line with the principles advocated by authors who discuss the subject, such as Perrenoud, Roldão, Tomlinsom, Pacheco and others. In addition, it was observed that, although official curricular documents produced at the federal, state and municipal levels refer to principles of pedagogical differentiation, no direct references to this concept are found.
\end{abstract}

Key-words: pedagogical differentiation; differentiated pedagogy; literacy cycle; differentiation of teaching; differentiated teaching practices. 


\section{LISTA DE TABELAS}

Tabela 1 - Funções docentes dos professores que responderam ao questionário...............76

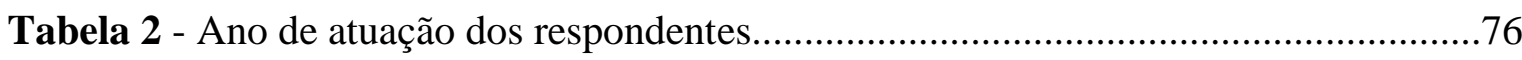

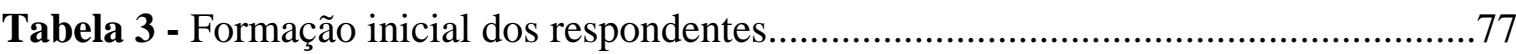

Tabela 4 - Formação complementar dos respondentes....................................................78

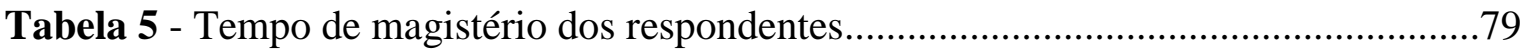

Tabela 6 - Tempo de experiência dos respondentes no ano em que lecionam...................80

Tabela 7 - Conceitos relativos à diferenciação pedagógica conhecidos pelos respondentes.

Tabela 8 - Classificação das explicações dadas pelos respondentes sobre o conceito de diferenciação pedagógica

Tabela 9 - Frequência absoluta e relativa dos tipos de diferenciação pedagógica realizados pelos respondentes.

Tabela 10 - Frequência absoluta e relativa de tipos de diferenciação praticados em cada diretoria.

Tabela 11 - Categorização da adequação das práticas descritas pelos docentes com base na teorização.

Tabela 12 - Frequência absoluta e relativa de práticas de diferenciação pedagógica condizentes - ou não - com os princípios teóricos.

Tabela 13 Categorização de práticas descritas pelos respondentes, de acordo com os tipos de diferenciação

Tabela 14 - Justificativas sobre a importância da diferenciação, conforme os respondentes

Tabela 15 - Expressões e termos citados pelos respondentes para se referir ao conceito de diferenciação pedagógica.

\section{LISTA DE FIGURAS}

Figura 1 - Organograma dos tipos de diferenciação por Tracey Hall. 


\section{LISTA DE SIGLAS}

DCN's Diretrizes Curriculares Nacionais

DRE Diretoria Regional de Ensino

EMEF Escola Municipal de Ensino Fundamental

FEUSP Faculdade de Educação da Universidade de São Paulo

PCN's Parâmetros Curriculares Nacionais

PNE Plano Nacional de Educação

PMSP Prefeitura Municipal de São Paulo

PNAIC Pacto Nacional pela Alfabetização na Idade Certa

SCIELO Scientific Eletronic Library On-Line

SEB Secretaria de Educação Básica

UEPG Universidade Estadual de Ponta Grossa

USP Universidade de São Paulo 


\section{SUMÁRIO}

\section{INTRODUÇÃO}

A DIFERENCIAÇÃO PEDAGÓGICA COMO ALTERNATIVA PARA A SUPERAÇÃO DO FRACASSO ESCOLAR...................................................... 13

\section{CAPÍTULO I}

\section{DIFERENCIAÇÃO PEDAGÓGICA: ORIGEM, PERSPECTIVAS E}

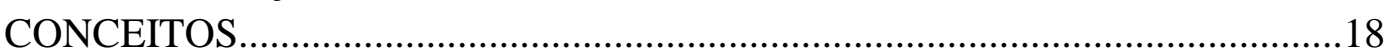

I.1 - As origens da diferenciação pedagógica...................................................20

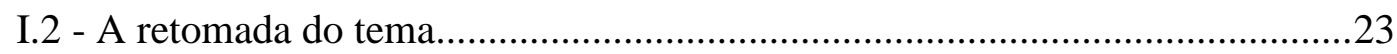

I.3 - Diferenciação pedagógica: características essenciais de diferentes aportes...27

I.3.1 - Aportes da literatura acadêmica portuguesa...............................................2 27

I.3.2 - Aportes da literatura acadêmica americana e britânica............................... 33

I.3.3 - Aportes de Phillipe Perrenoud..................................................................41

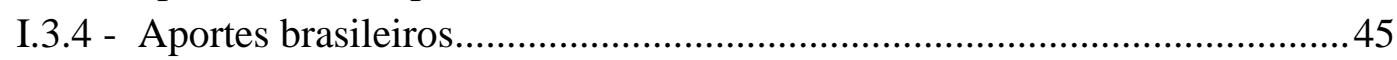

I.3.4.1 - Literatura acadêmica brasileira...........................................................45

I.3.4.2 - Legislação curricular brasileira e diferenciação pedagógica.....................49

I.3.4.2.1 - Diretrizes Curriculares Nacionais da Educação Básica.........................50

I.3.4.2.2 Parâmetros Curriculares Nacionais..........................................................51

I.3.4.2.3 - Orientações curriculares e Expectativas de Aprendizagem no Ensino

Fundamental Ciclo I - Prefeitura de São Paulo........................................................53

1.3.4.2.4 - Pacto Nacional para Alfabetização na Idade Certa -

Portaria No 826 de 17 de Julho de 2017 e documentos orientadores do PNAIC....55

I.3.5 - A diferenciação implícita no discurso....................................................... 58

I.4 Semelhanças e diferenças entre as diferentes perspectivas............................61

\section{CAPÍTULO II}

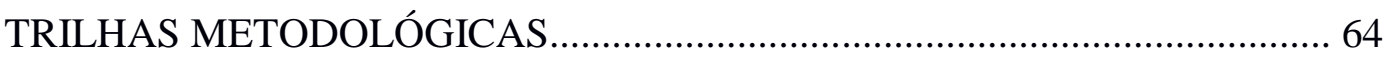

II.1 - Método científico: escolha e consolidação de uma pesquisa de

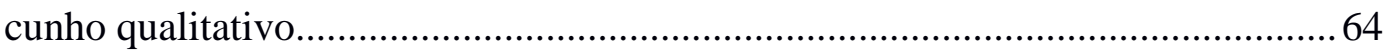

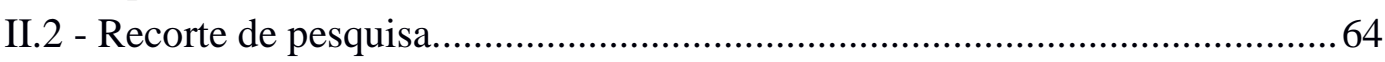

II.3 - O caminho inicial: levantamento bibliográfico e construção dos

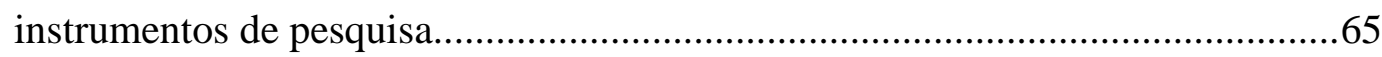

II.3.1 - Seleção e organização da pesquisa bibliográfica......................................65

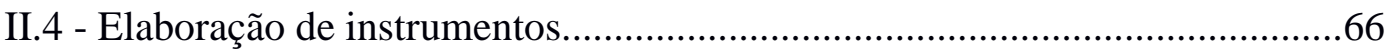

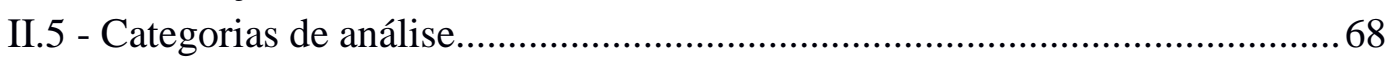

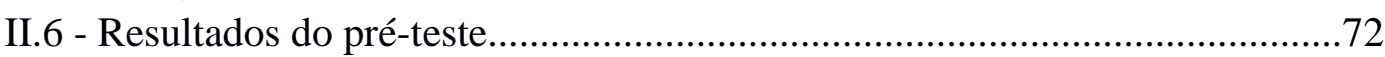

CAPÍTULO III

EXPERIÊNCIAS DE CAMPO: DESCRIÇÃO, CONTEXTUALIZAÇÃO E ANÁLISE.

III.1 - Aplicação dos questionários e análise dos resultados nas Diretorias

Regionais de Ensino: Butantã, Ipiranga e Itaquera............................................ 75

III.2 - Análise dos resultados dos questionários.............................................. 76 


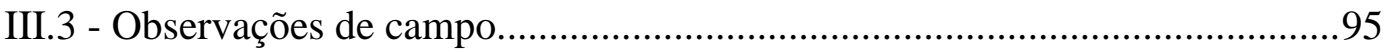

III.4. Diferenciação pedagógica na EMEF IQ 7: possibilidades e limites.............. 96

CAPÍTULO IV

ANÁLISE E DISCUSSÃO DOS RESULTADOS COM BASE NA

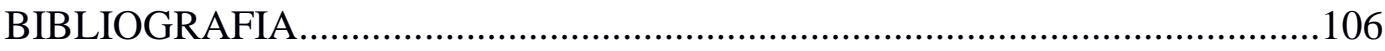

IV.1 - Conhecimento docente sobre diferenciação: embasamento teórico ou

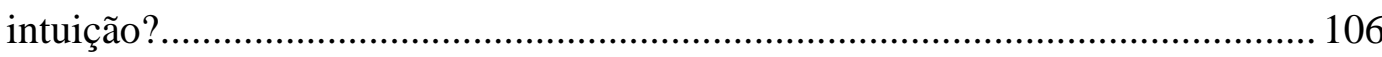

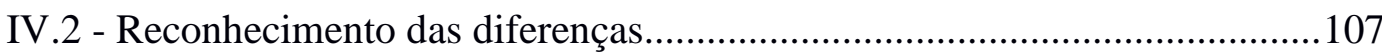

IV.3 - O foco na dificuldade e a falta de atenção às demais diferenças................108

IV.4 - Equívocos sobre as práticas de diferenciação..........................................111

IV.5 - A dificuldade de se desenvolver um trabalho pedagógico diferenciado... 111

IV.6 - O currículo na perspectiva diferenciada de ensino.................................. 112

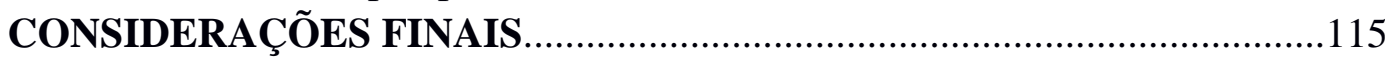

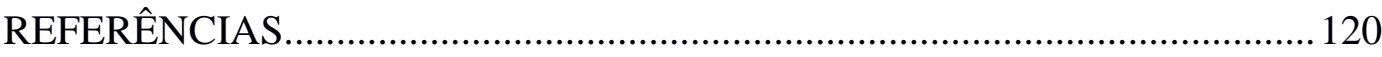

APÊNDICE - A

RESULTADOS DAS BUSCAS BIBLIOGRÁFICAS...................................... 123

APÊNDICE - B

INSTRUMENTOS DE PESQUISA: QUESTIONÁRIO, ROTEIROS DE

ENTREVISTAS E DE OBSERVAÇÕES

APÊNDICE - C. 


\section{INTRODUÇÃO}

\section{A DIFERENCIAÇÃo PEDAGÓgICA COMO ALTERNATIVA PARA A SUPERAÇÃO DO FRACASSO ESCOLAR}

Esta pesquisa tem como objetivo identificar práticas de diferenciação pedagógica da rede municipal de ensino de São Paulo, bem como caracterizar a forma como essas ações são desenvolvidas.

As práticas de diferenciação pedagógica referem-se à necessidade de se considerar a heterogeneidade existente entre os alunos para, a partir daí, proporcionar aprendizagens significativas para todos, contribuindo, de forma expressiva, para a redução dos níveis de fracasso escolar, ao permitir que "cada aprendiz vivencie, tão frequentemente quanto possível, situações fecundas de aprendizagem" (PERRENOUD, 2000, p. 9).

Mas, o que é diferenciar o ensino? Em primeiro lugar, diferenciar o ensino implica reconhecer que toda turma é composta por alunos muito diferentes entre si, e que é preciso orientar a ação pedagógica, levando essa diversidade em conta. A diferenciação pedagógica está relacionada à didática, ao currículo, ao questionamento sobre o sentido do trabalho escolar e à relação com os saberes e sua utilização; não se pode pensar neste conceito sob um ponto de vista estritamente cognitivo.

Portanto, diferenciar é ensinar de modo que cada aluno esteja sempre diante de situações didáticas propícias para a sua aprendizagem, o que exclui as situações que não trazem desafios ou que proponham desafios fora do alcance dos alunos, que são as grandes fontes de desmotivação dentro do contexto de aprendizagem, contribuindo para a produção do fracasso dentro da escola. $\mathrm{O}$ ensino deve fazer sentido para que o aprendente sinta-se interessado por ele.

Como será explorado no Capítulo I, é difícil definir com precisão a origem do conceito de diferenciação pedagógica. Conforme aponta Gomes (2013), os escritos relacionados com o tema perdem-se na história da educação, pois antes mesmo que se estabelecessem as pedagogias tradicionais, diversos autores já faziam menção àquilo que hoje se conhece como diferenciação pedagógica, ainda que sem utilizar propriamente essa terminologia.

Todavia, o debate sobre a diferenciação do ensino teve origem nas discussões ocorridas em diversos contextos educacionais, em que se deparavam com altos níveis de insucesso dentro das escolas, após sua maior abertura à população, com a universalização do ensino público, o que ocorreu no Brasil por volta dos anos 1950 e 1960 (GOMES, 2013). A 
escola, que por muito tempo foi um privilégio para poucos, abriu suas portas a um público de características diversas e que não tinha acesso à escolarização formal.

Como decorrência dessa expansão, a instituição que antes estava acostumada a lidar com uma parcela mais restrita da sociedade, ou seja, a que englobava as camadas de maior poder aquisitivo, teve dificuldade em lidar com as diferenças que começavam a constituir sua nova realidade, sem considerar as diversas necessidades trazidas por esse público, gerando níveis elevados de fracasso escolar.

A escola continuou, assim, oferecendo o mesmo ensino a todos, tal como estava habituada a fazer. Mas, a homogeneização das práticas exercidas não permitia que o público fosse atendido em suas especificidades, o que fez com que, por conta da resposta oferecida pela escola, muitos alunos começassem a fracassar. É com base neste quadro de insucessos que novas teorias educacionais começam a ser discutidas, buscando-se alternativas para combater o fracasso prevalente. Nesse contexto, a diferenciação aparece como uma solução possível ao problema em questão, passando a compor a pauta de discussões educacionais que reconhecem o acesso à educação como uma condição necessária ao desenvolvimento das sociedades (CORTESÃO, 1998).

Pressupõe-se, portanto, que uma educação pautada em práticas diferenciadas de ensino seja capaz de combater e diminuir os índices de fracasso escolar, justamente por considerar as diferenças presentes entre os alunos e, a partir dessas diferenças, traçar estratégias e propor situações de aprendizagem significativas a todos. Consequentemente, com a diminuição dos índices de fracasso escolar, obter-se-iam resultados de aprendizagem satisfatórios, aumentando, portanto, o sucesso dos alunos em sua trajetória escolar.

No entanto, mesmo com a importância dada à diferenciação pedagógica no combate às desigualdades e ao fracasso escolar, a discussão sobre o tema parece não ter ganhado tanto espaço dentro das políticas educacionais e das produções acadêmicas no Brasil. A pesquisa realizada para a obtenção da bibliografia de base deste trabalho constatou que ainda existem poucas publicações abordando tal temática no país, dentre as quais podemos citar André (2006) e Mainardes (2007, 2009).

Com relação às produções em nível de mestrado e doutorado, também não foi localizado um número expressivo de estudos sobre diferenciação no meio acadêmico brasileiro. Os dados obtidos, bem como o caminho utilizado para o levantamento bibliográfico realizado são descritos detalhadamente no Capítulo III, que trata da abordagem metodológica adotada na pesquisa. 
De todo modo, o volume de produções sobre diferenciação pedagógica existentes no Brasil ainda deixa, portanto, um caminho a ser percorrido, abrindo espaço para que outros estudos venham a ser desenvolvidos acerca desta temática. A relevância do tema da diferenciação pedagógica para o contexto educacional brasileiro pode ser justificada pelo fato deste sistema ser composto por um público extremamente heterogêneo, que apresenta entre si diferenças de várias ordens. Tais diferenças devem ser respeitadas e tratadas de forma adequada, pois o não respeito a elas tem feito com que vários alunos fracassem em seus percursos educacionais, carregando dificuldades permanentes em toda a sua trajetória escolar.

É nessa lacuna que se espera que este trabalho possa oferecer contribuições ao campo da educação e, mais especificamente, à área do currículo e das práticas de ensino, visto que a temática é aqui entendida como uma possível estratégia para a superação das formas de fracasso escolar presentes em diversos sistemas educacionais, incluindo o brasileiro.

Considerando o contexto brasileiro, rico e diverso, também é de se esperar que o sucesso seja alcançado com base na consideração e valorização dessas diferenças.

Assim, tendo em vista esta realidade, questiona-se: o que vem sendo feito na rede municipal de São Paulo para se combater o fracasso escolar? Dentre as medidas tomadas, existem ações de diferenciação pedagógica, ainda que não exista uma discussão mais aprofundada sobre o tema?

Essas questões direcionam o presente estudo, que tem, como objetivos, os destacados a seguir.

\section{Objetivos do estudo}

Entendendo-se que a diferenciação pedagógica pode ser um mecanismo capaz de diminuir as desigualdades na educação e, consequentemente, os índices de fracasso escolar, justifica-se a necessidade de investigar a existência de práticas diferenciadas na rede municipal de São Paulo e caracterizar a forma como essas práticas estão sendo realizadas.

Para além de discutir o conceito de diferenciação pedagógica, esta pesquisa se propõe a refletir se os docentes conhecem, de fato, o conceito de diferenciação pedagógica e a identificar ações de diferenciação pedagógica de professores da rede municipal de ensino de São Paulo.

No escopo da investigação, questiona-se: o conceito da diferenciação pedagógica é de uso comum entre os professores de escolas da rede municipal de São Paulo? Se sim, que significados e entendimentos lhe são atribuídos? Se não, é possível identificar práticas de diferenciação pedagógica no cotidiano escolar, ainda que os professores não as verbalizem em 
seus discursos? Quais são as características das práticas de diferenciação propostas pelos professores? A diferenciação constitui-se como parte integrante do projeto pedagógico da escola ou como uma prática isolada dos professores? Como objetivos específicos, busca-se:

1- Identificar se a proposta da diferenciação se faz presente nos documentos oficiais da Secretaria de Educação da rede municipal de São Paulo;

2- Identificar a existência de práticas da diferenciação pedagógica em instituições de ensino da rede municipal de São Paulo, especificamente em turmas que compõem o ciclo de alfabetização, a saber, dos $1^{\circ}$ s, $2^{\circ}$ s e $3^{\circ}$ s anos do Ensino Fundamental I;

3- Caracterizar de que forma as práticas de diferenciação pedagógica ocorrem;

4- Apreender quais são os entendimentos que os docentes possuem acerca do conceito de diferenciação pedagógica.

5- Compreender possibilidades e limites da diferenciação pedagógica para o combate ao fracasso escolar.

A pesquisa, de cunho qualitativo, foi desenvolvida a partir da vertente exploratória, e utilizou os seguintes instrumentos e técnicas: aplicação de questionário; observações in loco; entrevistas; e análise documental. Todo o desenho metodológico construído, bem como a descrição e os exemplares dos instrumentos utilizados (questionários, roteiros de observação, categorias de análise, roteiros de entrevista) serão detalhados no capítulo sobre Metodologia e estarão disponíveis para consulta no Apêndice deste trabalho.

Com relação ao recorte de pesquisa, o estudo focalizou os anos iniciais do Ensino Fundamental I, mais especificamente, os que compõem o Ciclo de Alfabetização da Rede Municipal de São Paulo: $1^{\circ} \mathrm{s}, 2^{\circ} \mathrm{s}$ e $3^{\circ} \mathrm{s}$ anos. Tal escolha justifica-se por considerar-se a importância atribuída à alfabetização nos anos iniciais, como fase basilar de todo o processo de ensino. Conforme aponta Mainardes (2007, p. 7), “a garantia da apropriação da leitura e escrita, no menor tempo possível, precisa ser tomada como uma tarefa prioritária, principalmente nas classes onde já seria esperado que os alunos estivessem alfabetizados", como é o caso de $2^{\circ} \mathrm{s}$ e $3^{\circ} \mathrm{s}$ anos do Ensino Fundamental I. Considera-se que, se a criança não realiza aprendizagens esperadas, já nesta fase inicial, ela poderá vivenciar um processo de exclusão dentro da própria escola.

Nesse sentido, a diferenciação assume um papel de suma importância, pois considera os diferentes ritmos e formas de aprender dos alunos, procurando assegurar que todos alcancem os direitos de aprendizagem propostos para cada ano.

No Capítulo I, apresenta-se a revisão da bibliografia utilizada na construção do referencial teórico desta pesquisa, elencando as principais contribuições obtidas, bem como 
procurando pontuar semelhanças e diferenças entre as mesmas. São ainda apresentados e analisados alguns dos documentos oficiais que tratam do currículo e de orientações pedagógicas elaborados em âmbito federal, estadual e municipal, a fim de se localizar possíveis referências às práticas de diferenciação.

No Capítulo II, são apresentados os caminhos metodológicos adotados para a execução desta pesquisa, assim como a formulação dos instrumentos construídos para as diversas fases deste trabalho.

No Capítulo III, são descritos e analisados os resultados obtidos com os questionários respondidos por professores do Ciclo de Alfabetização de Diretorias de Ensino (DRE) e reportadas as experiências de campo em uma escola da rede municipal escolhida, para a realização desta pesquisa, a partir das respostas obtidas no questionário inicial.

No Capítulo IV, discutem-se os dados obtidos por meio dos questionários e das observações de campo, realizadas à luz das teorias utilizadas, e apresentam-se os resultados finais da pesquisa. -

Nas Considerações Finais retomam-se as questões iniciais e discute-se em que medida foi possível respondê-las, destacando-se as aprendizagens propiciadas no percurso acerca das práticas de diferenciação pedagógica no Brasil, bem como os limites da pesquisa. 


\section{CAPÍTULO I}

\section{DIFERENCIAÇÃO PEDAGÓGICA: ORIGEM, PERSPECTIVAS E CONCEITOS}

Ainda que não seja muito discutida em território nacional, a ideia de diferenciar o ensino não é recente. Conforme mencionado na introdução deste trabalho, é possível encontrar algumas referências à diferenciação desde a época em que começaram a surgir as pedagogias escolanovistas, nos escritos de diversos autores, como Édouard Claparéde, Jean Ovide Decroly, John Dewey, dentre outros (GOMES, 2013). A ideia de se diferenciar está ligada ao reconhecimento da importância do caráter individual que o processo educativo assume, conforme as especificidades dos educandos. De acordo com Roldão:

O conceito de diferenciação na aprendizagem não é uma construção recente na história da educação e na teoria curricular. O reconhecimento do caráter específico e individual do processo de aprendizagem remonta aos escritos de Comênio e Rosseau e de muitos pedagogos que nos séculos XIX e início do $\mathrm{XX}$ se interessaram pelas questões da aprendizagem, como Montessori, Decroly e Kilpatrick, (ROLDÃO, 2003, p. 34).

Perrenoud (2000) corrobora com a ideia de que a reconstituição da trajetória das representações e das práticas diferenciadas de ensino não é uma tarefa simples. Segundo o autor, considerando-se a existência da pluralidade de perspectivas teóricas que se dispuseram a questionar as formas tradicionais de ensino, bem como a "disparidade das conjunturas das políticas nacionais" (PERRENOUD, 2000, p. 37), os movimentos relacionados à discussão e promoção de práticas diferenciadas de ensino configuram-se mais como evoluções paralelas do que como um movimento único (PERRENOUD, 2000).

Exemplificam esse movimento: as teorias escolanovistas em países como a França e Bélgica, que, conforme já mencionado, defendiam ideias de diferenciação, ainda que sem citar essa terminologia; a defesa da instrução diferenciada (differentiated instruction) nos Estados Unidos; a criação de experiências educativas que preconizavam a diferenciação no ensino, como a escola da Ponte, em Portugal, acompanhada das amplas discussões realizadas no país acerca do tema, dentre outras. Embora tenham ocorrido em lugares distintos, todos esses movimentos têm em comum a preocupação de se atentar às diferenças existentes entre os educandos, a fim de desenvolver estratégias de ensino capazes de promover o sucesso em suas trajetórias escolares.

No entanto, mesmo sendo possível encontrar indícios de uma pedagogia diferenciada nos escritos de diversos autores (CLAPARÉDE, 1973; CORTESÃO, 1998; PERRENOUD, 
2000; ROLDÃO, 2003; MAINARDES, 2007; PACHECO 2008; HALL, 2011) e em diferentes épocas, as discussões sobre o tema começam a se consolidar nos debates educacionais a partir do momento em que o fracasso escolar é tido como um problema e, portanto, como um desafio a ser enfrentado pela escola.

Esse reconhecimento ocorre, conforme colocam Masini (1993) e Gomes (2008), no século XX, por volta dos anos 1960 e 1970, na Europa, e no final dos anos 1980, no Brasil, quando se estabelece o acesso à educação como direito subjetivo aos cidadãos, e são colocadas em prática as políticas de universalização do ensino, o que não só evidencia, mas aumenta o fracasso nas escolas (CORTESÃO; 1998; ROLDÃO, 2003).

Assim sendo, como o fracasso passa a ser encarado como um entrave sério ao desenvolvimento dos sistemas escolares, a busca por formas de combatê-lo faz com que a diferenciação pedagógica seja vista como uma possível solução ao problema. É importante dizer que o fracasso a que se refere este trabalho não é aquele resultante da evasão escolar, mas sim da não aprendizagem, dos resultados alcançados - ou não - pelos que frequentam a escola regularmente.

Na literatura estudada, diversos são os termos utilizados pelos autores para tratar das práticas de diferenciação pedagógica. Perrenoud (2000), um dos principais autores que escreve sobre o tema, utiliza em suas produções o termo pedagogia diferenciada, definindo-o como sendo uma pedagogia racional, na medida em que é capaz de proporcionar aprendizagens significativas para todos.

O autor também baseia a discussão sobre o conceito de diferenciação pedagógica na análise da gênese do fracasso escolar, decorrente da abertura da escola às massas e da dificuldade que a instituição escolar encontrou diante da diversidade de alunos que nela adentrava. A busca por respostas pedagógicas para a questão do fracasso escolar é retomada em torno do desenvolvimento de dispositivos de pedagogia diferenciada (PERRENOUD, 2000).

As produções norte-americanas falam em instrução diferenciada (differentiated instruction) (TOMLINSOM, 2008; HALL, 2011) e algumas das produções britânicas, utilizam apenas o termo diferenciação (differentiation) (MCGARVEY, MARRIOT, MORGAN E ABBOTT, 2009). Os autores estudados fazem referência, ainda, aos termos ensino diferenciado e diferenciação do ensino, estes também relacionados à ideia de se trabalhar estratégias diversas na educação, seja por meio da utilização de métodos de ensino e/ou conteúdos e atividades diferentes, conforme as necessidades apresentadas pelos alunos, procurando sempre considerar o nível de desenvolvimento no qual eles se encontram para, a partir disso, fazer com que cada um avance em seu processo de aprendizagem. 
Os autores portugueses detêm boa parte dos escritos sobre o tema em estudo; percebese neles, inclusive, uma predominância do termo diferenciação pedagógica (CORTESÃO, 1998; PACHECO, 2008; COELHO, 2010; ROLDÃO, 2011; GOUVEIA, 2012).

Com relação às obras produzidas no Brasil, André (2006) e Mainardes (2007) utilizam o mesmo termo, diferenciação pedagógica, relacionando-o com a capacidade de utilizar estratégias diversas para fazer com que todos os alunos aprendam.

Há, ainda, os que trabalham o conceito de diferenciação pedagógica sem, no entanto, utilizar a expressão diferenciação. Dentre eles, é possível citar Marcel Crahay (2007), que defende a importância de se considerar as necessidades educacionais dos alunos, com o intuito de facilitar a aprendizagem e promover o êxito educacional. Ou seja, a ideia apresentada pelo autor condiz com os conceitos estudados, mas não está associada diretamente a eles.

O que se conclui com levantamento bibliográfico é que, não obstante o número de expressões utilizadas pelos autores pesquisados para se referirem à ideia de diferenciação pedagógica, todos os termos encontrados fazem alusão ao mesmo conceito, trazendo consigo a preocupação de se pensar e organizar o ensino de modo que seja possível proporcionar aprendizagens significativas a todos os alunos, combatendo e minimizando o fracasso produzido nas escolas.

Nesta pesquisa, optou-se por utilizar o termo práticas de diferenciação pedagógica. A escolha desta expressão justifica-se pelo fato de que o principal objetivo deste trabalho é o estudo de possíveis ações realizadas pelas instituições escolares e/ou por seus professores para diferenciar o ensino, proporcionando aprendizagens significativas a todos os alunos, a partir da consideração dos percursos de aprendizagem peculiares a cada educando.

\section{I.1 - As origens da diferenciação pedagógica}

Conforme já anunciado, é possível encontrar algumas referências sobre a diferenciação pedagógica no século XIX, em autores como Édouard Claparéde, John Dewey, Célestin Freinet, Robert Dottrens, pensadores cujas ideias compõem as teorias escolanovistas, que têm sua base na Pedagogia naturalista de Rousseau, representando o maior movimento de renovação do ensino após a criação da escola pública burguesa (GADOTTI, 1995). Ainda que os autores não se referissem aos termos relacionados ao conceito de diferenciação pedagógica, já se atribuía importância à consideração das diferenças no ensino muito antes do tema emergir nas discussões educacionais (CORTESÃO, 1998; PERRENOUD, 2000; GOMES, 2013). 
As ideias provenientes do movimento da Escola Nova fundamentam-se na atividade da criança e pautam o ato pedagógico na ação, propondo uma educação capaz de instigar a mudança social (GADOTTI, 1995). Tal corrente também defende que o centro do processo de ensino seja deslocado da figura do professor, fazendo com que cada aluno se torne um sujeito de suas aprendizagens.

Dentre os precursores da Escola Nova, atribui-se especial atenção ao trabalho do educador norte-americano John Dewey, que foi o primeiro a formular este novo ideal de ensino, afirmando que a educação deveria se dar pela ação, em detrimento do que pregava a pedagogia tradicional ${ }^{1}$. A educação, nessa perspectiva, seria entendida como um processo de descoberta pelo aluno, que deixaria de ser um receptor passivo de informações. De acordo com Roldão,

[...] é com John Dewey que o reconhecimento da natureza única do processo de aprendizagem de cada indivíduo se firma no plano teórico, ao colocar a ênfase do processo educativo no desenvolvimento pleno das potencialidades de cada indivíduo e de seu progresso constante. (ROLDÃO, 2003, p. 34).

Ao reconhecer que os sujeitos possuem características particulares de desenvolvimento, entende-se que os caminhos percorridos por eles, para alcançarem o sucesso em suas trajetórias escolares, também deverão ser únicos, de acordo com as necessidades inerentes a cada um. É por esse motivo que se afirma que a diferenciação pedagógica já despontava suas raízes nos teóricos escolanovistas, visto que diferenciar o ensino implica no reconhecimento das diferenças e, consequentemente, das diversas trajetórias educacionais passíveis de serem trilhadas pelos sujeitos, tal como preconizado pelas teorias supracitadas.

Outro educador do movimento escolanovista que contribuiu com o conhecimento das origens da diferenciação pedagógica foi o suíço Édouard Claparède. Seguindo diretrizes semelhantes às do trabalho desenvolvido por Dewey na Europa, Claparède foi um dos maiores expoentes da pedagogia da ação (GADOTTI, 1995) e é citado por vários estudiosos da pedagogia diferenciada como um dos primeiros autores a idealizar o que hoje se entende por este conceito.

Para Claparéde, a pedagogia deveria se basear no estudo da criança. Fundamentado em Rousseau, o autor entendia a infância como uma série de possibilidades criativas que não deveriam ser abafadas, conforme apontado por Gadotti (1995). O reconhecimento dessa diversidade de possibilidades trazidas pelas crianças sugere, consequentemente, a inclusão de

\footnotetext{
${ }^{1}$ 1. Por pedagogia tradicional, entende-se: o modelo pedagógico no qual o professor é tido como agente central do processo de ensino, considerado detentor do conhecimento a ser transmitido aos alunos que, por sua vez, são vistos como meros receptores do saber escolar.
} 
formas amplas de se desenvolver o trabalho educacional conforme o perfil individual de cada um, o que gera um indício do desenvolvimento de práticas relacionadas à diferenciação, nas escolas que seguiam a linha teórica desse autor.

Claparéde, assim como John Dewey, também defendia a ideia de que cada criança se desenvolve de modo particular. E, ao considerar essa especificidade, o autor afirmava que a educação deveria ocorrer de modo personalizado e não como uma "confecção em série" (GADOTTI, 1959, p. 124), discordando, assim como nas teorias de diferenciação, das práticas de cunho homogeneizador no ensino.

O caráter homogeneizador adotado pelas instituições educacionais foi, e tem sido, um dos maiores responsáveis pelo fracasso de muitos educandos, que, por não se adaptarem a certas práticas normatizadas pela escola ou por parte dela, acabam, muitas vezes, sendo vistos como maus alunos, desinteressados, preguiçosos, rebeldes, portadores de distúrbios, dentre outros rótulos, que são comumente utilizados para justificar os seus insucessos.

Reconhecer a importância da individualidade no processo de aprender de cada educando é uma premissa fundamental para se trabalhar a diferenciação pedagógica. Considerar o caráter peculiar que a aprendizagem assume para cada aluno é um dos primeiros passos na promoção de uma educação de qualidade para todos; ao se levar em conta que os seres humanos possuem ritmos e formas diferentes de aprender e se desenvolver, reconhece-se que uma educação única e padronizada para todos dificilmente será uma boa escolha, quando se fala em sucesso escolar. Se os alunos são diferentes entre si, é justamente o tratamento diferenciado, conforme as necessidades apresentadas, que irá permitir que todos possam alcançar o sucesso em termos de aprendizagem

Corroborando com essa ideia, Claparéde ressaltava que nenhuma sociedade "progrediu devido à redução das pessoas a um tipo único, mas sim devido à diferenciação (GADOTTI, 1995, p.154), alertando para a necessidade de se atentar às diferenças existentes entre os alunos, a fim de oferecer uma educação capaz de atender às necessidades de cada um, e garantir que todos tenham acesso e se apropriem do conhecimento oferecido pela escola.

A defesa de que os alunos possuem formas diferentes de se desenvolverem e, consequentemente, de aprenderem constitui uma premissa essencial da diferenciação pedagógica, visto que o reconhecimento dos interesses e das necessidades diversas, inerentes ao processo de desenvolvimento cognitivo individual, é um fator de grande influência na construção de um caminho de sucesso na trajetória educacional de cada um. 
Na mesma linha de raciocínio, Crahay (2007) também afirma que a tradição pedagógica francesa postula, desde Claparède, que quanto mais uma intervenção pedagógica for regulada pelo processo individual de aprendizagem, mais eficaz ela será.

Entretanto, é preciso ter cautela quando se fala em individualização do processo de aprendizagem, pois diferenciar o ensino não significa dar aulas individuais a tantos alunos quantos houver. Diferenciar o ensino, conforme já dito, é, em primeiro lugar, considerar as necessidades individuais de cada aluno para, baseando-se nestas necessidades, escolher as metodologias, as intervenções, as atividades que viabilizem a construção do caminho mais propício ao aprendizado de cada um, constituindo as trajetórias individuais de ensino, citadas por Perrenoud (2000) e que serão discutidas adiante.

\section{I.2 - A retomada do tema}

Não obstante a presença do conceito nas teorias escolanovistas, a ideia de um ensino diferenciado só começou a ser difundida, com maior vigor, a partir do momento em que o fracasso escolar passou a ser entendido como um problema pelas instituições educacionais.

O ensino oferecido dentro das instituições escolares nem sempre foi um direito estendido a todas as classes sociais. Segundo Cortesão (1998), a escola inicialmente era concebida com um funcionamento lento e trabalhoso, e atendia a um número muito restrito de alunos. Esses alunos compunham uma parcela seleta da população: os pertencentes às camadas mais abastadas da sociedade, que supostamente estariam interessados em adquirir um saber considerado inquestionável.

No entanto, chega um momento em que os cidadãos, especialmente aqueles que faziam parte das camadas menos favorecidas da sociedade, passam a reconhecer-se como sujeitos de direitos, e começam a lutar por eles. Segundo Bauer (2008),

[...] os direitos humanos, tal como são conhecidos hoje, foram fruto de evolução, sendo que o avanço nas discussões em torno deles sempre veio precedido de avanços no campo técnico-científico e após períodos históricos nos quais a dignidade humana foi extremamente desrespeitada, desconsiderada. (BAUER, 2008, p.558).

A partir destes movimentos de reconhecimento e reivindicação por direitos, passou-se a defender, também, que a educação seria uma condição básica para o desenvolvimento das nações; assim, a escola pública passou a abrir suas portas para todas as classes, saindo de um status de acesso mais restrito para tornar-se um direito de todos. 
Um dos marcos para que a educação fosse reconhecida como um direito de todos está na Declaração Universal dos Direitos Humanos, na qual consta no $1^{\circ}$ parágrafo do $26^{\circ}$ artigo que:

Artigo $26^{\circ} 1$. Toda a pessoa tem direito à educação. A educação deve ser gratuita, pelo menos a correspondente ao ensino elementar fundamental. $\mathrm{O}$ ensino elementar é obrigatório. O ensino técnico e profissional dever ser generalizado; o acesso aos estudos superiores deve estar aberto a todos em plena igualdade, em função do seu mérito. (DECLARAÇÃO UNIVERSAL DOS DIREITOS HUMANOS, disponível em http://www.ohchr.org/EN/UDRH/Documents_Translations/por.pdf)

O documento é claro ao afirmar que todos têm direito à educação e que essa educação deve ser gratuita, ao menos nas etapas fundamentais, o que pressupõe atendimento público, feito por parte dos governos ou por meio das instituições sem fins lucrativos. E, além de gratuito, o ensino elementar também deve ser obrigatório.

Com isso, tem-se que, além de ser reconhecida como um direito, a educação elementar passa a constituir uma prioridade a ser cumprida pelo governo, possibilitando a todos o acesso à escola, independentemente de sua classe social.

Embora o direito à educação esteja assegurado em documentos de nível internacional, como é o caso da Declaração Universal dos Direitos Humanos e seja tomado como obrigatório, Perrenoud (2000) afirma que "a posição de uma nação na competição mundial pode incitar a classe dirigente a democratizar o acesso aos estudos" (2000, p.39). Tal afirmação parece sugerir que, para além de se cumprir o que está escrito na lei, outros interesses poderiam motivar os governantes a universalizar o acesso à educação.

De todo modo, seja para cumprir a lei ou tendo outros interesses como motivação, a educação adquire o status de direito público subjetivo ${ }^{2}$, sendo democratizada em grande parte dos países existentes. A abertura da escola às classes menos favorecidas acontece, então, por meio das políticas de universalização do ensino, o que ocorre por volta do século XX, aproximadamente entre os anos 1950 e 1960 (CORTESÃO, 1998; PERRENOUD, 2000; GOMES, 2013), inclusive no Brasil.

Porém, com o decorrer dos anos, foram surgindo dificuldades que desafiaram a capacidade de resposta da escola às diversas exigências feitas pelo novo público que lhe compunha. Com a universalização do ensino, a escola, que anteriormente lidava com uma

\footnotetext{
${ }^{2}$ Por direito público subjetivo, entende-se: uma capacidade reconhecida ao indivíduo em decorrência de sua posição especial como membro da comunidade, que se materializa no poder de colocar em movimento normas jurídicas no interesse individual, cf. Duarte, 2004.
} 
camada mais homogênea da sociedade, teve que enfrentar o desafio de atender um grupo de pessoas muito maior e com características bem mais heterogêneas do que aquele com o qual estava acostumada.

No entanto, as instituições escolares não souberam atender de modo satisfatório às necessidades trazidas por este público que nela adentrava. A escola abriu suas portas e garantiu o acesso à população; no entanto, essa mesma instituição não garantia o êxito na aprendizagem, visto que não considerava as diferenças existentes entre os alunos. Por causa desta falha, muitos alunos começaram a fracassar, aprofundando as desigualdades existentes entre os que tinham acesso a uma boa escolarização e aqueles que eram dela repelidos.

Foram incorporadas parcelas da população que antes não tinham acesso à educação e cujas experiências culturais eram diferentes daqueles que antes constituíam o grupo de frequentadores da escola, ou seja, com o processo de expansão das oportunidades, a escola incorporou as tensões, as contradições e as diferenças presentes na sociedade. Oliveira e Araújo (2005) afirmam que a abertura da escola em si não acabou com as desigualdades, visto que garantir o acesso não significa que a educação ofertada será de qualidade.

Assim, a qualidade passa a constituir uma nova dimensão do acesso à educação. As formas de exclusão no interior da escola foram também objeto de análise de Dubet (2004). O autor afirma que, embora tenha universalizado o ensino, a própria escola produziu - e ainda hoje produz - formas de exclusão dentro de si. A escola pode promover a igualdade de acesso, mas isso não quer dizer igualdade de oportunidades, o que faz com que muitos fracassem.

Para que a escola promova uma competição justa, é preciso oferecer as mesmas condições a todos. Caso contrário, aqueles que não são favorecidos, seja por sua condição social, cultural, econômica, estarão sempre em desvantagem em relação aos demais alunos, estando fadados, em muitos casos, a fracassar em seu processo de aprendizagem.

Conforme já citado na Introdução deste texto, a escola havia estabelecido um padrão de aluno, considerado, conforme Roldão (2003) como um padrão médio. No entanto, ao estabelecer esse padrão, a escola negou as diferenças presentes entre os alunos. Aqueles que se enquadravam no ideal estabelecido pela escola eram considerados "bons alunos", os que se dedicavam, eram disciplinados, esforçados, interessados; aqueles que, de alguma forma, não se enquadravam no padrão estabelecido, ou seja, os que fugiam às normas da escola eram tidos como indisciplinados, desinteressados e rebeldes, aos quais era atribuída a culpa do próprio fracasso.

Todavia, o fracasso era recorrente entre os alunos das classes mais baixas porque, por pertencerem a meios diversos e terem culturas e interesses diferentes, muitos desses alunos não 
eram atendidos da forma que necessitavam; seus interesses não eram levados em conta e seus saberes eram, muitas vezes, desprezados. Dessa forma, esses alunos passavam a fazer parte de um processo de exclusão dentro da própria instituição escolar, o que lhes causava desinteresse e baixa autoestima, culminando, por conseguinte, no insucesso de muitos.

O interesse é uma alavanca para o aprendizado. Se o aprendente não se sente motivado pelo que lhe é exposto, se o saber aceito e ensinado pela escola é algo muito distante de sua realidade, dificilmente ele verá sentido naquilo. Além da questão do interesse, há que se considerar que as formas de desenvolvimento de cada aluno não são iguais. Todavia, a diferença nos ritmos e formas de aprender é vista, muitas vezes, como um problema, e não como um rol de possibilidades que o professor pode explorar para auxiliar o aluno em uma trajetória de sucesso.

As diferenças, na verdade, sempre existiram no seio escolar, mesmo quando o ensino ainda não era universalizado. Roldão (2003) aponta que, mesmo nas instituições mais seletivas, os alunos considerados diferentes eram classificados conforme suas diferenças - que muitas vezes eram entendidas, na verdade, como deficiências - e recebiam um tratamento diferente do habitual, oferecido aos alunos considerados normais. Essa foi umas das primeiras formas de diferenciação realizadas com o objetivo de se atender às diferenças existentes entre aqueles que tinham acesso à escola.

Ou seja, a diferença nunca foi bem aceita, mesmo quando eram as camadas mais abastadas que tinham acesso à escola. É muito fácil trabalhar com padrões e considerar que são os outros quem têm que se adequar. $\mathrm{O}$ trabalho que considera as diferenças tira a escola e seus agentes de sua zona de conforto, afinal, é muito mais engenhoso e demandante elaborar um plano de ensino, que atenda às diferentes necessidades dos alunos, do que estabelecer um plano geral para todos. Diferenciar o ensino gera desafios que não são facilmente superáveis e, muitas vezes, ações de acolhimento dos alunos provenientes de diferentes contextos e com diferentes histórias ficam fora do cotidiano escolar.

Roldão (2003) considera que o aumento do público que passou a ter acesso à escola fez com que a questão das diferenças, que antes era solucionada com a aplicação de medidas remediativas ou paliativas, começasse a se tornar um problema a ser enfrentado pela instituição escolar. Por conta da dificuldade da escola, em adequar as respostas de forma satisfatória, "enquanto instituição curricular, e dos professores, enquanto profissionais do currículo, às funções socialmente esperadas da escola" (ROLDÃO, p. 9, 2003), gerou-se o crescente fenômeno do fracasso escolar. 
É face a esse quadro de insucessos, presente na escola, que o conceito de diferenciação pedagógica passa a ganhar visibilidade, nos documentos de política internacional, na última década do século XX, os quais assumem a necessidade da melhoria da qualidade da educação diante de públicos tão diversos (ROLDÃO, 2003).

\section{I.3 - Diferenciação pedagógica: características essenciais de diferentes aportes}

Numa visão mais contemporânea, a diferenciação pedagógica tem sido discutida por vários autores. Embora existam produções nacionais (ANDRÉ, 2006; MAINARDES, 2007; 2009), a maioria das obras que discutem o tema estudado é de origem estrangeira. Dentre elas, encontram-se valiosas contribuições para o estudo do tema em Cortesão (1998), Perrenoud (1999, 2000), Tomlinsom (2000), Roldão (2003), Stoer, Magalhães e Rodrigues (2004), Crahay (2007), Pacheco (2008), Mc Garvey, Marriott, Morgan e Abbott (2009), Hall (2011), Gouveia et al (2012). A sistematização dos principais referenciais teóricos encontrados sobre a diferenciação pedagógica foi organizada da seguinte forma:

1. Aportes da literatura acadêmica portuguesa

2. Aportes da literatura acadêmica americana e inglesa

3. Aportes de Phillipe Perrenoud

4. Aportes brasileiros

- Literatura acadêmica

- Legislação Curricular Brasileira

5. Autores que trabalham a diferenciação de forma implícita

Os subitens a seguir apresentam as contribuições de cada perspectiva e, ao fim, é feita uma discussão sobre semelhanças e diferenças entre as perspectivas trabalhadas.

\section{I.3.1 - Aportes da literatura acadêmica portuguesa}

Ao que indica a revisão bibliográfica realizada neste trabalho, grande parte das produções que tratam do tema da diferenciação pedagógica está concentrada em autores portugueses, como: Cortesão, 1998; Roldão, 2003; Pacheco, 2008; Melo, 2011; Gouveia, 2012, Gomes, 2013.

De um modo geral, os autores portugueses começam a se preocupar com a diferenciação pedagógica a partir da discussão da universalização do ensino. Conforme cortesão: 
[...] os problemas de incapacidades, de insucessos cada vez mais intensos, cada vez mais evidentes, conduziram a que, posteriormente, se reconhecesse o peso e o significado da heterogeneidade real dos alunos que estavam ali, povoando, dando corpo, à instituição escolar, tornando cada vez mais difícil a aplicação das rotinas a que a escola se habituara. (CORTESÃO, 1998, p. 40).

Com base neste contexto educacional, o tema da diferenciação em Portugal surge da abordagem reconstrutiva do próprio conceito que se tem de currículo na atualidade, na medida em que ele se problematiza diante da diversidade de públicos existentes, de modo a garantir a melhor aprendizagem para todos, visto que a heterogeneidade de público era - e não deixou de ser, muito pelo contrário - uma marca muito forte dentro da sala de aula. A diferenciação do ensino constituiria, portanto, uma luta para que as desigualdades dentro da escola diminuíssem, ao mesmo tempo que as diferenças fossem valorizadas, tendo como consequência a elevação do nível de ensino.

Além de trazerem o contexto histórico da inserção da diferenciação pedagógica nas pautas educacionais, os portugueses abordam diversas formas de se colocar as ações de diferenciação pedagógica em prática.

Exemplificando essas ações, Roldão (2003) discute uma série de mudanças que devem ser feitas na escola com o intuito de estabelecer um trabalho diferenciado: a utilização de outras formas de agrupamento de alunos que não a classe; formas diferentes de abordar os conteúdos, que não os tradicionais métodos puramente expositivos, nos quais o professor expõe, aplica e verifica atividades cotidianas, em um ciclo que se repete constantemente; o abandono do conceito de "propriedade individual do professor sobre o espaço e o tempo da 'sua' aula" (p.56), abrindo espaço para organizações mais flexíveis; organização do trabalho dos alunos, do espaço e do tempo escolar, em formatos diversos, diferentes da organização tradicional das salas de aula, como por exemplo: pequenos grupos, pares, apresentações de professores e alunos, horas e tempos dedicados a atividades determinadas e a tarefas mais flexíveis (ROLDÃO, 2003).

A diferenciação pedagógica não deve assumir um caráter remediador; antes, precisa ter uma visão prospectiva, que considere que as medidas para se evitar o fracasso devem ser tomadas antes dele ocorrer, e não depois. Isso requer que a escola e os docentes se estruturem com relação aos diferentes modos de aprender de cada aluno, bem como ao modo de organizar situações de ensino, capazes de enquadrar as situações de aprendizagem na escola, devendo assumir um caráter de prática constante na sala de aula, e não mais de uma medida a ser tomada apenas nos casos de dificuldades extremas.

É importante ressaltar o papel que os professores assumem em uma perspectiva diferenciada de ensino, deixando de lado o caráter de detentores do conhecimento, para assumir 
uma posição mais flexível. Conforme Roldão (2003), os docentes são responsáveis pela disponibilização "consistente e organizada do saber científico e de modos de a ele aceder" (2003, p.56) e devem assumir o papel de tutores de grupos de alunos, orientando os percursos de aprendizagem individuais dos mesmos e as interações desenvolvidas na construção dos saberes.

Trata-se de uma mudança drástica de papéis, e por isso nem sempre é bem aceita, exatamente porque durante muitos anos o professor foi - e ainda é - visto como a figura máxima dentro de uma sala de aula. Esse é um dos pontos mais delicados da diferenciação pedagógica: a atuação do professor. É ele um dos maiores responsáveis pela diferenciação dar certo ou não, porque é ele, afinal, quem passa o maior tempo com os alunos, conhecendo-os como nenhum outro agente da escola, e possuindo uma ação indiscutivelmente determinante em seu sucesso.

Melo (2011) também traz contribuições a respeito da atuação dos docentes na diferenciação do ensino. A autora afirma que, para que a diferenciação se concretize, o professor deve delinear um plano de trabalho capaz de corresponder às especificidades da escola e da turma, envolvendo a própria criança na elaboração desse plano e permitindo que ela se sinta incluída no processo de aprendizagem. Ainda com relação à atuação docente, estes devem empregar esforços para que todas as culturas existentes nas suas salas de aula interajam entre si, devendo, para tal, evitar a manifestação de preferências culturais.

Na mesma linha das preferências culturais, Perrenoud (2000) afirma que é muito mais fácil que os professores simpatizem com os alunos que têm mais semelhanças com eles, do que com outros que estão mais distantes, o que é perigoso quando se fala em diferenciar o ensino, visto que o professor poderia enviesar sua atuação em prol de alguns e em detrimento de outros. Em suas palavras:[...] nas interações mais individualizadas, o professor é levado a reagir positivamente aos alunos mais polidos, mais inteligentes, mais simpáticos, mais bonitos, mais comportados [...] quando a distância interpessoal e intercultural é menor, a identificação é mais fácil, e o contato, mais estimulante (PERRENOUD, 2000, p.27).

Quando o professor age desta forma, automaticamente faz o que o autor (2000) chama de diferenciação involuntária, diferenciação essa que assume um sentido extremamente negativo no combate às desigualdades na escola, pelo fato de favorecer aqueles que possivelmente já são favorecidos. É por isso que os docentes devem ter a cautela de não deixar que tais preferências/semelhanças se manifestem na relação com os alunos, favorecendo alguns e desfavorecendo outros.

Todavia, Melo defende que "a escola deve criar em si mecanismos de discriminação positiva que permitam desenvolver o currículo de acordo com as situações dos alunos" (2011, 
p.31) corroborando com a ideia de que diferenciar o ensino é atender às especificidades dos alunos.

Promover a igualdade na escola, ao contrário do que muitos pensam, não é dar o mesmo tratamento a todos. Uma ação eficiente em termos de ensino e aprendizagem é aquela que oferece aportes diferentes, conforme as necessidades de cada um, sem, no entanto, reduzir as aprendizagens de um ou outro aluno, por considerar que o mesmo tem certas limitações e só atingirá um determinado patamar.

Gouveia (2012) também entende a diferenciação pedagógica como uma teoria de ensino baseada na premissa de que as abordagens instrucionais devem variar, além de serem adaptadas a alunos com características individuais - ou seja, que possuem o seu próprio jeito de pensar, de agir, de enxergar o mundo - em salas de aulas diversas.

[...] a diferenciação pedagógica compreende a prestação de um atendimento às necessidades de aprendizagem de um aluno em particular, ou de um pequeno grupo de crianças, contrastando com o modelo típico de ensinar todos os elementos de uma turma como se fossem todos iguais", tal como no modelo tradicional de ensino (GOUVEIA, 2012, p.104).

A autora também faz colocações com relação à atuação dos docentes em modelos diferenciados de ensino, observando que a diferenciação exige profissionais flexíveis em sua abordagem de ensino, capazes de adequar o currículo e a apresentação das informações aos alunos, em vez de exigir que os alunos se adequem ao currículo (GOUVEIA, 2012). No entanto, não basta que os professores sejam flexíveis para, de fato, serem capazes de diferenciar o ensino. É preciso que a escola ofereça apoio ao docente para a implantação de práticas diferenciadas, visto que, conforme aponta Perrenoud (2000), diferenciar o ensino não é uma tarefa fácil.

A diferenciação do ensino está estritamente relacionada com as questões curriculares. Ao mesmo tempo em que se defende a pluralidade de formas de ensinar e aprender, com a criação de diversos caminhos metodológicos e valorizando o interesse dos alunos por determinados assuntos, por exemplo, por outro lado é importante assegurar que todos tenham acesso a um rol mínimo de conhecimentos escolares sistematizados.

No caso, se um aluno porventura vier a mudar de escola, seja ela próxima ou distante de sua instituição de origem, que ele possa se situar em relação aos conteúdos aprendidos. É importante que todos os alunos adquiram os conhecimentos ditos essenciais. A questão que se coloca, portanto, é que o que deve ser diferenciado é a forma como os conteúdos serão adquiridos, de acordo com as possibilidades e necessidades de cada aluno, mas sem deixar de 
assegurar um mínimo de conhecimentos que deverão, sim, ser adquiridos por todos. Esses conhecimentos mínimos podem ser relacionados com o que Michael Young (2014) chama de conhecimento poderoso, questionando o que todos os alunos devem saber ao sair da escola (tradução nossa).

Dubet (2004), ao falar sobre a igualdade de oportunidades, de acesso e de condições, afirma que uma das concepções a respeito do que seria uma escola justa, consistiria no fato de que a escola deveria garantir a todos um mínimo de conhecimentos e competências. Assim, acredita-se que, mesmo provenientes de classes sociais diferentes e com características individuais próprias, os alunos sairiam da escola aptos para enfrentarem o mercado de trabalho de forma justa, em igualdade de condições. Constituir-se-ia, assim, uma forma de combate ao fracasso e, consequentemente, de insucessos em outras esferas da vida do aprendente, como a profissional, por exemplo.

Por outro lado, o autor alerta para o fato de que a garantia de conhecimentos mínimos a todos, por exemplo, poderia ocasionar problemas, como limitar a expressão dos talentos dos alunos, ao passo que "uma escola preocupada com a singularidade dos indivíduos age contra a cultura comum que uma escola deve transmitir e que também é uma forma de justiça” (DUBET, 2004, p. 540).

Na busca pela promoção da justiça escolar e, consequentemente, na tentativa de se garantir que todos aprendam, diminuindo o problema do fracasso nas escolas, deparamo-nos com questões bastante complexas, e até mesmo contraditórias. É por isso que o autor afirma, ainda, que na promoção da justiça escolar não existe uma solução perfeita, mas "uma combinação de escolhas e respostas necessariamente limitadas" (DUBET, 2004, p. 540). Cabe uma avaliação sensata, na hora de se tomar decisões na esfera educacional, a fim de se medir todas as vantagens e desvantagens de cada uma das soluções existentes, ponderando sempre para a escolha que melhor beneficie o aluno.

Mesmo tendo consciência das limitações inerentes às propostas de se fazer uma escola justa, capaz de lutar contra o fracasso, acredita-se que a diferenciação pedagógica possa se constituir como uma forma de promoção do sucesso escolar. Diferenciar implica o reconhecimento de que os alunos possuem linguagens, preferências de aprendizagem, interesses e conhecimentos variados, entendendo que, dentro de uma mesma classe existem vários estudantes, mas com capacidades diferentes.

Nesse sentido, a intenção de diferenciar o ensino é maximizar o crescimento de cada aluno, bem como o seu sucesso individual, atendendo a cada um no patamar onde se encontra, de modo a auxiliar seu processo de aprendizagem. 
Pacheco (2008) alerta para o fato de que diversificar o ensino não significa fazer uma mera individualização da aprendizagem, afinal, diferenciar não significa dar aulas particulares a cada aluno de uma turma. A diferenciação é entendida como "a reorganização das situações de aprendizagem face às capacidades, interesses e motivações dos alunos, mantendo uma estrutura básica de objetivos e conteúdos a que todos os alunos devem aceder" (PACHECO, 2008, P.181), ou seja, deve ser assegurado um currículo mínimo a todos os aprendentes.

Ao defender um modelo de desenvolvimento curricular processual, o autor explicita que a diversificação deve funcionar como um dispositivo de alteração de objetivos, conteúdos programáticos, atividades e avaliação em função das ofertas escolares e das necessidades educativas dos aprendentes, sem prejudicar o mínimo de conteúdos a serem aprendidos.

Diferenciar o currículo representa, ainda, aceitar mudanças nas práticas de ensino e na avaliação, "pressupondo que os alunos têm um mesmo percurso nas suas opções, mas que uns precisam seguir caminhos diferentes para que todos possam atingir o sucesso educativo" (PACHECO, 2008, p. 181). É neste sentido que se busca garantir o sucesso dos educandos no processo educativo, pois entende-se que todos devem ter acesso a uma cultura de base comum; no entanto, as formas que permitirão que esse acesso se concretize, é que serão moldadas conforme a necessidade de cada educando, seja por meio de metodologias diversas, organizações, atividades diferenciadas, etc.

Assim como Roldão (2003) e Gouveia (2012), Pacheco (2008) também traz exemplos de concretização da diferenciação pedagógica na escola. Em nível de currículo, ele defende a criação de uma liderança curricular que promova a coordenação horizontal ou a integração das atividades de ensino-aprendizagem pertencentes a uma turma ou a um departamento e/ou conselho de grupo disciplinar; defende agrupamentos flexíveis de alunos; a conjugação do trabalho do professor com os serviços e apoio pedagógico especializado com vistas ao sucesso educativo do aluno; e a articulação dos recursos e materiais curriculares.

Uma questão importante de ser ressaltada é que a diferenciação curricular não pode funcionar como um recurso de reforço da aprendizagem. Antes, "deve significar uma modificação referencializada, em termos de objectivos, conteúdos, atividades e avaliação, de um projecto curricular que se pretende direccionado para o sucesso dos alunos" (PACHECO, 2008, p.182), a saber, deve ser uma ação constante, e não remediativa.

A diferenciação pedagógica deve ser entendida como parte constante do processo de ensino e aprendizagem, compondo as práticas, as formas de agir, de organizar, de pensar, de discutir, de se apropriar dos conteúdos na sala de aula e não ser aplicada apenas quando se detectam certas dificuldades. $\mathrm{O}$ autor afirma, ainda, que: 
[...] a mudança que urge efetuar situa-se precisamente na proposta de construção de projetos curriculares que tornem possível a (re) construção do currículo em face das dificuldades diagnosticadas. Tal medida basear-se-á, com efeito, na desnormalização do processo de ensino-aprendizagem, ou seja, na concepção, desenvolvimento e avaliação de projetos curriculares ditados não pela situação de exceção, mas pelo imperativo de garantir um sucesso qualificado a todos os alunos. (PACHECO, 2008, p. 182)

Não se trata, portanto, de diferenciar de forma isolada. Antes, o processo de mudança inicia fazendo-se presente nos documentos que norteiam as práticas escolares, construídos por todos os seus agentes. A partir do momento em que a diferenciação é adotada como prática pedagógica da escola como um todo, as possibilidades de sucesso dos alunos aumentam consideravelmente.

\section{I.3.2 - Aportes da literatura acadêmica americana e britânica}

Os autores americanos e britânicos que discutem a diferenciação pedagógica trazem uma rica discussão, não só do viés conceitual, mas apresentam de forma extremamente detalhada o como fazer, ou seja, elencam diversos exemplos, explicando como desenvolver ações de diferenciação pedagógica na prática, os quais serão apresentados a seguir.

No âmbito das produções britânicas, Tomlinsom (2000) começa a discussão sobre as diferenças, partindo do pressuposto de que a maioria das salas de ensino elementar são compostas por três tipos de alunos: os que lutam para aprender; os que se desenvolvem com grande facilidade, ultrapassando até as expectativas esperadas para seu ano, e os que se encaixam em algum lugar entre esses dois primeiros grupos, ou seja, os alunos medianos. Embora a autora não use esse termo, é possível fazer uma relação com o aluno médio citado por Roldão (2003) no início deste capítulo.

Tal como defendido pelos autores portugueses, dentro de cada um desses grupos há que se considerar que os estudantes aprendem de formas variadas e têm interesses diferentes. Por isso, para que sejam atendidas as necessidades dessa população estudantil diversificada, muitos professores diferenciam - ou deveriam diferenciar - o ensino (TOMLINSOM, 2000).

A consideração da autora sobre os três tipos de alunos existentes em uma sala de aula, reflete uma preocupação em demonstrar que a diferenciação do ensino, em seu sentido mais puro e em suas diversas formas, tem como objetivo auxiliar a aprendizagem de todos; da mesma forma que um aluno pode se sentir desmotivado por não acompanhar sua classe, outro aluno também pode enxergar o processo de aprendizagem como algo totalmente enfadonho e 
desmotivador, por se sentir preso em um ritmo que está muito aquém do momento em que se encontra o seu desenvolvimento cognitivo.

É válido lembrar que a diferenciação não existe apenas para os alunos em dificuldade de aprendizagem. Aliás, ela não deve ser concebida desta forma; antes, deve auxiliar todos os tipos de alunos, presentes nos contextos heterogêneos das salas de aula. Alunos estes, que apresentam as mais diversas formas de aprender e se desenvolver, seja em um ritmo mais ou menos acelerado.

A individualidade do ser humano deve ser respeitada acima de qualquer padronização imposta por modelos escolares, sejam eles quais forem. Conforme aponta Heacox (2006) diferenciar o ensino significa "alterar o ritmo, o nível ou o gênero de instrução que o professor pratica, em respostas às necessidades, aos estilos ou aos interesses dos alunos" (HEACOX, 2006, p.10). Dessa forma, quando o professor reconhece as diferenças individuais, ele é capaz de estabelecer objetivos de aprendizagem baseados nas capacidades particulares dos alunos (HEACOX, 2006).

Heacox (2006) defende, ainda, que a diferenciação deve ocorrer nas escolas a partir da justificativa de que um mesmo "tamanho" não serve para todos. Conforme a autora:

As salas de aula diferenciadas refletem o diagnóstico consciencioso do professor sobre as necessidades de aprendizagem de seus alunos e o planejamento adequado das atividades e dos projetos que se dirigem à satisfação dessas necessidades. (HEACOX, 2006, p. 12).

Corroborando com este pensamento, Tomlinsom (2000) afirma que, para justificar a aplicabilidade das práticas de diferenciação na sala de aula, é necessário considerar as múltiplas formas de aprender e os variados interesses existentes entre os alunos. Neste sentido, a diferenciação consiste nos esforços dos professores em responder às diferenças entre os alunos em sala de aula; sempre que um professor estende às mãos no sentido de variar os esforços em prol de um indivíduo ou um grupo, para melhorar sua aprendizagem, ele está colocando a diferenciação em prática (TOMLINSOM, 2000).

Mais uma vez, é ressaltado o papel primordial do professor no êxito do desenvolvimento das ações de diferenciação pedagógica. Dessa forma, considerando os perfis, disponibilidade e interesses dos alunos, os professores podem diferenciar, pelo menos, quatro elementos na sala de aula: conteúdo, processo, produtos e o ambiente de aprendizagem (TOMLINSOM, 2000).

A diferenciação de conteúdos diz respeito àquilo que o aluno precisa aprender ou como ele terá acesso às informações, podendo ser feita com listas de materiais de leitura de diferentes níveis; com a utilização de listas de ortografia ou vocabulário de acordo com os níveis dos 
alunos; pela apresentação de ideias estudadas através de meios auditivos e visuais; com a criação de parceiros de leitura; fazendo reuniões com pequenos grupos para se reforçar uma ideia ou habilidade, no caso de alunos que apresentam dificuldades, ou para ampliar o pensamento ou as habilidades dos alunos que se encontram em níveis avançados.

A diferenciação de processos é definida como as atividades em que o estudante se engaja, a fim de dar sentido a um determinado conteúdo ou dominá-lo. Como exemplos de diferenciação neste nível, são citados:

a) a aplicação de atividades de diferentes níveis de dificuldade, suporte, desafio ou complexidade, mas que trabalhem os mesmos entendimentos e habilidades com todos os alunos; a criação de centros de interesse que incentivem os alunos a explorarem temas de interesse particular, em grupos menores;

b) o desenvolvimento de agendas pessoais, compostas por listas de tarefas escritas pelo professor - que contêm tanto os trabalhos comuns a toda classe, como o trabalho que aborde as necessidades particulares de cada discente.

c) o oferecimento de materiais concretos ou outros apoios para os alunos que deles necessitem;

d) a variação do tempo gasto pelos estudantes para o cumprimento de uma tarefa, proporcionando suporte tanto para um aluno, que tenha mais dificuldade e precise de mais tempo para completá-la, como para incentivar um aluno mais avançado no estudo de um tema com maior profundidade (TOMLINSOM, 2000).

A diferenciação ao nível dos produtos diz respeito aos projetos que têm como objetivo fazer com que o aluno ensaie ou aplique o que aprendeu em uma unidade de estudo. É a hora dos alunos mostrarem aquilo que aprenderam, momento que pode ser expresso das seguintes formas:

a) fornecendo, aos estudantes, opções de como expressar sua aprendizagem (por exemplo, apresentando os conteúdos em um teatro de fantoches, escrevendo uma carta ou desenvolvendo um mural, com etiquetas informativas sobre os conhecimentos adquiridos);

b) permitindo que os alunos trabalhem sozinhos ou em pequenos grupos em seus produtos de aprendizagem;

c) incentivando os alunos a criarem o seu próprio produto (TOMLINSOM, 2000).

A diferenciação do ambiente de aprendizagem diz respeito às formas possíveis de se trabalhar em sala de aula, de acordo com as necessidades de cada aluno. Dentre os exemplos de diferenciação no ambiente de aprendizagem, é possível citar: 
d) a existência de lugares na sala que permitam que se trabalhe de forma tranquila e sem distração, bem como lugares que incentivem à colaboração entre os alunos;

e) inclusão de materiais que mostrem a variedade de culturas e ambientes familiares aos alunos;

f) o estabelecimento de diretrizes claras para o trabalho independente, que correspondam às necessidades individuais dos alunos;

g) desenvolvimento de rotinas que permitam que os alunos obtenham ajuda, quando os professores estão ocupados com outros estudantes e não podem ajudá-los imediatamente;

h) compreensão de que alguns alunos têm a necessidade de se deslocarem mais para aprender, ao passo que outros aprendem melhor sentados e de forma mais calma (TOMLINSOM, 2000).

Quando se considera que os alunos possuem formas, interesses e ritmos diferentes de aprender, é de se esperar que, para que essas necessidades sejam atendidas, também as formas de resposta dadas pelos professores e pela escola como um todo devam ser diversas. Mais uma vez, a figura do professor aparece ocupando um lugar de destaque no desenvolvimento das ações de diferenciação.

Ainda dentro do contexto das produções americanas que tratam da diferenciação pedagógica, Hall, Strangman e Meyer (2002) oferecem contribuições importantes sobre como fazer a diferenciação na prática. Seguindo o pensamento de Tomlinsom (2000), as autoras abordam o conceito de instrução diferenciada, o qual obedece à mesma lógica da pedagogia diferenciada, citada pelos portugueses.

Partindo também do reconhecimento de que os alunos não são iguais, Hall, Strangman e Meyer (2002) defendem que diferenciar o ensino significa reconhecer que os alunos possuem linguagens, preferências de aprendizagem, interesses e conhecimentos variados e, por conta disso, as abordagens de ensino devem ser variadas e se adaptar em relação à individualidade do aluno. Além disso, também pressupõem a necessidade de se atribuir sentido às ideias no processo de ensino e aprendizagem (HALL, STRANGMAN \& MEYER, 2002, tradução nossa).

Assim, a intenção de se diferenciar a instrução é maximizar o crescimento e o sucesso individual de cada aluno, dentro de um contexto heterogêneo, de modo que cada educando esteja sempre diante de situações didáticas propícias para a sua aprendizagem, o que exclui situações que não trazem desafios ou que propõem uma missão fora do alcance (HALL, STRANGMAN \& MEYER, 2002).

Tal como nos autores portugueses, a análise dos autores americanos também evidencia que a diferenciação se relaciona de forma muito próxima com as questões curriculares. 
Considerando-se que a escola deve oferecer um rol de conteúdos mínimos a serem adquiridos por todos os alunos, constituindo uma base curricular comum, mas sabendo que esses alunos podem aprender de modos diferentes e trazem consigo interesses diversos, então, as formas possíveis de se diferenciar o ensino na sala de aula poderão atuar como facilitadores do processo de aquisição desses conhecimentos comuns na escola.

A diferenciação também está muito relacionada com as questões da didática e com o questionamento sobre o sentido do trabalho escolar, a relação com os saberes e a sua utilização; não se pode pensar nesse conceito sob um ponto de vista estritamente cognitivo. Para além desse aspecto, coloca-se a necessidade de que o aluno se sinta bem com o professor, visto que a distância entre a escola e os alunos é modulada, deliberada ou involuntariamente, pela maneira como os professores transitam pelo currículo e organizam seu ensino e a vida em sala de aula.

A diferenciação relaciona-se diretamente com questões de ordem didática porque, se as salas de aulas são formadas, em sua grande maioria, por públicos bastante heterogêneos, tornase imperativo que diversas formas de ensinar também sejam postas em prática. Neste sentido, a diferenciação das metodologias empregadas para se ensinar determinado conteúdo, por exemplo, é uma das formas que o professor pode utilizar para tentar fazer com que todos aprendam. Alguns alunos podem ter mais facilidade para entender certos conteúdos de forma mais tradicional, com uma explicação na lousa, seguida da resolução de exercícios; outros, por sua vez, terão mais facilidade de aprender com a utilização de um jogo, com uma brincadeira, com uma experiência.

Hall, Strangman e Meyer (2002) também afirmam que existem vários elementos e materiais utilizados no planejamento e implementação da instrução diferenciada, dentre os quais se incluem atos, conceitos, generalizações ou princípios, atitudes e habilidades a serem desenvolvidas com os alunos. As autoras também citam Tomlinsom (2000), afirmando que a instrução diferenciada pode ser feita em três diferentes níveis: currículo, processo e produtos, como visto no organograma a seguir: 
Figura 1 - Organograma dos níveis de diferenciação segundo Tracey Hall.

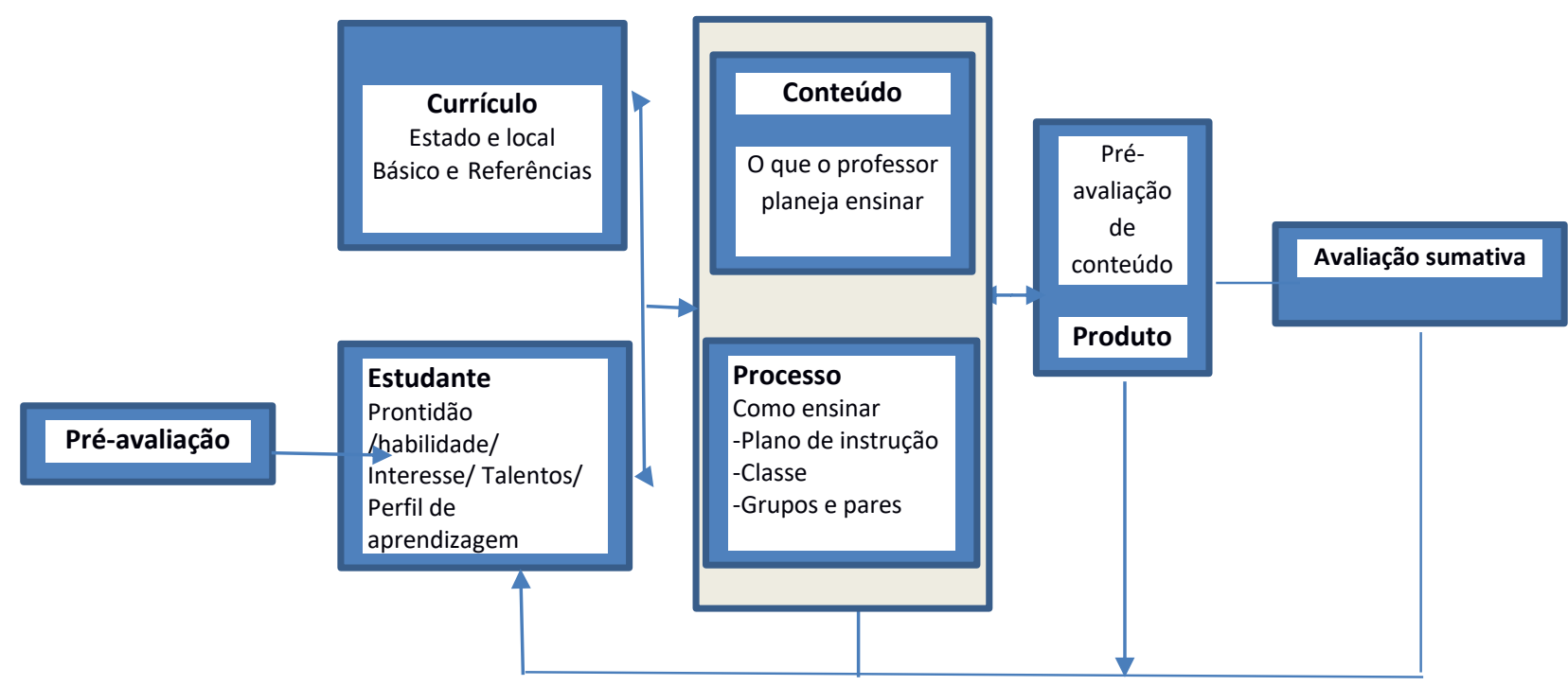

Fonte: Hall, Strugman and Meyer, 2002.

$\mathrm{Na}$ diferenciação de processos de ensino (process), as autoras reiteram que os alunos devem ser organizados em agrupamentos flexíveis, ou seja, não fixos. A intenção é permitir que os alunos interajam e trabalhem juntos no desenvolvimento de novos conteúdos. Os agrupamentos funcionam da seguinte forma: o professor realiza discussões introdutórias das ideias de um determinado conteúdo que se pretende ensinar; em seguida, os alunos são organizados para trabalharem em pequenos grupos ou de forma emparelhada, prosseguindo com o estudo desse conteúdo a partir da realização dos trabalhos e das tarefas a eles atribuídas (HALL, STRANGMAN \& MEYER, 2002).

Os alunos podem ser auxiliados uns pelos outros ou pelo professor para completar as tarefas. Para as autoras, os agrupamentos ou reagrupamentos de alunos são um dos fundamentos da instrução diferenciada, devendo ser um processo dinâmico, passível de se modificar, conforme o conteúdo, projeto, e as avaliações em curso. Essa forma de gestão na sala de aula beneficia tanto alunos, quanto professores. Para que a instrução diferenciada seja feita de forma eficaz, os professores devem selecionar com cuidado a organização e as estratégias de fornecimento dos conteúdos.

No que diz respeito à diferenciação dos produtos (products), as autoras fazem algumas considerações sobre a questão das avaliações. Elas afirmam que devem ser feitas avaliações iniciais com os estudantes, cujo papel é definido como de suma importância, pois a avaliação prévia dos conhecimentos, que os alunos têm ou não, é um fator determinante para conduzir a uma diferenciação bem ou mal-sucedida. No mais, além das avaliações iniciais, defende-se que 
sejam feitas avaliações contínuas, que possam fornecer um leque maior de escolhas e abordagens, que atendam às diferentes necessidades dos alunos (HALL, STRANGMAN \& MEYER, 2002).

Com relação a essas avaliações, elas tanto podem ter um caráter formal ou informal, incluindo-se, como instrumentos avaliativos, a realização de entrevistas, pesquisas, avaliações de desempenho, dentre outros (HALL, SRUGMAN \& MEYER, 2002). A instrução diferenciada possibilita um trabalho colaborativo e participativo na sala de aula, ao mesmo tempo em que o professor fornece um feedback constante aos educandos, capaz de orientar e reorientar as ações, conforme as necessidades dos alunos. Com isso, promove-se um maior aproveitamento nas aprendizagens e, consequentemente, elevam-se os níveis de sucesso escolar.

Com relação aos autores britânicos que falam sobre diferenciação, é possível citar as contribuições trazidas por Abbott (2001), Mc Garvey, Marriot, Morgan e Abbot (2009). Para começar a falar sobre a diferenciação, Abbott (2001) retoma algumas reformas curriculares ocorridas em países britânicos, a saber: a introdução do Currículo Nacional (National Curriculum), seguida pela Lei de Reforma da Educação (Education, Reform Act) em 1988 na Inglaterra e País de Gales e a Ordem de Reforma da Educação (Education Reform Order) em 1989 na Irlanda do Norte, as quais tiveram um grande impacto sobre os professores nas escolas e na prática de sala de aula.

Como exemplo, é possível citar a Ordem de Reforma da Educação (Education Reform Order) de 1989, na Irlanda do Norte, que forneceu um currículo comum que alegava ser "amplo, equilibrado, relevante e diferenciado" (ABBOTT, 2001, p.3, tradução nossa) e que oferecia oportunidades de progresso para todas as crianças, independentemente de sua capacidade. Com isso, as crianças teriam continuidade em sua experiência educacional, conforme suas necessidades individuais.

Tal como nas perspectivas americanas, o documento irlandês defende que, por causa das diferenças inerentes a cada aluno, o progresso e os níveis de desempenho dos sujeitos também deverá ocorrer em níveis e graus diferentes (ABBOT, 2001). Assim, justifica-se a adoção e execução de um planejamento de currículo diferenciado na escola.

Mesmo reconhecendo o quanto é difícil traçar um caminho que indique o papel central da diferenciação no ensino, reiterando que não há uma definição global de diferenciação, é possível agrupar as definições de diferenciação em, basicamente, três categorias: 
a) tarefas de harmonização para o aluno: definidas como a correspondência entre as atividades, recursos, metas de aprendizagem e as necessidades individuais dos alunos (STRADLING; SAUNDERS, 1993, apud ABBOTT, 1991);

b) acomodação das diferenças existentes entre os alunos mediante abordagens flexíveis: definida como a utilização de diferentes abordagens no ensino dos mesmos conceitos fundamentais do currículo, a fim de proporcionar o acesso ao conhecimento a uma gama maior de alunos. (MOSS, 1996, apud ABBOTT, 2001).

c) atendimento a todos os alunos, independente da capacidade: esta categoria entende que a diferenciação é baseada em uma compreensão das diferenças do indivíduo, e também do valor da aprendizagem de cada aluno. (BARTHORPE; VISSER, 1991 apud ABBOT, 1991).

Abbott (2001) afirma que é preciso planejar para se diferenciar o ensino, pois a falta de planejamento pode resultar em más ações de diferenciação. A implantação de atividades de diferenciação pedagógica deve ser feita com bastante cautela, além de demandar tempo de estudo e elaboração de planos e atividades a serem desenvolvidos com os alunos. A diferenciação, segundo este autor, é abordada sob uma perspectiva mais cognitivista, considerando que os indivíduos possuem capacidades diferentes, bem como formas de desenvolvimento e aprendizagem distintas. Dessa premissa vem a justificativa para se diferenciar o ensino: atender às necessidades de cada aluno, conforme o ritmo, a forma de aprender e as aptidões, de modo a proporcionar a todos o acesso aos conteúdos propostos na escola.

Em outra produção, Abbot, McGarvey, Marriot e Morgan (2009) partem do pressuposto de que "as crianças podem progredir em ritmos diferenciados, então a política da escola como um todo e os esquemas mais detalhados de trabalho devem garantir que a experiência de aprendizagem diferenciada seja proporcionada" (2009, p. 64). Mais uma vez, ressalta-se a questão do desenvolvimento particular de cada educando e, neste sentido, a diferenciação deverá ser empregada como forma de atendimento a todos os ritmos de aprendizagem peculiares a cada educando.

Os mesmos autores apresentam uma pesquisa realizada na Irlanda do Norte, na qual foram apontados aspectos da diferenciação através da investigação sobre como ela é planejada e aplicada nas escolas primárias do país, cujo objetivo foi identificar as questões-chave sobre diferenciação nas salas de aula do primário, para examinar em que medida a diferenciação e os benefícios associados a ela, e também os seus problemas, afetam diretores, coordenadores de área e professores, tendo como recorte de pesquisa o ensino das áreas de Ciências e Matemática. 
Os autores aplicaram formulários, com questões abertas e fechadas, para que pudessem captar as visões das escolas e das autoridades educacionais locais. Os resultados obtidos, segundo os autores, apontam para um entendimento da diferenciação como uma questão da escola como um todo, e não apenas como ações isoladas.

A pesquisa trabalhou com dados fornecidos por diretores, coordenadores pedagógicos e professores a respeito da visão que estes tinham sobre como o planejamento elaborado pela instituição era colocado em prática, nas salas de aula compostas por alunos com níveis diferentes de desempenho, tanto no desenvolvimento das atividades de sala de aula, quanto nas lições de casa.

Como resultado da pesquisa, os autores (MCGARVEY, MARRIOT, MORGAN \& ABBOTT, 2009) descrevem o quanto ainda falta para que os professores consigam aplicar os princípios da diferenciação, tais como a progressão e a continuidade nos estudos. Os resultados mostraram, também, que embora muitos professores tenham afirmado que compreendiam bem o significado de diferenciação, ainda necessitavam de ajuda para implementar esquemas de trabalho, capazes de proporcionar o atendimento adequado conforme os diferentes níveis de desempenho e aprendizagem, de acordo com desenvolvimento dos alunos (MCGARVEY, MARRIOT, MORGAN \& ABBOTT, 2009).

Considera-se que os aportes de literatura trazidos pelos americanos e britânicos, por serem os que explicam, de forma mais detalhada, como colocar a diferenciação em prática, constituem uma referência confiável para a elaboração de categorias de análise, a fim de se investigar as práticas de diferenciação no contexto em estudo.

\section{I.3.3 - Aportes de Phillipe Perrenoud}

O sociólogo suíço, Phillipe Perrenoud, é um dos principais autores contemporâneos que dissertam sobre o tema da diferenciação pedagógica ou, nos termos usados pelo autor, sobre a pedagogia diferenciada. Perrenoud, assim como os autores portugueses, faz um estudo minucioso acerca do fracasso escolar, e é a partir desse estudo que ele propõe a pedagogia diferenciada, como uma alternativa aos insucessos produzidos na - e pela - escola.

Conforme já citado na Introdução deste trabalho, o autor parte do princípio de que a falta de sensibilidade demonstrada pela escola, quando esta universalizou o ensino, fez com que ela começasse a avaliar seus alunos e concluísse, de modo unilateral - por considerar apenas a sua própria visão -, que alguns alunos simplesmente fracassavam, desconsiderando as 
diferenças existentes entre os grupos, e atribuindo o sucesso ou o fracasso unicamente ao esforço dos próprios educandos (PERRENOUD, 2000).

Para o Perrenoud (2000), a pedagogia diferenciada é entendida como uma pedagogia racional, na medida em que possibilita que todos tenham chances de aprender, seja qual for a sua origem e seus recursos culturais, devendo compor as práticas do professor dentro da sala de aula como uma constante do processo de ensino e das trocas ocorrentes na escola.

Seguindo uma linha de combate ao fracasso na escola, Perrenoud (2000) afirma que as pedagogias diferenciadas devem enfrentar o problema de como as crianças aprendem, além de lidar com a questão de como criar uma educação capaz de desenvolver uma relação menos utilitarista com o saber, promovendo instituições internas que atribuam sentido, de fato, ao trabalho escolar, visto que "a diferenciação está relacionada à didática e ao questionamento sobre o sentido desse trabalho, a relação com os saberes e com a sua utilização" (PERRENOUD, 2000). Assim sendo, deixa-se de atribuir o fracasso escolar exclusivamente à condição social do aluno, considerando-se que os processos que regulam a aprendizagem são de suma importância para que o sucesso desta seja possível.

O trabalho pedagógico, na perspectiva da pedagogia diferenciada, busca oferecer aprendizagens significativas a todos, abrindo, então, um novo leque de possibilidades aos alunos das classes mais baixas, em detrimento da lógica presente nas instituições escolares, que homogeneizava e naturalizava o fracasso dessa camada da população. Diferenciar o ensino, para o autor, pode ser definido como uma luta para que as desigualdades diante da escola se atenuem, ao mesmo tempo em que o nível de ensino se eleve (PERRENOUD, 2000).

Fica evidente na obra de Perrenoud que, embora também considere o fato de que a diferenciação do ensino deve atuar em prol de todos os alunos, o autor dispensa uma atenção especial aos alunos de classes mais desfavorecidas, por entender que estes tendem a fracassar mais na escola do que alunos pertencentes às classes média e alta.

Nesse sentido, é possível fazer conexões com o conceito de escola justa de Dubet (2004), que defende que a escola ofereça mais aos que tem menos, para que estes possam se igualar e ter chances de competir igualitariamente com alunos que já possuem um capital cultural mais denso. Essa ação, por si só, constitui uma forma de diferenciação no atendimento às necessidades dos diversos públicos que chegam às instituições escolares.

$\mathrm{O}$ autor alerta ainda para o fato de que, ao se falar em diferenciar o ensino, deve-se tomar o cuidado de não confundir diferenciação com individualização do ensino, prática que estaria mais ligada a uma noção de tutoria, o que não é a intenção da diferenciação pedagógica, que 
prevê a individualização de percursos. A diferenciação pedagógica, segundo o autor (2000), pressupõe:

a) concepção de progressões na aprendizagem durante vários anos, pressupondo-se ciclos de aprendizagem de dois ou três anos;

b) criação de agrupamentos de alunos, nos quais haja sentido de estabilidade, sem, no entanto, voltar à turma tradicional: grupos formados por alunos de idades variadas, grupos de projetos de interesse e grupos organizados conforme as necessidades comuns aos alunos;

c) concepção de instrumentos de orientação, que permitam seguir e orientar trajetórias individualizadas, decidindo o encaminhamento dos alunos a determinadas atividades ou grupos, conforme a necessidade.

O verdadeiro desafio na diferenciação pedagógica consistiria na criação de uma concepção de escola na qual, sempre que possível, o aluno fosse colocado em situações de aprendizagem fecundas para ele. No entanto, a diferenciação pedagógica não consiste apenas em criar essas situações ideais de aprendizagem e em individualizar os percursos de formação; mais do que isso, diferenciar o ensino pressupõe que sejam feitas transformações profundas na formação de professores, no espaço escolar, na estrutura do currículo.

Como exemplo dessas transformações, Perrenoud (2000) cita: o abandono da organização escolar em graus anuais, adotando-se as políticas de ciclos; a organização curricular por módulos de ciclos de aprendizagem; a adoção de políticas de formação contínua dos docentes.

Com relação à questão dos ciclos, Perrenoud define que "um ciclo de aprendizagem é um ciclo de estudos no qual não há mais reprovação” (PERRENOUD, 2004, p. 35). A não reprovação pode ser relacionada às práticas de diferenciação pedagógica nas escolas, na medida em que, respeitando-se os ritmos de aprendizagem e desenvolvimento dos alunos, não se justificaria a adoção de políticas deste teor nas escolas.

A adoção de uma política de ciclos requer mudanças drásticas dentro do meio escolar. e tanto a introdução desta política, quanto a inserção de ações de diferenciação nas escolas, são práticas que provocam receio entre os docentes. Em suas palavras, o autor afirma que:

[...] os ciclos de aprendizagem são sinônimos de profundas mudanças nas práticas e na organização da formação e do trabalho escolar; é uma verdadeira inovação, que assusta uma parcela dos professores e dos pais e requer novas competências. (PERRENOUD, 2004, p.12). 
Perrenoud alerta, ainda, que para as estratégias de diferenciação pedagógica serem desenvolvidas de modo eficaz, os ciclos devem ser longos: "dois anos, é claro, já é melhor que um só, mas ainda é um pouco curto para desenvolver estratégias de diferenciação eficaz”. (PERRENOUD, 2004, p.72).

Em resumo, Perrenoud (2000) afirma que a luta contra o fracasso consiste em dominar a individualização de percursos, de modo a deixar de favorecer os favorecidos e desfavorecer os desfavorecidos. Não basta praticar uma pedagogia diferenciada em uma turma tradicional, porque o domínio da individualização passa pela criação de dispositivos de acompanhamento e regulação da aprendizagem durante vários anos consecutivos, visto que as trajetórias se constroem em períodos longos (PERRENOUD, 2000). Portanto, a diferenciação é um trabalho contínuo em todo o processo de escolarização do aluno.

Mais uma vez, fica evidente a ênfase dada por Perrenoud ao atendimento dos alunos ditos desfavorecidos. Aqui, faz-se uma crítica à posição do autor, que embora cite que a individualização dos percursos, decorrente da diferenciação do ensino, deve ser um direito de todos os educandos, parece ter o foco voltado ao atendimento de alunos em condições de vulnerabilidade.

A diferenciação do ensino é muito mais do que o atendimento de alunos pertencentes às classes menos favorecidas, devendo ser entendida como uma ação didática a ser aplicada visando o sucesso de todos.

Sabe-se que a questão do fracasso escolar está mais presente em alunos de classes mais desfavorecidas social e economicamente, e os esforços para que essa camada da população tenha cada vez mais sucesso em suas trajetórias escolares devem ser empreendidos por todas as esferas políticas e não políticas, que lidam com a questão do ensino escolar.

Todavia, é necessário cuidado para não confundir a diferenciação do ensino como política exclusiva de combate às desigualdades sociais. Antes disso, ela é uma medida pedagógica, que visa o atendimento das necessidades cognitivas do alunado como um todo, considerando que as diferenças de capacidade existentes no ser humano devem ser respeitadas e atendidas adequadamente.

Se isto não ocorrer, não é só o aluno de classe "baixa" que irá fracassar, mas aqueles que pertencem a todas as camadas da população enfrentarão problemas com sua aprendizagem, visto que as diferenças fazem parte da constituição de todos os seres humanos, independentemente de sua condição social. 


\section{I.3.4 - Aportes brasileiros}

Nesta seção serão apresentadas as contribuições da literatura acadêmica brasileira e a análise de alguns documentos curriculares brasileiros, que teve por objetivo a busca de referências sobre a diferenciação nestes materiais.

\section{I.3.4.1 - Literatura acadêmica brasileira}

Conforme já citado na introdução deste trabalho, procurou-se conhecer o quanto o conceito de diferenciação pedagógica era estudado pelos autores brasileiros; para tanto, foram feitas pesquisas em busca de produções já desenvolvidas sobre o tema, no país. Como resultado, verificou-se que as produções brasileiras que discutem o tema da diferenciação pedagógica estão mais concentradas em André (2006) e Mainardes (2007). Os resultados detalhados das buscas, bem como dos caminhos utilizados, encontram-se no Capítulo II.Trilhas Metodológicas.

André (2006), organizadora da obra Pedagogia das diferenças na sala de aula, traz uma coletânea de textos que discutem a questão das diferenças escolares e a diferenciação pedagógica como alternativa ao trabalho educacional, os quais foram escritos, além de Marli André, pelas autoras: Laurizete Ferragut Passos; Maria Regina Guarnieri; Marta Maria Pontin Darsie; Neusa Banhara Ambrosetti; e Neusa Bertonni Pinto.

Vale destacar, nesta coletânea, o texto de André (2006), que traz uma discussão mais direta sobre a diferenciação pedagógica. Baseando-se nos escritos de Phillipe Perrenoud, a autora apresenta a diferenciação pedagógica como um conceito originado dos ideais da escola nova, que entendem que o aluno deve ser centro do processo educativo e o professor deve posicionar-se como um orientador, uma fonte de recursos e apoio. Conforme citado no texto:

\footnotetext{
As pedagogias diferenciadas assumem também os princípios das correntes construtivistas e interacionistas de que a aprendizagem ocorre através de um processo ativo de envolvimento do aprendiz na construção de conhecimentos, que decorrem de suas interações com o ambiente e com o outro. (ANDRÉ, 2006, p.19).
}

Tal como exposto no início deste capítulo, o trecho em análise também afirma que o conceito de diferenciação tem origem nos escritos dos precursores do movimento escolanovista, que defendiam uma educação construtivista, que como o próprio nome já diz, baseava-se na construção do conhecimento pelas mãos dos próprios educandos. 
Para André (2006) diferenciar o ensino é encontrar estratégias que possibilitem o trabalho com os alunos mais difíceis. Em suas palavras,

[...] se o arranjo habitual da sala de aula não funciona com esses alunos, se os livros e os materiais didáticos não são adequados para eles, se, enfim, as atividades planejadas não os motivam, é preciso modificá-las, inventar novas formas, experimentar, assumir o risco de errar e dispor-se a corrigir" (ANDRÉ, 2006, p.22).

Com essa afirmação, pressupõe-se que a diferenciação pode atuar como um caminho de tentativa e erro, de inovação, de riscos. Embora pareça um caminho inseguro e cheio incertezas, a decisão de trilhá-lo ou não poderá ser determinante para que um educando possa alcançar sucesso e ascender em sua trajetória escolar, ou se desiludir, de uma vez, a respeito da função da escola e do que ela poderia lhe proporcionar.

Com relação às formas de como concretizar a diferenciação, André (p.21, 2006) afirma que estas podem variar muito, considerando-se uma série de fatores, a saber: os recursos disponíveis na escola, o grau de liberdade que se tem para desenvolver o trabalho pedagógico, o tipo de instituição em que se trabalha, as condições de exercício docente, o apoio técnico disponível.

Para que a diferenciação pedagógica possa ser colocada em prática, a autora alerta para o fato de que é preciso vencer uma série de resistências e preconceitos, eliminando a crença de que alguns alunos seriam mais inteligentes do que outros, o que reforçaria a ideia de que o fracasso seria algo inevitável (ANDRÉ, 2006).

É justamente com a intenção de promover aprendizagens, de acordo com o ritmo de desenvolvimento de cada aluno, que se rebate a afirmação de que "uns seriam mais inteligentes do que outros". A diferenciação das metodologias, intervenções, materiais pedagógicos, atividades, dentre outras formas possíveis, que o conceito em estudo permite, é o que faz com que não se pratique a ação preconceituosa de classificar um aluno como "lento" ou como "acelerado demais", por reconhecer que, se é preciso diferenciar, é porque se admite que a diferença entre os alunos é perfeitamente aceitável e sadia.

Diferenciar o ensino é aceitar o desafio de que "não existem receitas prontas, nem soluções únicas" (ANDRÉ, 2006, p. 22). No entanto, a autora fornece algumas pistas sobre como diferenciar o ensino, defendendo a sua flexibilização e a abertura a pedagogias ativas, ou seja, que permitam que o aluno se envolva no processo de ensino e aprendizagem, como um sujeito que autônomo, que já traz consigo uma série de conhecimentos, que não podem ser 
ignorados pela escola; antes, devem ser incorporados ao seu processo de ensino para que este adquira sentido para ele.

Dentro da literatura brasileira sobre a diferenciação, também é possível encontrar contribuições de suma importância para se entender o conceito e sua aplicação nos escritos de Mainardes (2007). O autor parte da afirmação de que a diferenciação pedagógica considera que os alunos têm ritmos diferenciados de aprendizagem e, mais ainda, que todos são capazes de aprender, necessitando, portanto, que suas necessidades de cognitivas sejam atendidas (MAINARDES, 2007). É por meio da diferenciação que tais necessidades poderão ser atendidas, de modo que todos alcancem os objetivos propostos.

O autor defende a diferenciação de tarefas, conforme as necessidades dos alunos, afirmando que essa ação contribui com a criação de classes mais igualitárias, nas quais todos os alunos têm oportunidade de aprender, e não apenas os que são considerados bons pela escola (MAINARDES, 2007). No entanto, ele alerta para o seguinte fato:

[...] a proposição de tarefas diferenciadas não pode gerar na classe a ideia da existência de grupos mais atrasados ou mais fracos que os demais (estratificação da classe) ou o isolamento de alguns alunos ou grupo de alunos do coletivo da classe (MAINARDES, 2007, p. 3)

É nesse sentido que Perrenoud (2000) também defende que diferenciar não é dar aulas individualizadas a tantos alunos quantos houver, e que a diferenciação não pode criar grupos estratificados dentro da própria sala de aula. No que diz respeito à questão de como se diferenciar o ensino, Mainardes (2007) afirma que existem algumas possibilidades de diferenciação pedagógica, que podem ser feitas em sala de aula, dentre as quais é possível citar:

a) diferenciação por tarefas, onde são aplicadas tarefas de diferentes graus de dificuldade, conforme os níveis em que se encontram os alunos;

b) diferenciação por diferentes níveis de apoio e mediação: o professor busca oferecer mais atenção para alunos de forma individual ou em pequenos grupos, de acordo com a necessidade que se apresenta;

c) diferenciação pelo uso de diferentes recursos: o professor propõe a utilização de materiais didáticos diversos aos alunos;

d) diferenciação da organização da sala de aula: após a explicação dada pelo professor, os alunos são separados por grupos organizados, conforme as habilidades ou necessidades de aprendizagem, recebendo tarefas para serem realizadas em conjunto ou de forma individual. (MAINARDES, 2007). 
Como exemplo prático de diferenciação na sala de aula, o autor cita uma experiência realizada no âmbito da Universidade Estadual de Ponta Grossa, em pesquisa que tinha como objetivo analisar a implantação dos ciclos em uma rede municipal de ensino localizada dentro do Estado do Paraná.

$\mathrm{O}$ autor mostra que, com as observações realizadas no âmbito da pesquisa, ficou constatado que as atividades propostas nas salas de aula estudadas eram idênticas, fazendo com que em todas as salas observadas existissem alunos com dificuldades de aprendizagem (MAINARDES, 2007). De modo geral, dois grupos acabavam sendo prejudicados: o primeiro, composto por alunos para os quais as tarefas propostas eram consideradas muito fáceis; e o segundo, para o qual as atividades propostas eram muito difíceis.

Esta situação mostra, na prática, o que Roldão (2003) afirma sobre a escola ter concebido um aluno tido como "médio" em interesses e capacidades. A mesma situação acabava sendo reproduzida nas escolas da pesquisa realizada por Mainardes (2007), quando as atividades propostas atendiam apenas uma parcela dos alunos, fazendo com que apenas os alunos "médios", para os quais as tarefas estavam de acordo com o nível de aprendizagem, conseguissem progredir em seu processo educativo.

As salas de aula pesquisadas eram compostas por alunos alfabetizados, semialfabetizados e não alfabetizados, ou seja, eram espaços que agrupavam crianças que se encontravam em diferentes níveis de desenvolvimento, tendo, portanto, necessidades educativas diferentes umas das outras. Constatou-se, portanto, "que as salas de aula eram heterogêneas e a diferenciação de tarefas poderia ser uma alternativa viável" (MAINARDES, 2007, p.1), o que fez com que fosse proposta, pelos pesquisadores, a implantação de uma experiência diferenciada nas escolas pesquisadas.

O autor (2007) exemplifica, como uma das formas de se colocar a diferenciação pedagógica em prática na sala de aula, para que fossem atendidas essas necessidades, o desenvolvimento de atividades referentes a um mesmo contexto ou assunto, mas com propostas diferentes, conforme cada nível existente na sala. Este é um dos poucos exemplos concretos, de atividades de diferenciação pedagógica, encontrado na bibliografia estudada.

Um segundo exemplo relatado diz respeito a uma atividade de leitura. Após a leitura e exploração de um texto do livro didático, onde todos os alunos participaram, foram propostas as seguintes atividades: grupo I - (alfabetizados): interpretação do texto - atividades propostas no livro didático; grupo II - (semialfabetizados): leitura (em duplas) do texto do livro e, em seguida, os alunos deviam sublinhar as palavras com x, z, ch, lh, registrando-as no caderno; grupo III - (ainda não-alfabetizados): leitura em parceria (em duplas) do texto, mesmo que 
apenas os parágrafos iniciais. Durante a atividade, a professora ou o pesquisador ajudavam as crianças na leitura. As palavras que as crianças já identificavam eram registradas no caderno (MAINARDES, 2007, p. 10).

O autor ressalta a importância de se aplicar a diferenciação em salas de aula do ciclo de alfabetização, dada a importância da aquisição da leitura e da escrita no Ensino Fundamental I. Em suas palavras: “A garantia da apropriação da leitura e escrita, no menor tempo possível, precisa ser tomada como tarefa prioritária, principalmente nas classes onde já seria esperado que os alunos estivessem alfabetizados" (MAINARDES, 2007, p. 7).

No entanto, assim como afirma Perrenoud (2000), Mainardes (2007) também corrobora com a afirmação de que diferenciar o ensino não é uma tarefa simples. O autor considera que os professores precisam de "orientação, auxílio e estímulos permanentes" para enfrentar o desafio da diferenciação pedagógica $(2007$, p. 8). Dessa forma, reconhece-se que muito ainda precisaria ser feito, no sentido de conferir mais autonomia aos professores no desenvolvimento de um trabalho diferenciado, mesmo que já seja possível encontrar ações deste teor nas práticas de alguns docentes.

\section{I.3.4.2 - Legislação curricular brasileira e diferenciação pedagógica}

Conforme mostrou o levantamento teórico sobre o conceito de diferenciação pedagógica, não foi encontrado um número expressivo de produções de origem brasileira relacionadas ao tema da diferenciação.

Por esse motivo, buscou-se investigar a possível existência de referências à diferenciação pedagógica no âmbito de documentos educacionais brasileiros, tendo-se, por hipótese, que a existência destes indícios poderia embasar o desenvolvimento de práticas de diferenciação pedagógica por professores da rede pública, mesmo não havendo uma discussão sólida sobre esse tema entre os docentes e demais profissionais da educação.

Para esta análise, foram escolhidos alguns documentos curriculares importantes que regem a educação no país, produzidos nos âmbitos federal, estadual e municipal. São eles:

Diretrizes Curriculares Nacionais da Educação Básica

$>$ Parâmetros Curriculares Nacionais

> Orientações Curriculares da SME-SP - Secretaria Municipal de Educação de São Paulo. Portaria MEC Nº 826 DE 17 DE JULHO DE 2017 
Documento Orientador do PNAIC - Pacto Nacional pela Alfabetização na Idade Certa do ano de 2016

Os documentos foram analisados, de forma geral, com uma busca voltada aos aspectos mais relevantes para a pesquisa, atentando-se para a presença de elementos que fizessem referência à defesa do desenvolvimento e implantação de ações de diferenciação pedagógica. Os tópicos a seguir apresentam a análise de cada material.

\section{I.3.4.2.1 - Diretrizes Curriculares Nacionais da Educação Básica}

As Diretrizes Curriculares Nacionais da Educação Básica constituem um documento de caráter normativo obrigatório, criado com o objetivo de estabelecer princípios, fundamentos e procedimentos definidos pelo Conselho Nacional de Educação para orientar as políticas públicas educacionais, sendo responsável por orientar a organização, articulação, o desenvolvimento e a avaliação das propostas pedagógicas de todas as redes de ensino do Brasil.

No que diz respeito a possíveis menções sobre a diferenciação pedagógica, a leitura das Diretrizes Curriculares Nacionais mostrou que não há citações explícitas sobre o conceito estudado, bem como em relação à sua aplicabilidade às etapas para as quais esta norma foi elaborada. Porém, mesmo não havendo referências diretas sobre a diferenciação pedagógica ou acerca de outros termos a ela relacionados, foram encontrados alguns trechos que defendem uma forma de ensinar que considera os pressupostos de uma educação diferenciada.

[...] à riqueza da valorização das diferenças manifestadas pelos sujeitos do processo educativo, em seus diversos segmentos, respeitado o tempo e o contexto sociocultural. (BRASIL, 2013, p. 23)

Conforme apontado no trecho em destaque, o documento aponta a questão da consideração e da valorização das diferenças presentes entre os alunos, reiterando que os tempos individuais e o contexto ao qual cada aluno pertence devem ser respeitados na escola (2013). Tais aspectos coadunam com princípios basilares da diferenciação pedagógica encontrados nos escritos de Perrenoud (2000), Hall, 2002 e Roldão (2003), que também ressaltam a importância de se considerar os diferentes ritmos, formas de aprendizagem e a existência da diversidade sociocultural que permeia as escolas.

Em outro trecho, faz-se referência à questão dos percursos formativos, citados por Perrenoud (2000):

O percurso formativo deve, nesse sentido, ser aberto e contextualizado, incluindo não só os componentes curriculares centrais obrigatórios, previstos 
na legislação e nas normas educacionais, mas, também, conforme cada projeto escolar estabelecer, outros componentes flexíveis e variáveis que possibilitem percursos formativos que atendam aos inúmeros interesses, necessidades e características dos educandos. (BRASIL, 2013, p.26).

A utilização do termo "percurso formativo" também remete à ideia de se diferenciar o ensino, tal como visto nos escritos de autores como Perrenoud (2000) e Pacheco (2008), em que se aborda a questão da criação dos diferentes caminhos percorridos pelos alunos na aquisição de conhecimentos.

O documento também busca romper com a ideia de homogeneidade no ensino, defendendo que a escola deve assumir um caráter transgressor na forma de se atender aos alunos e de propor ações pedagógicas. Essa ideia está presente no trecho a seguir:

[...] é preciso fazer da escola a instituição acolhedora, inclusiva, pois essa é uma opção "transgressora", porque rompe com a ilusão da homogeneidade e provoca, quase sempre, uma espécie de crise de identidade institucional. (BRASIL, 2013, p.30)

A leitura realizada permite inferir que existem pontos de convergência com a teoria de diferenciação pedagógica nas DCN's, mas em nenhum trecho foram encontrados os termos utilizados nesta pesquisa para se referir ao conceito de diferenciação pedagógica.

Por esse motivo, não se pode afirmar que as Diretrizes Curriculares Nacionais para a Educação Básica no Brasil debatem o conceito de diferenciação pedagógica, tal como aparece nas discussões trazidas pelos autores estudados neste trabalho.

\section{I.3.4.2.2 Parâmetros Curriculares Nacionais}

Mais conhecidos como PCN's, os Parâmetros Curriculares Nacionais são documentos produzidos no âmbito da esfera federal que configuram uma "proposta flexível, a ser concretizada nas decisões regionais e locais sobre currículos e sobre programas de transformação da realidade educacional empreendidos pelas autoridades governamentais, pelas escolas e pelos professores”. (BRASIL, 1997, p.13)

Não se trata de um documento de caráter obrigatório a ser adotado pelas redes de ensino, mas assume a função de apoio às práticas curriculares na sala de aula, oferecendo orientações sobre os conteúdos a serem ensinados em cada etapa. Os PCN's, são considerados abertos e flexíveis pela natureza de sua produção, que pressupõe que sejam feitas adaptações para a 
construção do currículo de uma secretaria municipal ou, num nível menor, na construção do currículo de uma escola especificamente.

Os Parâmetros Curriculares Nacionais têm como função: subsidiar a elaboração ou a revisão curricular dos Estados e Municípios, dialogando com as propostas e experiências já existentes, incentivando a discussão pedagógica interna das escolas e a elaboração de projetos educativos, bem como servir de material de reflexão para a prática de professores. (BRASIL, 1997)

Além de propor os conteúdos a serem transmitidos nas diversas áreas disciplinares, os PCN's também oferecem subsídios para o desenvolvimento de práticas de organização dos conhecimentos, diferentes modos de abordagem dos conteúdos e exemplos de comportamentos a serem seguidos pelos professores nas mais diferentes circunstâncias, fornecendo auxílio às equipes de profissionais da Educação de forma geral, além de servirem como orientadores de formação docente. (BRASIL, 1997).

Mesmo reconhecendo as diferenças socioculturais existentes nos diversos contextos do país, os PCN's atribuem extrema importância aos conteúdos que são comuns a todos, de modo que tanto um aluno que resida no interior, como o que resida nas grandes cidades ou no litoral, tenham o direito de se apropriar desse conhecimento, direito esse que deve ser garantido pelo Estado.

Também se defende a adoção de uma base curricular comum a todos, entendendo que cada jovem ou criança brasileira deve ter acesso a um "conjunto de conhecimentos socialmente elaborados e reconhecidos como necessários para o exercício da cidadania para deles poder usufruir" (BRASIL, 1997, p.28).

[...] na medida em que o princípio da equidade reconhece a diferença $\mathrm{e}$ a necessidade de haver condições diferenciadas para o processo educacional, tendo em vista a garantia de uma formação de qualidade para todos, o que se apresenta é a necessidade de um referencial comum para a formação escolar no Brasil, capaz de indicar aquilo que deve ser garantido a todos, numa realidade com características tão diferenciadas, sem promover uma uniformização que descaracterize e desvalorize peculiaridades culturais e regionais. (BRASIL, 1997, p.28).

É a partir desta fala que o documento começa a reconhecer a existência das diferenças presentes entre os alunos, condição inicial para o desenvolvimento de práticas diferenciadas, mas sempre reiterando a importância do saber comum. 
E, da mesma forma que ocorre nas Diretrizes Curriculares Nacionais, esta legislação não faz também referências diretas às práticas de diferenciação pedagógica, não consolidando discussão sobre a temática.

\section{I.3.4.2.3 - Orientações Curriculares e Expectativas de Aprendizagem no Ensino} Fundamental Ciclo I - Prefeitura de São Paulo

Este documento foi selecionado para análise por ser uma produção da Prefeitura Municipal de São Paulo, cidade a qual a rede municipal estudada nesta pesquisa pertence, pressupondo que ele poderia conter indícios de defesa de práticas diferenciadas de ensino e embasar o desenvolvimento de possíveis ações diferenciadas por docentes desta rede.

As Orientações Curriculares de Aprendizagem e Expectativas de Aprendizagem no Ensino Fundamental foram elaboradas pela Diretoria de Orientação Técnica da SME - SP Secretaria Municipal de Educação de São Paulo, e fazem parte do Programa de Orientação Curricular do Ensino Fundamental, da Secretaria Municipal de Educação, tendo como objetivos: estabelecer um currículo comum, bem como propor as expectativas de aprendizagem para todas as escolas do Ensino Fundamental no ciclo I; contribuir para a reflexão e discussão sobre o que os estudantes precisam aprender, relativamente a cada uma das áreas de conhecimento; subsidiar as escolas para o processo de seleção e organização de conteúdos ao longo do Ensino Fundamental.

Foi feita uma análise geral, na qual buscou-se apreender a abordagem do conceito de diferenciação no material em análise, pois, conforme já citado, mesmo sabendo que a diferenciação é pouco discutida no Brasil, supunha-se que os documentos oficiais, que legislam sobre o tema no país, pudessem conter referências a essas práticas.

O estudo deste material evidenciou a discussão sobre as aprendizagens significativas, que não condizem com a ideia de transmissão linear de conhecimentos, considerando que o ensino e a aprendizagem devem se desenvolver de forma a constituir elos entre si:

Sabe-se que a aprendizagem significativa não se coaduna com a ideia de conhecimento linear e seriado. Conceber o conhecimento organizado linearmente contribui para reforçar a ideia de pré-requisitos que acaba justificando fracassos e impedindo aprendizagens posteriores. Numa concepção linear do conhecimento, o ensino e a aprendizagem funcionariam como cadeia de elos, na qual cada elo tem função de permitir acesso a outro (SÃO PAULO, 2007, p22). 
A afirmação de que a aprendizagem "não se coaduna" com a ideia de conhecimento linear e seriado está ligada à questão, dentro das pedagogias diferenciadas, de que os alunos possuem ritmos próprios de aprendizagem, não sendo, portanto, coerente que um mesmo conteúdo seja transmitido a um grupo de alunos ao mesmo tempo e da mesma forma, como ocorre nas pedagogias de cunho tradicional, que consideram a realização do trabalho pedagógico a partir de turmas homogêneas.

Assim como nos pressupostos da diferenciação pedagógica, nos quais se acredita que as formas tradicionais de organização educacional - que defendem um mesmo conteúdo sendo transmitido a um grupo de alunos ao mesmo tempo, assumindo a ideia de ensino linear e seriado - não são capazes de atingir todos os alunos em suas necessidades educativas, o trecho extraído do material em questão também defende que uma forma linear de organização do ensino não colabora com o sucesso nas aprendizagens, mas, ao contrário, acaba promovendo fracassos.

A análise realizada também evidenciou o reconhecimento de que os alunos possuem formas diferentes de aprender, e que estas diferenças individuais devem ser respeitadas, o que pressupõe a existência de caminhos diversos de aprendizagem:

[...] a aprendizagem não ocorre da mesma forma e no mesmo momento para todos; interferem nesse processo as diferenças individuais, o perfil de cada um, as diversas maneiras que as pessoas têm para aprender. Uma aprendizagem significativa está relacionada à possibilidade de os alunos aprenderem por múltiplos caminhos, permitindo a eles usar diversos meios e modos de expressão (SÃO PAULO, 2007, p. 21).

O trecho em destaque também vai ao encontro de pressupostos basilares da diferenciação pedagógica, visto que autores como Hall, Strugman e Meyer (2002) e Tomlinsom (2008), ressaltam o caráter único de aprendizagem inerente a cada educando, devido às diferenças inerentes a cada um.

Também foram encontradas referências que. Nos Cadernos de Orientação do ano de 2015 ,

Porém, tal como ocorre com a análise das DCN's e dos PCN's, nota-se que, neste documento, os excertos selecionados evidenciam a presença de ideias consonantes com os preceitos que a literatura acadêmica sobre diferenciação defende, mas sem trazer referências diretas sobre o conceito de práticas de diferenciação pedagógica. 


\subsection{Pacto Nacional para Alfabetização na Idade Certa - Portaria N$^{\circ} 826$ de} 17 de julho de 2017 e documentos orientadores do PNAIC

O Pacto Nacional para a Alfabetização na Idade Certa - PNAIC é um compromisso formal assumido pelos governos federal, do Distrito Federal, dos estados e municípios cujo objetivo é assegurar que todas as crianças estejam alfabetizadas até os oito anos de idade, ou seja, ao final do $3^{\circ}$ ano do ensino fundamental. A portaria $\mathrm{N}^{\circ}$ 826, de 17 de Julho, de 2017, apresenta as ações, diretrizes e ações de formação do Pacto Nacional pela Alfabetização na Idade Certa - PNAIC, no âmbito do Programa Novo Mais Educação - PNME, que foi criado pela Portaria MEC no 1.144/2016 e regido pela Resolução FNDE n ${ }^{\circ}$ 5/2016. ${ }^{3}$

Dentre as ações desenvolvidas, o PNAIC prevê formação docente para professores que atuam com classes de alfabetização, etapa que recebe atenção especial por parte das políticas públicas em educação no país, ressaltando a importância de se alfabetizar todos os alunos na idade correta, ou seja, até os oito anos de idade para alunos que estejam cursando o $3^{\circ}$ ano do Ensino Fundamental I.

A escolha dos documentos referentes ao Pacto Nacional para a Alfabetização na Idade Certa, nesta análise, ocorreu com a justificativa de que os preceitos da diferenciação pedagógica abarcariam princípios do processo de alfabetização, lembrando que o recorte adotado neste estudo foram os anos que compõem este ciclo.

Nesta portaria são abordados aspectos organizacionais do PNAIC, como: as atribuições de cada agente participante do desenvolvimento das atividades previstas; os aportes financeiros necessários, bem como as condições para pagamento de bolsas para os participantes das formações oferecidas; a previsão de formação continuada e o desenvolvimento de atividades de pesquisa no âmbito do programa; e as normas gerais para a participação no mesmo.

Este material, porém, não aborda questões de cunho pedagógico. Acredita-se que estas questões não tenham sido abordadas por se tratar de um documento explicativo e normativo acerca da instituição do programa. Por esse motivo, não foram encontradas quaisquer referências ao desenvolvimento de ações de diferenciação pedagógica no âmbito deste documento.

\footnotetext{
${ }^{3}$ O Programa Novo Mais Educação é uma estratégia do Ministério da Educação que tem como objetivo melhorar a aprendizagem em língua portuguesa e matemática no ensino fundamental, por meio da ampliação da jornada escolar de crianças e adolescentes.
} 
Também são discutidos aspectos referentes à gestão em 2016 e à formação dos professores e da equipe de gestão. Todavia, verificou-se que, assim como na Portaria $\mathrm{N}^{\mathrm{o}} 826 \mathrm{de}$ 17 de Julho de 2017, o conteúdo desse documento também tem sua atenção voltada aos aspectos organizacionais do programa, não se aprofundando em questões de caráter pedagógico, tampouco citando ou fazendo alguma referência ao conceito e à defesa de práticas diferenciadas de ensino.

A fim de complementar a análise da Portaria $N^{\circ}$ 826, de 17 de julho de 2017, optou-se por analisar alguns dos documentos orientadores do Pacto Nacional para a Alfabetização na Idade Certa. Foram escolhidos os documentos publicados para orientar as ações dos anos de 2015 (Currículo na perspectiva da inclusão e da diversidade: as Diretrizes Curriculares Nacionais da Educação Básica e o Ciclo de Alfabetização) e 2016 (Documento Orientador das Ações de Formação Continuada de Professores Alfabetizadores: PNAIC em Ação), período no qual foram realizadas as aplicações de questionários e as observações na escola de campo que permitiu a realização da pesquisa.

No documento do ano de 2015, Currículo na perspectiva da inclusão e da diversidade: as Diretrizes Curriculares Nacionais da Educação Básica e o Ciclo de Alfabetização, fica claro o reconhecimento das diferenças que permeiam o ambiente escolar:

Nossa problematização se coloca na impossibilidade de se pensar a escola no singular e, ainda, possível de existir alheia aos próprios processos de constituição de seus sujeitos praticantes (CERTEAU, 1994), isto é, como uma entidade absoluta [...] Essa visão fortalece a defesa que fizemos no início do texto, a saber, a de se pensar o currículo em sua complexidade, sendo diariamente tecido pelos educadores e pelos alunos em redes de conhecimentos com as quais convivem-atuam [...] (Brasília, MEC, SEB, 2015, p. 15).

Considerando essas diferenças e as possibilidades de construções curriculares diversas, o documento pressupõe uma perspectiva de alfabetização viabilizada por meio de diferentes percursos, de modo que todos possam ser atendidos em suas especificidades e, consequentemente, alcançarem o objetivo da alfabetização.

O Documento Orientador das Ações de Formação Continuada de Professores Alfabetizadores em 2016 PNAIC em Ação - 2016, possui ênfase voltada à formação dos professores participantes do programa:

Em muitos locais, a formação continuada dos professores alfabetizadores tem promovido significativas mudanças na aprendizagem das crianças e impactado positivamente no desenvolvimento profissional do professor, proporcionandolhe mais segurança, criatividade e autonomia. É importante que essas boas experiências possam ser aprofundadas, compartilhadas e disseminadas em todo o país. (Brasília, SEB, 20016, p. 4). 
Também são abordados aspectos relativos à heterogeneidade na sala de aula, além de se discutir os direitos de aprendizagem dos alunos com relação à alfabetização. Mais uma vez, evidencia-se a preocupação com a consideração das diferenças presentes entre os alunos, e a garantia de que alcancem êxito em suas aprendizagens.

Em síntese, verificou-se que as Diretrizes Curriculares Nacionais e os Parâmetros Curriculares Nacionais fazem referência às premissas que regem as ações de cunho diferenciado, defendendo a criação de ambientes propícios de aprendizagem, considerando que as salas de aula não são compostas de forma homogênea.

As Orientações curriculares e Expectativas de Aprendizagem no Ensino Fundamental Ciclo I - Prefeitura de São Paulo também defendem ações que estão de acordo com os princípios do conceito estudado, embora não haja menção explícita sobre a discussão e a defesa do desenvolvimento de práticas de diferenciação de ensino.

Com relação aos materiais do Pacto Nacional para a Alfabetização na Idade Certa, observou-se que os documentos orientadores trazem consigo algumas referências à defesa dos princípios de educação diferenciada. É citada a questão da formação dos professores e o trabalho com a diversidade dentro da sala de aula, que são aspectos primordiais no desenvolvimento de ações diferenciadas. Já a Portaria No 826 de 17 de julho de 2017 limita-se a dispor sobre os aspectos organizacionais que regem o programa em questão.

Vale ponderar uma questão comum a todos os materiais consultados: em que medida eles são, de fato, conhecidos pelos professores? Com que frequência e em quais momentos os docentes têm acesso a eles? Os Parâmetros Curriculares Nacionais definem, como um dos objetivos de sua criação, que essas leis sejam alvo de estudo em momentos de formação de docentes. Porém, os professores não parecem se apropriar, realmente, do conteúdo desses documentos, visto que as unidades educacionais trabalham muito pouco com legislações educacionais, em seus momentos de formação coletiva ${ }^{4}$.

Baseando-se nesta afirmação, e somando-se o fato de que as legislações consultadas não abordam o conceito de diferenciação pedagógica explicitamente, supõe-se que as produções oficiais não estão colaborando para embasar os docentes no desenvolvimento de possíveis práticas diferenciadas, tal como se imaginava no início desta análise.

\footnotetext{
${ }^{4}$ Essa afirmação foi feita com base na própria experiência da pesquisadora, que é professora na rede pública e, em três anos de atuação, não viu as legislações educacionais brasileiras serem foco de estudo em praticamente nenhuma das formações em serviço - e também externas - das quais participou.
} 


\section{I.3.5 - A diferenciação implícita no discurso}

Nem sempre as ações de diferenciação pedagógicas serão definidas com um termo específico. $\mathrm{O}$ estudo da literatura referente ao tema deste trabalho mostrou que existem autores que defendem a diferenciação do ensino sem, no entanto, mencionarem em suas produções os termos aos quais definem o conceito pesquisado. Entre eles, é possível citar as contribuições de Marcel Crahay (2007, 2013).

Em estudo publicado em 2007, o autor faz uma análise de várias pesquisas produzidas no âmbito educacional, que tinham por objetivo encontrar respostas sobre como lidar com os alunos em dificuldade escolar. Os estudos apontaram que, "de modo geral, as pesquisas indicam que a maioria dos alunos nada ganha com o afinamento das atividades de reforço ou com as pesadas estratégias de individualização" (CRAHAY, 2007, p. 204).

Crahay (2007) pontua que o professor enfrenta certas dificuldades na sala de aula, como, por exemplo, ter de lidar com um grande grupo de alunos, reconhecendo que, muitas vezes, o docente não consegue se desdobrar para atender a todos. Para contornar essa dificuldade, alguns pedagogos conceberam o que o autor chama de dispositivos de individualização (Crahay, 2007).

Esses dispositivos de individualização são compostos por fichas, jogos pedagógicos, materiais didáticos, e seu objetivo fundamental consiste em possibilitar ao professor que ele se aproxime, o máximo possível, de um ideal onde cada aluno possa progredir, conforme seu próprio ritmo, no domínio dos conteúdos ensinados. No entanto, o autor faz uma crítica a essa organização, afirmando que ela acaba causando uma redução do aspecto relacional do ato pedagógico, pois quando o aluno se confronta com os materiais, encontra-se em uma condição de aprendizagem solitária.

Como solução aos problemas trazidos pelos alunos em dificuldade na escola, anunciase que "os obstáculos mais frequentes à aprendizagem da maioria dos alunos podem ser superados com a ajuda de procedimentos leves" (Crahay, 2007, p 205). É preciso conhecer os problemas trazidos pelos alunos, para, então, conseguir estabelecer qual será a melhor forma de ajudá-los.

Ao falar sobre a finalidade da escola, Crahay (2013) define que esta deve ser o preparo dos alunos para a vida em sociedade, tornando-os capazes de enfrentar suas exigências. A escola assume, portanto, o papel de socializar e de educar, devendo ser uma instituição justa, que lute contra as desigualdades sociais presentes entre os alunos, "levando todos os indivíduos a adquirir os aprendizados fundamentais" (CRAHAY, 2013, p.13). 
Com base nesta concepção de pedagogia, que se preocupa em garantir que todos aprendam, o autor (2013) considera a necessidade de se prover mais atenção àqueles que possuem dificuldades mais significativas, e afirma que essa discussão conduziu à criação de três concepções de igualdade na pedagogia: igualdade de tratamento, igualdade de oportunidades e igualdade de aquisição. (CRAHAY, 2013).

A primeira concepção fala em assegurar a igualdade de tratamento no nível da educação básica. $\mathrm{O}$ autor aborda, neste caso, dois tipos de justiça: a justiça igualitária e a justiça distributiva. A primeira defende que cada um receba o mesmo que o outro, o que deveria ocorrer já no primeiro nível da escolaridade; oferecer-se-ia a todos, sem nenhuma distinção, a mesma educação. Com relação à segunda, a igualdade de oportunidades, esta consideraria as diferenças presentes entre os alunos, para então oferecer oportunidades mais igualitárias, conforme a necessidade de cada um (CRAHAY, 2013).

A consideração desses dois tipos de justiça defendidos pelo autor, por si só, já permite que se faça uma diferenciação do ensino: de início, oferece-se a mesma oportunidade a todos; depois, incluem-se as diferenças individuais, permitindo que cada aluno construa um percurso próprio por meio da justiça distributiva, que reconhece as necessidades individuais de cada um.

Com relação à igualdade de oportunidades, Crahay (2013) afirma que, se as crianças possuem aptidões diferentes, é função da escola identificar o potencial de cada uma, oferecendo oportunidades para que alcancem o máximo de seu progresso. Além disso, ela possui a responsabilidade de "eliminar os obstáculos geográficos, financeiros, institucionais, culturais e psicológicos que poderiam impedir que o indivíduo tivesse acesso ao nível de formação que é capaz de adquirir por ele próprio" (CRAHAY, 2013, p.14). É fundamental o papel da instituição escola na promoção de uma educação de qualidade, que não exclua seus membros por suas características diversas. Diferenciar o ensino é, pois, fazer com que todos recebam a mesma educação, mas por caminhos diferentes, conforme a necessidade existente em cada um.

Ao falar sobre a igualdade de aquisição, define-se que "o ensino deve ser organizado em função dos objetivos a serem alcançados por todos" (CRAHAY, 2013, p.16), considerandose que se alcançou o domínio de um assunto, se os critérios utilizados para definir a competência desejada forem satisfeitos. E, para que isso seja possível, Crahay (2013) afirma que as formas utilizadas, para se atingir a igualdade de aquisições, devem variar segundo as necessidades do indivíduo.

Nesse sentido, o autor (2013) afirma que:

[...] diferenciar o ensino pode ter dois sentidos diferentes. No primeiro, compatível com a ideologia da igualdade de oportunidades, considerar-se-á 
que é necessário tornar real uma escola sob medida, isto é, uma escola que ofereça oportunidades educacionais que sejam proporcionais aos talentos de cada um. No segundo sentido, consoante aos princípios da justiça corretiva, convém levar em conta a diversidade individual para conduzir cada aluno ao domínio dos objetivos definidos como fundamentais. (CRAHAY, 2013, p. 16).

A ideia de escola sob medida deriva do fato de se considerar que os alunos não são iguais, e que não aprendem todos da mesma forma; cada um é único em seu processo de aprendizagem, e possui suas estratégias, formas e ritmos particulares de aprender.

Porém, a consideração da "diversidade individual" não significa que o ensino será individualizado. Entende-se que o fato de se considerar as diferenças e fazer com que a aprendizagem se dê conforme o ritmo de cada aluno não quer dizer que o ensino será ministrado de forma particular, isolado de interações com os demais participantes do processo.

Crahay (2013) reitera que o fundamento dos debates relativos à escola possui caráter ético, e o tratamento das diferenças presentes na escola merece, mais do que nunca, a atenção dos professores, que devem promover discriminações positivas, que tendem a reduzir as desigualdades trazidas pelos alunos - sejam elas de ordem, social, econômica, cultural -, em detrimento das discriminações negativas, tal como quando a escola democratizou o acesso ao ensino, mas não atendeu às diferenças entre os alunos.

Quanto às formas de concretização dos princípios defendidos, o autor cita algumas ações, divididas categorias. Na primeira categoria incluem-se as seguintes ações: divisão das classes por nível e programas avançados para as crianças superdotadas.

Na segunda categoria, encontram-se: as zonas de educação prioritária; os programas compensatórios; as escolas de reforço destinadas às crianças das classes populares; avaliação formativa; práticas de tutelagem; aprendizagem cooperativa; e todos os demais mecanismos de apoio que tenham como objetivo ajudar os alunos que tenham dificuldades de qualquer ordem.

A diferenciação do ensino, portanto, assume um papel de importância, não só para os alunos em dificuldade escolar, mas também como um motivador, no caso dos alunos mais avançados. Assim, os alunos com mais dificuldade não se sentem deixados para trás, no processo de aprendizagem, tampouco os que possuem mais facilidade sentem-se brecados em seu processo de desenvolvimento, por terem de esperar os demais colegas de classe para prosseguirem. 


\section{I.4 Semelhanças e diferenças entre as diferentes perspectivas}

Um primeiro ponto a ser comentado diz respeito às diferentes formas encontradas na literatura para se referir às práticas de diferenciação pedagógica. Dados os autores estudados, que utilizam diferentes terminologias para se referirem à diferenciação pedagógica - ou, por vezes, nem utilizam termos específicos, como é o caso de Crahay (2007, 2013), que pouquíssimas vezes usa o termo diferenciação - um fato interessante, constatado na literatura consultada, é a relação existente entre o conceito de diferenciação pedagógica, a ideia a ele subjacente e às terminologias utilizadas para se falar da diferenciação pedagógica.

Muitas obras citam, diretamente, as expressões, diferenciação pedagógica, pedagogia diferenciada ou instrução diferenciada, por exemplo, para definir as práticas pedagógicas desenvolvidas no âmbito da escola e da sala de aula que, considerando as diferenças existentes entre os alunos, têm por objetivo dispor de recursos que facilitem o aprendizado de todos.

No entanto, em outras produções, ocorre o processo inverso: percebe-se que o autor faz referência ao princípio da diferenciação pedagógica sem, no entanto, utilizar os termos empregados na literatura para designar tais práticas.

Com base nas diferentes perspectivas apresentadas, percebeu-se que, de modo geral, os portugueses tratam a questão da diferenciação, sempre, a partir da questão fracasso escolar, entendendo-a como uma solução aos problemas de aprendizagem presentes na escola, e como prática imprescindível no combate às desigualdades escolares.

Já as perspectivas americanas e britânicas não citam tanto a questão do fracasso escolar, tendo como principal justificativa para se diferenciar o ensino, a questão das diferenças cognitivas entre os alunos. Isso não significa que os portugueses não estejam considerando a questão cognitiva. Mas o que predomina nos discursos portugueses é a questão do combate ao fracasso.

Encontra-se como preocupação comum em alguns autores, como Perrenoud (2000), Mainardes (2007) e Pacheco (2008), o alerta para que não sejam cometidos equívocos com relação à interpretação das práticas diferenciadas, salientando, por exemplo, que diferenciar não significa individualizar o ensino, onde cada aluno aprenderia de forma isolada e com um professor quase que exclusivo.

A defesa da organização da escola em ciclos está presente em boa parte dos autores estudados, como Perrenoud (2000), Roldão (2003), Pacheco (2008), Mainardes (2009). O modelo dos ciclos é defendido com a justificativa de se flexibilizar a organização do ensino, para que os alunos tenham mais tempo para desenvolverem suas aprendizagens, e como forma 
de diminuir as reprovações escolares, que conforme aponta Crahay (2007), não costumam ter efeito positivo na vida escolar daqueles que são retidos em um determinado ano.

Outro ponto semelhante diz respeito à forma de organização do trabalho na sala de aula. Tanto as perspectivas portuguesas, quanto as perspectivas americanas, inglesas, suíças (Phillipe Perrenoud) e brasileiras defendem a flexibilidade de agrupamentos de trabalho na sala de aula, seja por meio do trabalho colaborativo, em pares ou pequenos grupos, ou, ainda, no desenvolvimento de atividades individuais, o que permite que diversos arranjos possam ser feitos na sala de aula, em prol do desenvolvimento dos educandos.

Reconhecendo as formas de organização que prevalecem nos sistemas escolares, a saber, as formas mais tradicionais de ensino, as perspectivas estudadas apontam, de modo geral, que a diferenciação não é uma tarefa fácil para o professor (PERRENOUD, 2000; ROLDÃO, 2003; MAINARDES, 2007). De modo geral, os autores estudados defendem que o professor precisa de apoio da instituição escolar, como um todo, na execução das práticas de diferenciação pedagógica, seja por meio do fornecimento de materiais de trabalho, pelo oferecimento de cursos de formação continuada ou, mais ainda, na mudança da própria organização escolar.

Percebeu-se que, em todas as perspectivas estudadas, a diferenciação pedagógica é entendida como uma forma de combate aos insucessos na escola, constituindo uma organização coerente de trabalho em sala de aula; no entanto, não obstante o reconhecimento da importância dessas práticas, percebe-se que, em todas as perspectivas estudadas, são apontadas dificuldades no trabalho com as pedagogias diferenciadas.

De fato, atender às necessidades de todos os alunos não é uma tarefa fácil; é neste sentido que os autores defendem que, para além de se ter o apoio das instituições escolares nas mudanças das práticas em sala de aula, é necessário que os sistemas escolares, de modo geral, se reestruturem em função de uma organização mais flexível.

Mais uma vez, ressalta-se que o objetivo não é diferenciar para minorias ou para um ou outro grupo que apresente dificuldades específicas. É muito comum associar a diferenciação pedagógica apenas ao aluno com dificuldade, o que traz uma visão distorcida do conceito. $\mathrm{O}$ que se propõe com a diferenciação pedagógica é que esta seja uma ação constante, que faça parte do currículo, das práticas, das metodologias, da organização da escola como um todo.

Sendo entendido como uma ferramenta potencial na promoção do sucesso de todos, o ato de diferenciar o ensino será capaz de contribuir tanto com o sucesso do aluno com mais dificuldade, ao respeitar seu ritmo de aprendizagem e levar em conta suas dificuldades, como também irá favorecer o aluno que se encontra em um estágio mais avançado do conhecimento, ou até mesmo um aluno com superdotação. 
A diferenciação pedagógica deve ser adotada como uma metodologia institucional, uma forma de trabalho da escola em sua totalidade, e não só uma prática de um ou alguns professores. Obviamente que é o professor quem fará a maior parte das intervenções diferenciadas, visto que é dentro da sala de aula que os alunos passam mais tempo - e é com um professor que eles permanecem neste espaço.

Embora possam existir iniciativas isoladas de diferenciação por parte de alguns docentes, o ideal para que se concretizasse uma verdadeira ação de intervenção diferenciada seria que as escolas adotassem essa forma de trabalho como parte de sua concepção pedagógica institucional. 


\section{CAPÍTULO II TRILHAS METODOLÓGICAS}

Neste capítulo são apresentadas as trilhas metodológicas percorridas com vistas à concretização dos objetivos propostos pela pesquisa.

\section{II.1 - Método científico: escolha e consolidação de uma pesquisa de cunho qualitativo}

O início de um trabalho científico requer a definição de qual será o método mais adequado para um desenvolvimento satisfatório das ações planejadas em virtude dos objetivos definidos. De acordo com Minayo \& Minayo Gómes (2003) não há um método de pesquisa científica melhor do que o outro; um bom método é aquele capaz de conduzir o pesquisador ao alcance das respostas para suas perguntas.

No caso desta pesquisa, decidiu-se pela utilização da abordagem qualitativa, que permite que se identifique e analise, com profundidade, os dados de um determinado grupo de indivíduos em relação a um problema específico.

Dentro da abordagem qualitativa, existem vários tipos de pesquisa que podem ser desenvolvidos, tais como: estudos descritivos, estudos exploratórios, pesquisa etnográfica, análise documental, dentre outros. Entende-se que este estudo se enquadra nas vertentes exploratória e descritiva.

O estudo foi realizado considerando duas técnicas de pesquisa: a análise documental e a pesquisa de campo. Busca-se, assim, aliar, ao estudo bibliográfico e documental sobre as perspectivas de diferenciação pedagógica, presentes na literatura acadêmica e em documentos oficiais, o estudo do contexto escolar, explorando, a partir de observações e entrevistas, os aspectos que configuram a efetivação ou não das práticas de diferenciação pedagógica nas salas de aulas observadas.

\section{II.2 - Recorte de pesquisa}

Como anunciando na introdução deste trabalho, com relação aos anos de escolaridade aqui estudados, levou-se em consideração a importância do início do Ensino Fundamental, a saber, os $1^{\circ} \mathrm{s}, 2^{\circ} \mathrm{s}$ e $3^{\circ} \mathrm{s}$ anos. Tais anos adquirem relevância no contexto educacional por 
constituírem um momento crucial, basilar para toda a formação posterior do educando: a alfabetização. Supondo-se que o insucesso nestes anos pode acarretar problemas de aprendizagem ainda maiores nos anos ulteriores, escolheu-se como objeto de estudo o ciclo de alfabetização da rede municipal de ensino.

Com relação à disciplina a ser focada neste estudo, elegeu-se a Língua Portuguesa, dada a importância atribuída à alfabetização de um modo geral, mas com especial destaque aos discursos políticos em educação, especialmente com a adesão da rede municipal a programas como o PNAIC - Pacto Nacional para a Alfabetização na Idade Certa.

Além disso, considerou-se o fato de que nos anos pertencentes ao do Ciclo de Alfabetização as aulas são ministradas por professores polivalentes ${ }^{5}$. Por hipótese, isso favoreceria a gestão do tempo didático de modo a facilitar a incorporação da diferenciação pedagógica no cotidiano escolar, à medida em que este professor passa mais tempo com os alunos do que os professores especialistas, que são os que costumam lecionar apenas uma determinada disciplina.

\section{II.3 - O caminho inicial: levantamento bibliográfico e construção dos} instrumentos de pesquisa

A bibliografia que embasou a fundamentação teórica deste trabalho foi localizada a partir de buscas realizadas em plataformas científicas de pesquisa e os instrumentos elaborados para sua concretização foram construídos com base nesses referenciais.

Os subitens que seguem têm como objetivo apresentar como foi feito o levantamento e quais foram os resultados obtidos, bem como explicar a construção dos instrumentos utilizados no desenvolvimento das etapas empíricas da pesquisa.

\section{II.3.1 - Seleção e organização da pesquisa bibliográfica}

Para iniciar o estudo, foram realizadas buscas textuais que permitiram encontrar aproximadamente 76 referenciais bibliográficos, dentre os quais selecionou-se os mais pertinentes para a fundamentação teórica da pesquisa, ou seja, os que traziam explicações mais

\footnotetext{
${ }^{5}$ Ou seja, o mesmo professor leciona todas as disciplinas, com exceção de Arte, Inglês, Educação Física e Informática Educativa.
} 
elucidativas a respeito do que é e de como desenvolver a diferenciação pedagógica. Tais pesquisas resultaram tanto em obras produzidas no âmbito nacional, quanto a nível internacional. Também foram pesquisadas produções acadêmicas brasileiras em nível de mestrado e doutorado, que tratassem do tema estudado. Inicialmente, foram usados os seguintes descritores: diferenciação pedagógica; pedagogia diferenciada; práticas diferenciadas de ensino; instrução diferenciada, differentiated instruction.

Posteriormente, por sugestão da banca examinadora de qualificação da pesquisa, foram acrescentados outros descritores que poderiam estar relacionados às ações de diferenciação, com o objetivo de se obter mais informações para embasar o referencial teórico. São eles: trabalho diversificado, atenção à diversidade e classes homogêneas e heterogêneas. Todavia, as buscas com alguns destes descritores resultaram em trabalhos que fugiam do escopo do estudo, motivo pelo qual optou-se por não utilizá-los na bibliografia de base desta pesquisa

Foram consultadas as seguintes bases de dados: Biblioteca da Faculdade de Educação da Universidade de São Paulo, Google Scholar, Scielo - Scientific Eletronic Library On-line, UCL Library, Banco de Teses e Dissertações da Capes - Coordenadoria de Aperfeiçoamento de Pessoal em Nível Superior.

Os resultados obtidos por descritor em cada base pesquisada encontram-se no APÊNDICE deste trabalho ${ }^{6}$.

\section{II.4 - Elaboração de instrumentos}

Para a realização desta pesquisa foram criados os seguintes instrumentos: um questionário para ser aplicado aos docentes das classes do Ciclo de Alfabetização; um roteiro de entrevista para professores dos mesmos anos e um roteiro de entrevista para gestores educacionais (coordenadores, assistentes de direção e/ou diretores) e o roteiro de observação para a pesquisa de campo. Todos os instrumentos e roteiros de observação, utilizados na pesquisa empírica, encontram-se no APÊNDICE deste trabalho.

\footnotetext{
${ }^{6}$ As produções obtidas com a inserção dos descritores foram selecionadas conforme sua relação com o tema em estudo, visto que nem os todos os resultados obtidos tinham a ver com a diferenciação pedagógica. Por exemplo, ao se inserir o descritor pedagogia diferenciada, os sistemas de busca, na maioria das vezes, separam os descritores e retornam resultados relacionados com o tema da pedagogia no geral, sem considerar a palavra diferenciada, e vice-versa. Por esse motivo, foi feita uma seleção das obras que entrariam na composição do referencial teórico da pesquisa. O mesmo se aplica a todas as bases de dados consultadas.
} 
O questionário foi elaborado com o objetivo de apreender informações sobre formação e experiência profissional dos respondentes - conhecimento dos termos correlatos à diferenciação pedagógica, sondagem sobre aplicação de diversos tipos de práticas diferenciadas na sala de aula e sobre a frequência de desenvolvimento dessas ações, bem como a descrição das mesmas -, e, por último, coletar informações sobre a existência de alguma dificuldade, por parte do docente, para responder o questionário.

Esse instrumento foi pré-testado com professores do ciclo de alfabetização de uma unidade escolar pertencente à rede municipal de ensino, sendo alterado a partir das dificuldades encontradas, como será explorado posteriormente. O levantamento inicial foi utilizado com dois objetivos: um metodológico, à medida que as respostas dadas balizaram a escolha das escolas para a realização do trabalho de campo; e outro de exploração do conhecimento conceitual dos respondentes acerca da temática de interesse nessa pesquisa.

As entrevistas foram elaboradas para possibilitar a compreensão referente ao modo como docentes e escolas se organizam, para realizar as práticas de diferenciação pedagógica, declaradas nas respostas dos questionários. A versão do roteiro de entrevista elaborada para os professores foi organizada em dois blocos distintos: o primeiro teve como objetivo coletar informações sobre formação, experiência no magistério e na prefeitura e carga horária de trabalho, enquanto que o segundo contou com perguntas especificamente relacionadas à diferenciação

O roteiro de entrevista elaborado para coletar informações com os gestores educacionais também contou com dois blocos, sendo o primeiro idêntico ao da entrevista dos professores. $\mathrm{O}$ segundo bloco buscou compreender qual era o panorama geral da escola no trato com as diferenças cognitivas dos alunos, contemplando questões que captassem quais eram as diretrizes de trabalho adotadas que visavam à aprendizagem de todos. Questionou-se também, diretamente, quais seriam as ações de diferenciação pedagógica realizadas na escola, bem como as diretrizes emanadas da Secretaria Municipal de Educação para fomentar esse tipo de trabalho.

Cabe destacar que, ambos os roteiros de entrevista contaram com um terceiro bloco comum de questões, com os seguintes objetivos: obter informações sobre a existência de programa de reforço para os alunos; procurar saber sobre as diretrizes da escola, que embasavam a definição de conteúdos para cada ano; e buscar dados sobre as estratégias de planejamento e replanejamento do currículo, bem como outras questões que incidiam sobre a organização curricular da escola. 
O roteiro de observação foi dividido em três blocos: o primeiro teve como objetivo entender a forma de organização da sala de aula; o segundo buscou definir em que medida e como eram realizadas as ações de diferenciação pedagógica, no caso de existirem; e o terceiro teve como objetivo apreender como se dava a relação entre professores e alunos.

A criação tanto do questionário quanto do roteiro de observação foi desenvolvida tendo como base algumas categorias de análise, que remetem à classificação das ações que poderiam ser consideradas práticas de diferenciação pedagógica em diferentes tipos. Tais categorias são definidas no próximo item.

\section{II.5 - Categorias de análise}

As categorias de análise, utilizadas como referencial para a identificação das ações de diferenciação pedagógica, tanto nas falas dos entrevistados, como nas observações realizadas nas salas de aula, foram referenciadas nos trabalhos de Tomlinsom (2000), Hall, Strangman and Meyer, (2002) e Mainardes (2007). São elas:
a) Diferenciação de conteúdo/currículo
b) Diferenciação de práticas de ensino
c) Diferenciação de intervenção pedagógica
d) Diferenciação de atividades
e) Diferenciação de materiais
f) Diferenciação de expectativas de aprendizagem
g) Diferenciação dos produtos

Para cada categoria de análise foram estabelecidos indicadores que, como o próprio nome já diz, indicam ações condizentes com aquela forma de diferenciação pedagógica. Tais indicadores, apresentados a seguir, foram sistematizados com base no estudo da literatura sobre diferenciação pedagógica apresentado neste trabalho.

\section{Diferenciação de conteúdo/currículo}

Segundo Tomlinsom (2000), a diferenciação de conteúdos/currículo diz respeito àquilo que o aluno precisa aprender e como ele terá acesso às informações que lhe serão transmitidas. Podem ser consideradas formas de diferenciação curricular as seguintes ações: 
- O professor reúne pequenos grupos para reforçar uma ideia ou habilidade, no caso de alunos que apresentam dificuldades, ou para ampliar o pensamento ou as habilidades dos alunos que se encontram em níveis avançados.

- O professor ministra conteúdos diferentes para um aluno ou outro.

- A sequência do ensino de certos conteúdos é diferente para alguns alunos.

Vale ressaltar que ainda que este de indicador seja utilizado com base na teorização de Tracey Hall (2002), isso não quer dizer, necessariamente, que este tipo de diferenciação seja positivo, tendo-se em vista que diferenciar o currículo em relação a um ou outro aluno, poderia acarretar a diminuição do acesso ao conhecimento, o que não é um aspecto favorável quando se fala em igualdade dentro da escola.

\section{Diferenciação de práticas de ensino}

A diferenciação de práticas consiste nas diversas formas do professor agir em relação aos seus alunos, tendo em vista os diferentes perfis presentes em sala de aula. Podem ser considerados exemplos de diferenciação de práticas de ensino as seguintes situações:

- A atenção dispensada pelo professor aos alunos é diferente com relação a cada necessidade, sem que, no entanto, isso se configure como uma ação de discriminação negativa dentro da sala de aula.

- A forma de explicação de um determinado assunto muda se um aluno não entendeu o que foi dito pelo professor.

- O professor dispensa mais tempo com alguns alunos do que com outros, conforme as necessidades apresentadas.

\section{Diferenciação de intervenção pedagógica}

Tomlinsom, (2008) defende que uma das formas de se diferenciar o ensino é por meio da intervenção pedagógica. Essa prática ocorre quando o professor utiliza diversas formas de intervir no processo de aprendizagem dos alunos, conforme as necessidades apresentadas por eles. Portanto, são considerados indicadores desse tipo de prática no âmbito desse trabalho:

- O fato de o professor desenvolver formas diferentes de auxiliar os alunos quando estes encontram dificuldades em suas aprendizagens.

- Se uma tática não deu certo, o professor busca novas estratégias de auxiliar o aluno na aquisição do conhecimento. 


\section{Diferenciação de atividades}

Segundo Mainardes (2007) a diferenciação de atividades ou tarefas consiste na elaboração e aplicação de tarefas de diferentes graus de dificuldade, de acordo com os níveis de desenvolvimento em que se encontram os alunos. Com base nessa definição, podem ser considerados exemplos de ações de diferenciação de atividades:

- A aplicação de atividades referentes a um mesmo conteúdo, mas com graus de dificuldade diferentes conforme o nível dos alunos.

- A aplicação de atividades com comandas diferentes de acordo com o aluno.

- Se o professor sintetiza, muda, acrescenta atividades para alguns, e para outros, não.

- Se o professor trabalha com listas de materiais de leitura de diferentes níveis

- Se são utilizadas listas de ortografia ou vocabulário de acordo com os níveis dos alunos.

\section{$>$ Diferenciação de materiais}

A diferenciação de materiais consiste na aplicação de recursos diversos, tais como jogos, materiais específicos das áreas de Português, Matemática ou outras áreas do conhecimento, recursos multimídias em geral, dentre outros, utilizados com o objetivo de promover um entendimento mais efetivo dos conteúdos a serem aprendidos. São exemplos deste tipo de diferenciação:

- A utilização de diferentes tipos de materiais e/ou recursos pedagógicos (jogos, material dourado, letras móveis, dentre outros) na explicação dos conteúdos, para que haja maior entendimento do que está sendo ensinado e todos os alunos possam atingir os objetivos propostos.

- O manuseio de materiais pedagógicos diversos pelos alunos, durante a realização de atividades, com o intuito de promover experiências que possam satisfazer a todos.

\section{Diferenciação de expectativas de aprendizagem}

A diferenciação de expectativas de aprendizagem significa o quanto o professor espera de um aluno considerando o nível em que ele se encontra. Isso não significa que o professor deva exigir menos de um aluno e mais de outro, mas sim, que ele considere os momentos específicos em que cada educando se encontra em seu processo de aprendizagem para definir o 
que esperar ou não de cada um. Assim sendo, podem ser entendidas como diferenciação de expectativas de aprendizagem as seguintes situações:

- O professor diferencia o que espera que os alunos aprendam, conforme suas possibilidades, sem, no entanto, limitar o desenvolvimento dos mesmos?

- Há um plano na escola para diferenciar expectativas de aprendizagem para atender alunos com necessidades educativas especiais?

\section{Diferenciação de produtos}

A diferenciação de produtos, conforme apontado por Hall, Strangman and Meyer (2002), diz respeito às produções dos alunos sobre o que eles aprenderam acerca dos conteúdos ensinados. As autoras também dão um destaque especial para as questões avaliativas, considerando que devem ser feitas avaliações iniciais com os estudantes, a fim de se estabelecer os conteúdos prévios trazidos por eles, para definir um ponto de partida que favoreça a aquisição de conhecimentos. Constituem ações de diferenciação de produtos as seguintes práticas:

- O professor possibilita opções diferenciadas aos estudantes sobre como expressar sua aprendizagem (elaborando uma peça de teatro; desenvolvendo cartazes para apresentar os conteúdos à sala; elaborando murais informativos sobre os conteúdos adquiridos).

- O professor incentiva os alunos a elaborarem suas próprias criações, ou seja, seu próprio produto de aprendizagem.

- O professor permite que os alunos trabalhem sozinhos ou em pequenos grupos para confeccionarem produtos de aprendizagem.

\section{Análise conceitual da diferenciação pedagógica nos discursos docentes}

A análise conceitual dos discursos apresentados pelos docentes procurou compreender como os professores entendem o conceito de diferenciação pedagógica. Buscou-se apreender se havia embasamento teórico em suas falas, ou se elas se baseavam na relação que o professor estabelecia entre o conceito apresentado e sua própria prática em sala, sem que isso significasse que eles tiveram acesso aos estudos teóricos acerca do tema da diferenciação.

É importante ressaltar que as categorias de 1 a 7 foram utilizadas no questionário e no roteiro de observação de aula. 


\section{II.6 - Resultados do pré-teste}

O pré-teste da primeira versão do questionário foi realizado em uma escola de Ensino Fundamental I e II da rede municipal de ensino de São Paulo. Foram 4 os questionários respondidos por professores das classes de alfabetização: dois de professores de $2^{\circ} \mathrm{s}$ anos e dois de $3^{\circ}$ s anos.

Após a aplicação e análise das informações obtidas com o pré-teste do questionário, percebeu-se a necessidade de se fazer alterações no instrumento para que a captação de algumas informações pudesse ocorrer com mais clareza. Primeiramente, notou-se que alguns professores assinalaram lecionar em mais de um ano. Supõe-se que estes fossem docentes que assumiram outras funções na escola, que não a de regente de sala, como professores de recuperação paralela ou de sala de leitura, por exemplo.

Assim, para poder identificar com clareza o ano em que o professor lecionava introduziuse uma questão solicitando que o professor assinalasse a função exercida naquele ano: se regente de sala, professor de sala de leitura, professor de informática, professor de recuperação paralela etc.

Também houve a introdução de uma questão que procurava captar se os docentes já conheciam a prática de diferenciação pedagógica com outra nomenclatura, com o objetivo de saber quais outras expressões poderiam estar sendo utilizadas pelos docentes para se referir às práticas de diferenciação pedagógica.

Em relação aos resultados obtidos, de modo geral, foi possível perceber que as diversas expressões utilizadas para se referir ao conceito de diferenciação pedagógica não eram muito conhecidas pelas professoras que fizeram parte do pré-teste. Foram utilizados os seguintes termos: diferenciação pedagógica; pedagogia diferenciada; instrução diferenciada; e práticas diferenciadas de ensino. Apenas uma professora afirmou já ter ouvido falar do termo diferenciação pedagógica e duas afirmaram já ter ouvido falar do termo práticas diferenciadas de ensino.

No que diz respeito à realização das práticas de diferenciação em sala de aula, percebeuse que as professoras entrevistadas não possuíam conhecimento teórico sistematizado sobre estas ações, visto que não citavam autores, nem faziam apontamentos conceituais.

Mesmo aquelas que declararam desenvolver algum tipo de diferenciação na sala de aula, o faziam a partir da dedução do que é a diferenciação pedagógica. Houve casos, ainda, nos quais os professores faziam alguma relação do conceito com suas práticas, apenas quando lhes era apresentada uma definição conceitual sobre a diferenciação do ensino. 
Todas as professoras que responderam ao questionário afirmaram realizar todos os tipos de diferenciação, nele propostos, em suas práticas de sala de aula. O que variava, era a frequência com que as práticas eram realizadas. A diferenciação de conteúdos/currículo e a diferenciação de intervenção pedagógica foram os tipos realizados com mais frequência na prática das educadoras, segundo seus depoimentos.

De modo geral, as afirmações feitas pelas docentes, ao responderem sobre o que entendem por diferenciação pedagógica, ilustram que, do ponto de vista conceitual, não há um conhecimento aprofundado sobre o que é a diferenciação pedagógica, embora as definições dadas estejam, de certa forma, relacionadas com o tema.

Ao serem perguntadas sobre a frequência de aplicação dos diversos tipos de diferenciação pedagógica na sala de aula, percebeu-se que, mesmo os professores que afirmavam nunca ter ouvido falar de qualquer um dos termos apresentados, assinalaram realizar tais práticas em sala de aula. Isso parece indicar que o professor realiza um trabalho que atenta para as diferenças entre os seus alunos, no entanto, ele pode nunca ter ouvido falar das discussões e dos conceitos de diferenciação pedagógica.

Com relação à descrição das práticas de diferenciação desenvolvidas, percebe-se que as ações variavam muito de acordo com a professora. No entanto, duas professoras citam que as ações realizadas tinham como objetivo atender alunos em dificuldade. Segundo o depoimento de uma das respondentes, identificada como professora 3: “As atividades diferenciadas são aplicadas aos alunos com dificuldades que precisam de reforço e auxílio para desenvolver as atividades".

Nota-se, com esta fala, que a diferenciação, na prática da professora 3, parece estar assumindo um caráter remediativo, pois ela aplica as atividades diferenciadas, apenas no caso de alunos que apresentam dificuldades. E a intenção da diferenciação é auxiliar todos os alunos em seu processo de aprendizagem, e não apenas os que se encontram em dificuldades.

A última questão teve como objetivo verificar se houve alguma dificuldade em responder ao questionário. No geral, não foram relatadas dificuldades. Das quatro participantes, apenas uma faz considerações, afirmando que sua dificuldade foi com "alguns termos que ainda não tinha ouvido falar, apesar de aplicá-lo".

Os resultados obtidos com a aplicação dos questionários modificados nas Diretorias Regionais de Ensino serão descritos no Capítulo IV, bem como o relato e a análise das observações de campo. 
A entrevista elaborada para os docentes também foi submetida a um pré-teste, que ocorreu na mesma escola onde foi realizado o pré-teste do questionário, com uma das professoras que o havia respondido.

Após o pré-teste, verificou-se a necessidade de reestruturar o formato da entrevista, dividindo-a em três blocos, que sofreram as seguintes modificações: no primeiro, foram acrescentadas perguntas sobre a identificação e tempo de experiência do professor respondente; no segundo, que tratou das percepções docentes sobre a prática pedagógica e diferenciação, as perguntas foram organizadas de modo a ficarem mais elucidativas para o entrevistado, facilitando o entendimento e, consequentemente, permitindo a obtenção de respostas mais precisas para a pesquisa; por fim, o terceiro bloco foi criado para tratar de questões comuns às entrevistas de professores e gestores, cujo intento era captar informações sobre organização curricular e planejamento pedagógico. 


\section{CAPÍTULO III}

\section{EXPERIÊNCIAS DE CAMPO: DESCRIÇÃO, CONTEXTUALIZAÇÃ̃ E ANÁLISE}

Neste capítulo são descritas e analisadas as experiências empíricas desenvolvidas no decorrer da pesquisa: aplicação de questionários nas Diretorias Regionais de Ensino, observações de campo e entrevistas com professores e gestores, que permitem apreender os distintos significados que a diferenciação pedagógica assume nos discursos e nas práticas dos profissionais que atuam na escola visitada.

\section{III.1 - Aplicação dos questionários e análise dos resultados nas Diretorias Regionais de Ensino: Butantã, Ipiranga e Itaquera}

Conforme apresentado no Capítulo III, realizou-se um pré-teste dos instrumentos utilizados na pesquisa de campo em uma escola de Ensino Fundamental I, a fim de verificar a adequação dos mesmos para a captação das informações necessárias à pesquisa.

Após o pré-teste, foi feita a aplicação do questionário em três DREs: Butantã, Ipiranga e Itaquera ${ }^{7}$, que ocorreu em espaços de formação de professores atuantes nos anos do Ciclo de Alfabetização, que são os $1^{\circ} \mathrm{s}, 2^{\circ} \mathrm{s}$ e $3^{\circ} \mathrm{s}$ anos do Ensino Fundamental I. O saldo de respostas obtidas em cada um foi o seguinte:

DRE Butantã: 17

DRE Ipiranga: 48

DRE Itaquera: 37

Somando-se as três DREs, ao todo, 102 docentes responderam o instrumento. A sistematização dos dados obtidos foi feita por meio de planilhas de Excel, nas quais os respondentes foram classificados conforme a DRE e o ano lecionado. A cada respondente foi atribuído um código de identificação ${ }^{8}$. Os resultados foram sistematizados em tabelas, analisadas na próxima seção.

\footnotetext{
${ }^{7}$ Inicialmente a previsão era aplicar o questionário em quatro diretorias regionais. Uma delas, no entanto, negou a realização da pesquisa.

${ }^{8}$ No caso da DRE de Itaquera, por exemplo, para os professores de $1^{\circ}$ ano, utilizou-se o código Ita1, que é o código da DRE e o ano lecionado. Ao lado de cada código, acrescentou-se número do respondente/questionário (Ita1_1; Ita1_2; Ita1_3).
} 


\section{III.2 - Análise dos resultados dos questionários}

Em relação à função exercida pelos docentes, dos 102 participantes, 98 eram professores titulares, ou seja, detinham a regência de uma sala de aula, estando com os alunos todos os dias (Tabela 1).

Tabela 1 - Funções docentes dos professores que responderam ao questionário

\begin{tabular}{lcc}
\hline Função & $\mathbf{N}$ & $\mathbf{\%}$ \\
\hline Professor titular & 98 & 96,1 \\
Professor de sala de leitura & 1 & 1,0 \\
Professor CJ/Módulo & 3 & 2,9 \\
Total & $\mathbf{1 0 2}$ & $\mathbf{1 0 0 , 0}$ \\
\hline \multicolumn{2}{c}{ Fonte: Base de dados da pesquisa. Organização da autora. }
\end{tabular}

Dos demais respondentes, um era professor de sala de leitura e três eram professores CJ (complementação de jornada), também conhecidos na rede municipal por professores do módulo. O professor CJ ou do módulo é aquele que ficou sem regência na atribuição de aulas, seja por falta de turmas ou por opção própria, abstendo-se da escolha de sala e passando a vez para o próximo na escala de docentes da unidade escolar em que é lotado.

Usualmente os professores regentes lecionam as disciplinas de Português, Matemática e Natureza e Sociedade - denominação utilizada para abordar os conteúdos de Ciências, Geografia e História - sendo comumente chamados de professores polivalentes. As demais disciplinas, como Inglês, Arte e Educação Física são ministradas por professores especialistas, ou seja, aqueles que cursaram licenciaturas específicas dessas áreas do conhecimento. Tais profissionais, contudo, não foram objeto de estudo da pesquisa.

Com relação aos anos em que os professores lecionavam, dos 102 respondentes, 36 atuavam no $1^{\circ}$ ano; 30 no $2^{\circ}$ ano e 35 no $3^{\circ}$ ano, conforme aponta a tabela 2 :

Tabela 2 - Ano de atuação dos respondentes

\begin{tabular}{ccc}
\hline Ano & N & \% \\
\hline Resposta inválida & 1 & 1,0 \\
1o ano & 36 & 35,3 \\
2o ano & 30 & 29,4 \\
3o ano & 35 & 34,3 \\
Total & $\mathbf{1 0 2}$ & $\mathbf{1 0 0 , 0}$ \\
\hline
\end{tabular}

Fonte: Base de dados da pesquisa. Organização da autora. 
Com relação à formação inicial dos docentes, a tabela 3 mostra que dos 102 respondentes, aproximadamente $67 \%$ possui formação de nível Superior em Pedagogia. A formação de nível médio, que corresponde ao curso de Magistério, é indicada por $25 \%$ dos participantes da pesquisa.

Tabela 3 - Formação inicial dos respondentes

\begin{tabular}{llc}
\hline \multicolumn{1}{c}{ Formação inicial dos respondentes } & N & \% \\
\hline Magistério & 26 & 25,5 \\
Pedagogia & 68 & 66,7 \\
Licenciatura + Complementação pedagógica & 40 & 39,2 \\
Apenas Complementação pedagógica & 17 & 16,7 \\
\hline \multicolumn{2}{r}{ Fonte: Base de dados da pesquisa. Organização da autora. }
\end{tabular}

Outra formação observada foi a daqueles que inicialmente haviam feito um outro curso de licenciatura e, posteriormente, uma complementação na área da Pedagogia, por este ser um requisito na rede municipal de São Paulo para se lecionar no Ensino Fundamental I. Possuem esta formação 40 dos 102 respondentes, o que equivale a aproximadamente $40 \%$ do total de participantes.

O Plano Nacional de Educação - PNE - que vigorou de 2001 a 2011 estabelecia como uma de suas metas que, a partir de sua data de vigência, somente deveriam ser admitidos, nas redes municipais, docentes que possuíssem a formação estabelecida no art. 62 da Lei de Diretrizes e Bases na Educação Nacional - LDB, a saber:

Art. 62. A formação de docentes para atuar na educação básica far-se-á em nível superior, em curso de licenciatura plena, admitida, como formação mínima para o exercício do magistério na educação infantil e nos cinco primeiros anos do ensino fundamental, a oferecida em nível médio, na modalidade normal. (Redação dada pela lei no 13.415 , de 2017).

As exigências previstas nestas Leis tinham por objetivo a melhoria na qualidade do ensino público, partindo do pressuposto que, ao elevar o nível de formação da classe docente, oferecendo uma formação sólida e contínua, o profissional teria melhores condições de desenvolver um bom trabalho em sala de aula. Assim sendo, em consonância com as legislações educacionais vigentes, a rede municipal de ensino de São Paulo passou a exigir o diploma de nível superior para os ingressantes a partir de 2010, o que justifica o número mais elevado de profissionais detentores do diploma de nível superior em Pedagogia.

Também se observou que alguns professores possuíam mais de uma formação inicial. Do universo pesquisado, 12 dos respondentes possuíam Magistério e Pedagogia, o que 
possivelmente indica que estes docentes ingressaram na rede com a primeira formação, de nível médio e, posteriormente, cursaram a formação em nível superior.

A importância da formação docente é ressaltada por Perrenoud (1999), que afirma que a formação inicial do professor não costuma contemplar o domínio da diferenciação pedagógica a ponto de ela ser bem praticada. Supõe-se, portanto, que se nas formações em nível superior já não há embasamento teórico para formar um professor plenamente apto para diferenciar o ensino na sala de aula, haverá menos ainda em cursos que estão abaixo deste nível de ensino.

A formação adicional dos professores pode ser observada na tabela 4, e mostra que $72 \%$ deles realizaram curso de pós-graduação latu sensu, ou seja, possuem alguma especialização na área. Outros 53\% realizaram cursos de extensão; 36\% participaram de aperfeiçoamentos profissionais; e 7,8\% afirmava ter frequentado outros tipos de formação, não necessariamente na área educacional, como cursos técnicos, por exemplo. Com relação aos cursos de pósgraduação strictu sensu, apenas dois professores possuíam mestrado.

A formação docente relaciona-se com o preparo para o trabalho diferenciado na medida em que, quanto mais o professor estuda, se atualiza, se questiona a respeito de suas práticas, melhor preparado ele estará para lidar com os desafios presentes dentro das salas de aula, beneficiando, desta forma, a aprendizagem do aluno.

Tabela 4 - Formação complementar dos respondentes

\begin{tabular}{lcc}
\hline Formação complementar & $\mathbf{N}$ & $\mathbf{\%}$ \\
\hline \multicolumn{1}{c}{ Extensão } & 55 & 53,9 \\
Aperfeiçoamento & 37 & 36,3 \\
Especialização & 74 & 72,5 \\
Mestrado & 2 & 2,0 \\
Outro & 8 & 7,8 \\
\hline
\end{tabular}

Fonte: Base de dados da pesquisa. Organização da autora

No que tange à experiência, como docentes, destes profissionais, o gráfico de tempo de atuação no magistério mostrou que dos 102 professores, aproximadamente $40 \%$ possuía experiência de 16 anos ou mais no magistério; outros $40 \%$ atuavam de 6 a 15 anos; e a menor parcela de respondentes - ao todo 22 - possuía menos de 3 anos ou de 3 a 5 anos de tempo de atuação docente. 
Tabela 5 - Tempo de magistério dos respondentes

\begin{tabular}{lcc}
\hline \multicolumn{1}{c}{$\begin{array}{c}\text { Tempo de experiência } \\
\text { profissional }\end{array}$} & $\mathbf{N}$ & $\mathbf{\%}$ \\
\hline Menos de 3 anos & 10 & 9,8 \\
De 3 a 5 anos & 12 & 11,8 \\
De 6 a 10 anos & 20 & 19,6 \\
De 11 a 15 anos & 20 & 19,6 \\
16 anos ou mais & 40 & 39,2 \\
Total & $\mathbf{1 0 2}$ & $\mathbf{1 0 0 , 0}$ \\
\hline \multicolumn{2}{c}{ Fonte: Base de dados da pesquisa. Organização da autora }
\end{tabular}

Têm-se, por hipótese, que a diferenciação pedagógica e o tempo de experiência no magistério não necessariamente estão relacionados. Pode-se partir da suposição de que um professor com mais experiência de magistério teria mais facilidade em desenvolver um trabalho diferenciado, visto que os anos de atuação, teoricamente, teriam lhe fornecido os subsídios necessários para isso. Porém, esse mesmo docente poderia estar extremamente atrelado a práticas de ensino tidas como tradicionais, não aceitando a inclusão de mudanças ou de outras formas de trabalho pedagógico que seguissem as premissas da diferenciação pedagógica.

Em contrapartida, é possível que um professor recém-formado adentre a escola cheio de ideias novas, com o intuito de fugir dos métodos convencionais e aplicar conhecimentos e práticas que beneficiem o aluno em seu aprendizado, como é caso do trabalho pedagógico diferenciado, ou que, justamente por ser novo no exercício da docência, se sinta inseguro de desenvolver uma prática de desta alçada com seus alunos.

Essas hipóteses se confirmaram na escola onde foi feita a pesquisa de campo, visto que, ao mesmo tempo em que foi possível encontrar professores jovens, dispostos a realizar um atendimento diferenciado, também havia professores com mais tempo de magistério, que se mostravam dispostos a realizar ações deste teor. Em contrapartida, foram encontrados professores extremamente experientes em termos de tempo de serviço, mas que não abriam mão de um ensino mais conservador, e professores mais jovens que também não realizavam um atendimento diferenciado aos seus alunos.

Os dados referentes ao tempo de atuação no ano em que o docente lecionava, quando respondeu ao questionário, mostram que a maior parte dos professores possuía pouco tempo de experiência, o que não necessariamente condiz com o tempo de experiência no magistério. Dos 102 respondentes, $52 \%$ detinha menos de 3 anos de atuação; $21 \%$ atuavam de 3 a 5 anos no 
mesmo ano; $17 \%$ de 6 a 10 anos; $2 \%$ possuíam experiência de 11 a 15 anos; e $6 \%$ atuavam há mais de 16 anos no ano indicado no questionário.

Tabela 6 - Tempo de experiência dos respondentes no ano em que lecionam

\begin{tabular}{lcc}
\hline Tempo de experiência & $\mathbf{N}$ & $\mathbf{\%}$ \\
\hline Nenhuma experiência & 1 & 1,0 \\
Menos de 3 anos & 52 & 51,0 \\
De 3 a 5 anos & 22 & 21,6 \\
De 6 a 10 anos & 18 & 17,6 \\
De 11 a 15 anos & 2 & 2,0 \\
Mais de 16 anos & 7 & 6,9 \\
Total & $\mathbf{1 0 2}$ & $\mathbf{1 0 0 , 0}$ \\
\hline
\end{tabular}

Fonte: Base de dados da pesquisa. Organização da autora.

Confrontando os dados de experiência no magistério com o número de práticas realizadas, descobriu-se que os docentes que assinalaram desenvolver mais práticas de diferenciação pedagógica são os que possuem mais tempo de experiência no magistério: dos 102 respondentes da pesquisa, 41 afirmam realizar mais de 6 tipos de diferenciação pedagógica em suas práticas. Destes, aproximadamente $40 \%$ são professores com mais de 16 anos de experiência no magistério.

Em relação às questões sobre a diferenciação pedagógica propriamente dita, os professores foram indagados se já tinham ouvido falar dos conceitos utilizados para fazer referência a estas práticas, conforme consta na questão 9 do questionário que se encontra no Apêndice 1. A tabela 7 mostra quais foram os resultados obtidos nesta questão.

Tabela 7 - Conceitos relativos à diferenciação pedagógica conhecidos pelos respondentes

\begin{tabular}{|c|c|c|}
\hline Conceitos & $\mathbf{N}$ & $\%$ \\
\hline Instrução diferenciada & 36 & 35,3 \\
\hline Diferenciação pedagógica & 43 & 42,2 \\
\hline Pedagogia diferenciada & 48 & 47,1 \\
\hline Práticas diferenciadas de ensino & 90 & 88,2 \\
\hline
\end{tabular}

Os dados mostram que a expressão práticas diferenciadas de ensino é a mais conhecida pelos docentes, com 90 referências. Isso talvez ocorra pelo fato deste termo ser razoavelmente utilizado em cursos de formação, em alfabetização, oferecidos pela rede municipal, especialmente o PNAIC, que costuma discutir formas diferentes de ensino a fim de facilitar a alfabetização. Já o menos conhecido pelos respondentes é instrução diferenciada, citado por 36 
docentes. Vale lembrar, nesta questão especificamente, que cada respondente poderia assinalar mais de uma alternativa.

Solicitou-se ainda aos respondentes que explicassem seu entendimento sobre o(s) conceito(s) de diferenciação pedagógica assinalado(s), no caso de terem respondido afirmativamente em relação ao conhecimento de um ou mais dos conceitos elencados. Dos 102 respondentes, $83(91 \%)$ forneceram respostas válidas, visto que nos outros 19 questionários essa questão foi deixada em branco.

Por se tratar de uma questão aberta, para facilitar a análise das respostas dadas pelos docentes, foram criadas categorias conceituais, nas quais as informações obtidas pudessem se enquadrar, conforme o seu conteúdo, à análise bibliográfica presente no Capítulo I deste trabalho. Essas categorias têm origem nas contribuições trazidas pelos autores acerca da diferenciação pedagógica, e permitem saber o quanto o entendimento dos docentes está relacionado com o arcabouço teórico da pesquisa.

As demais categorias foram criadas para sistematizar algumas definições, dadas pelos docentes, sobre o conceito de diferenciação pedagógica, mas que não se encaixavam nas categorias criadas com base nas contribuições teóricas, denotando que tais definições não estão de acordo com os conceitos de diferenciação pedagógica.

A primeira categoria, definida como ideia de abordagem didática comprometida com propiciar o aprendizado, tem fundamento na teoria de Perrenoud (2000), que defende que a diferenciação pedagógica deve constituir as práticas em sala de aula a fim de garantir aprendizagens significativas para todos, contribuindo, dessa forma, com o sucesso escolar dos alunos.

A segunda categoria, que diz respeito à ideia de fazer adaptações às necessidades dos educandos, acolhe depoimentos que se baseiam no reconhecimento das diferenças existentes entre os alunos, defendido por Hall, Strangman e Meyer (2002).

A categoria trabalho pedagógico focado na individualidade do aluno também se fundamenta na teoria de Hall, Strangman and Mayer (2002), que afirmam que diferenciar o ensino significa admitir as diversas linguagens, preferências de aprendizagem, interesses e conhecimentos variados e, por conta disso, as abordagens de ensino devem ser variadas e se adaptar em relação à individualidade do aluno.

A categoria estratégia de trabalho com turmas heterogêneas tem fundamentos na teoria de Perrenoud (2000), que discute intensamente a questão das diferenças na sala de aula, defendendo, portanto, a adoção de diferentes estratégias de ensino, que sejam capazes de atender as necessidades de todos. 
A categoria ideia de adaptação curricular se baseia nos escritos de Roldão (1999), que afirma que a diferenciação do currículo deve ser feita não de modo a diminuir ou simplificar o currículo ao qual o aluno terá acesso, mas pela definição de percursos de aprendizagem diferenciados, que possibilitem o progresso de cada aluno no currículo comum.

A categoria uso de estratégias de ensino diversificadas aparece expressivamente nas falas dos docentes e também pode ser encontrada nos escritos de Hall, Strangman and Meyer (2002). Segundo as autoras, diferenciar significa utilizar estratégias de ensino e fazer intervenções diversas, dentro da sala de aula, considerando os diferentes perfis de alunos, incluindo nessas ações, por exemplo, a aplicação de atividades com graus de dificuldades distintos e a utilização de materiais diversos.

A categoria atendimento a alunos com necessidades especiais ou com necessidades específicas de aprendizagem foi criada por aparecer nas falas de diversos docentes. Todavia, relacionar a diferenciação pedagógica ao atendimento a educandos com necessidades especiais é uma ideia equivocada, como já discutido no Capítulo I. Embora o atendimento diferenciado possa beneficiar um aluno com necessidades especiais, ele não é exclusivo para esse fim, tendo como objetivo o atendimento às necessidades de aprendizagem de todos.

A categoria outros abrange definições mais dispersas do conceito de diferenciação, dadas pelos professores, a saber: relação com práticas de ensino; relação com ensino lúdico; ideia de inovação; e relação com construtivismo ou sócio construtivismo.

A explicação da relação com práticas de ensino parece evidenciar uma a falta de clareza por parte destes docentes a respeito do que entendem por diferenciação pedagógica, visto que a resposta fornecida não explica qual é o tipo de relação com tais práticas que o docente atribui à diferenciação.

A relação com ensino lúdico aparece pelo fato de alguns docentes relacionarem os conceitos elencados com a ideia de ludicidade. No entanto, segundo os autores consultados para o levantamento bibliográfico da pesquisa, não foi encontrada nenhuma referência da diferenciação pedagógica com o ensino lúdico.

A ideia de inovação pedagógica também foi citada por alguns professores, porém, também não foram encontradas referências que relacionem diferenciação pedagógica à inovação educacional na literatura que embasa a pesquisa.

Por fim, as respostas, que classificam a diferenciação pedagógica como sócio construtivismo ou construtivismo, trazem consigo uma confusão conceitual. Embora a diferenciação pedagógica tenha suas raízes em alguns autores construtivistas, conforme 
apresentado no Capítulo I, o conceito em si não é de uma prática construtivista, envolvendo uma série de outras formas de agir em sala de aula que vão além das teorias supracitadas.

Tabela 8 - Classificação das explicações dadas pelos respondentes sobre o conceito de diferenciação pedagógica

\begin{tabular}{lcc}
\hline Categorias & $\mathbf{N}$ & $\mathbf{\%}$ \\
\hline $\begin{array}{l}\text { Ideia de abordagem didática comprometida em propiciar o } \\
\text { aprendizado }\end{array}$ & 10 & 9 \\
\hline Ideia de fazer adaptações às necessidades dos alunos & 1 & 0,9 \\
\hline Ideia de trabalho pedagógico focado na individualidade do aluno & 13 & 12 \\
\hline Ideia de estratégia de trabalho com turmas heterogêneas & 18 & 17 \\
\hline Ideia de adaptação curricular & 6 & 5,8 \\
\hline Ideia de uso de estratégias de ensino diversificadas & 12 & 11 \\
\hline $\begin{array}{l}\text { Ideia de atendimento a alunos com necessidades especiais ou } \\
\text { com necessidades específicas de aprendizagem }\end{array}$ & 17 & 16 \\
\hline Outros & 4 & 3,9 \\
\hline Definição não elucidativa & 2 & 1,9 \\
\hline Respostas em branco & 19 & 18 \\
\hline Total & $\mathbf{1 0 2}$ & $\mathbf{1 0 0}$ \\
\hline
\end{tabular}

Fonte: Base de dados da pesquisa. Organização da autora

A tabela 8 mostra que a maior parte dos docentes que responderam a esta questão entende que o conceito de diferenciação pedagógica está relacionado com o desenvolvimento de estratégias de trabalho em turmas heterogêneas.

Verificou-se, porém, que a segunda definição de diferenciação pedagógica mais citada pelos docentes está relacionada com o atendimento de alunos com necessidades especiais ou com necessidades específicas de aprendizagem, não atrelando a ideia de se diferenciar o ensino a uma prática capaz de beneficiar a todos os alunos.

As questões relacionadas às possíveis práticas de diferenciação desenvolvidas pelos docentes, bem como a frequência de realização das mesmas, trouxeram elementos bastante enriquecedores para a discussão da temática em estudo, os quais serão explorados posteriormente.

Começando pelos tipos de diferenciação, a tabela 9 reporta os dados da quantidade de ações que os professores afirmaram realizar, bem como a frequência do desenvolvimento destas práticas. Inicialmente cabe destacar que são pouquíssimos os professores, que afirmam não 
desenvolver nenhuma forma de diferenciação com seus alunos em relação ao universo pesquisado.

Tabela 9 - Frequência absoluta e relativa dos tipos de diferenciação pedagógica realizados pelos respondentes

\begin{tabular}{|c|c|c|c|c|c|c|}
\hline \multirow{3}{*}{ Tipo de diferenciação } & \multicolumn{6}{|c|}{ Frequência de realização da diferenciação } \\
\hline & \multicolumn{2}{|c|}{ Nunca } & \multicolumn{2}{|c|}{ Ocasionalmente } & \multicolumn{2}{|c|}{ Frequentemente } \\
\hline & $\mathrm{N}$ & $\%$ & $\mathrm{~N}$ & $\%$ & $\mathrm{~N}$ & $\%$ \\
\hline Diferenciação de conteúdos & 44 & 43,1 & 31 & 30,4 & 27 & 26,5 \\
\hline $\begin{array}{l}\text { Diferenciação de } \\
\text { expectativas de } \\
\text { aprendizagem }\end{array}$ & 26 & 25,5 & 24 & 23,5 & 52 & 51,0 \\
\hline Diferenciação de materiais & 8 & 7,8 & 32 & 31,4 & 62 & 60,8 \\
\hline $\begin{array}{l}\text { Diferenciação de práticas } \\
\text { de ensino }\end{array}$ & 15 & 14,7 & 17 & 16,7 & 70 & 68,6 \\
\hline Diferenciação de atividades & 5 & 4,9 & 21 & 20,6 & 76 & 74,5 \\
\hline $\begin{array}{l}\text { Diferenciação de } \\
\text { intervenção pedagógica }\end{array}$ & 10 & 9,8 & 11 & 10,8 & 81 & 79,4 \\
\hline
\end{tabular}

Fonte: Base de dados da pesquisa. Organização da autora.

Partindo para os tipos de diferenciação estabelecidos conforme as categorias de análise, a diferenciação da intervenção pedagógica é a prática mais presente no discurso dos professores que responderam ao questionário, visto que 79,4\% afirmam desenvolver esse tipo de diferenciação.

Já a diferenciação de conteúdos/currículo é a prática de diferenciação menos realizada, segundo os depoimentos, sendo feita com maior frequência por apenas $27 \%$ do total de respondentes. Em comparação a outras formas de diferenciação, o número de professores que afirmam não realizar esse tipo de pratica é bem expressivo.

A diferenciação das práticas de ensino também aparece como uma das ações mais citadas pelos professores, sendo feita com frequência por aproximadamente $70 \%$ do total dos respondentes, e ocasionalmente por cerca de $17 \%$ deles. Esse tipo de diferenciação diz respeito às diversas formas as quais o professor pode utilizar para explicar um determinado conteúdo, a fim de que todos possam entendê-lo.

A diferenciação de intervenção pedagógica diz respeito às diversas formas que o docente tem de agir com cada aluno em prol do avanço de sua aprendizagem, por exemplo, dispensandose mais tempo aos alunos com dificuldades. Cerca de $80 \%$ dos respondentes afirmam realizar esse tipo de prática com frequência.

De acordo com os dados apresentados pela Tabela 9, percebe-se que, de todos os tipos de diferenciação elencados, a diferenciação de atividades aparece como a prática que os 
docentes mais afirmam realizar em suas classes, se forem somados os que as fazem com frequência e ocasionalmente. Observa-se que muitos docentes confundem a diferenciação de atividades com uma forma considerada não tradicional de se explicar um conceito. Uma das respondentes afirma, por exemplo, que "realiza a confecção de brinquedos e atividades de matemática para seus alunos com embalagens”, porém, neste caso, ela dá a entender que é uma atividade aplicada a todos, mudando apenas a forma que usou para trabalhar um determinado conteúdo.

A partir do arcabouço teórico que fundamenta este trabalho, depreende-se que a proposta de diferenciação de atividades, na concepção da diferenciação pedagógica, seria, por exemplo, o preparo e aplicação de atividades com comandas diferentes, de forma a atender os diversos níveis de aprendizagem presentes, ao mesmo tempo, em uma sala de aula.

A diferenciação de materiais também é uma prática de diferenciação pedagógica citada por grande parte dos respondentes, sendo que, cerca de $60 \%$ dos respondentes afirmam realizála frequentemente. A queda nesse tipo de prática, em relação às formas de diferenciação de intervenção pedagógica, de ensino e de atividades causa estranhamento, visto que as escolas municipais costumam disponibilizar diversos tipos de recurso aos docentes. É provável que, a menor utilização desse tipo de diferenciação possa estar relacionada ao maior tempo necessário para o planejamento de atividades diferenciadas, com base nos materiais disponíveis.

A diferenciação de expectativas de aprendizagem é, juntamente com a diferenciação de conteúdos, uma das práticas que os docentes menos realizam. Tem-se a hipótese de que os docentes optam por não realizar essa prática por acreditarem que, se exigirem menos de alguns alunos, estarão diminuindo as expectativas de aprendizagem deles, fomentando, assim, a desigualdade entre alunos de uma mesma classe, ao invés de auxiliar os que possuem mais dificuldade.

De fato, é necessário ter cuidado com esse tipo de diferenciação para que, justamente, não se incorra no erro de inferiorizar o aluno, desconsiderando suas possibilidades de aprendizagem e, por isso, exigindo-lhe menos.

É aceitável esperar produtos diferentes de alunos que estão em níveis diferentes de aprendizagem, por exemplo: de um aluno alfabético, espera-se a leitura de listas, frases, textos; de um silábico alfabético, espera-se a identificação de sílabas nas palavras, e assim em diante; é esse o tipo de diferenciação de expectativas ideal. O que não deve acontecer é a diminuição das expectativas de aprendizagem pelo fato de o professor pensar que o aluno não é capaz, e, por acreditar que não adianta insistir, exigir-lhe menos do que exige dos alunos que considera bons. 
Quando se pede aos respondentes que apenas assinalem as práticas de diferenciação que desenvolvem, como é o caso dos dados apresentados na tabela 9, o resultado obtido é alto: considerando-se a média das três Diretorias Regionais de Ensino, esse número fica em torno de 76\% dos que afirmam realizar entre 4 e 6 tipos de diferenciação.

Todavia, quando se solicita aos respondentes que descrevam como ocorrem as práticas que eles assinalaram, esse número cai drasticamente: apenas 36 dos pesquisados - o que equivale a $35 \%$ do total - descreveram práticas em conformidade com as ações de diferenciação. O que ocorre é que boa parte das definições dadas pelos docentes que afirmaram realizar determinados tipos de prática, não se enquadram no que realmente é preconizado pela teoria referente à diferenciação, fazendo com que o número de práticas realizadas, de fato, caia drasticamente.

Outra questão que influenciou para que número de práticas realizadas diminuísse, foi o fato de que, em boa parte das respostas, o docente assinala várias práticas, mas fornece a descrição de apenas parte delas, impossibilitando a análise das demais práticas que elencadas.

Comparando a quantidade de tipos de diferenciação praticados em cada Diretoria, têmse que, nas três DREs observadas, o número de docentes que afirmam não realizar nenhuma das práticas elencadas é pequeno em relação ao todo, totalizando aproximadamente $10 \%$ dos respondentes.

Também se observou que, em todas as DREs, a porcentagem de docentes que afirmam praticar, no mínimo, quatro formas de diferenciação pedagógica, é expressiva: em média, 76\% dos professores aplicam entre quatro e seis formas de diferenciação em suas práticas pedagógicas, sendo que Itaquera é a Diretoria que detém o maior número de práticas realizadas pelos docentes, com $81 \%$ do total. (Tabela 10)

Tabela 10 - Frequência absoluta e relativa de tipos de diferenciação praticados em cada diretoria

\begin{tabular}{lcccccccc}
\hline & \multicolumn{2}{c}{$\begin{array}{c}\text { Não } \\
\text { diferenciam }\end{array}$} & \multicolumn{2}{c}{$\begin{array}{c}\text { Afirmam } \\
\text { realizar de 1 a } \\
\text { 3 tipos de } \\
\text { diferenciação }\end{array}$} & \multicolumn{2}{c}{$\begin{array}{c}\text { Afirmam } \\
\text { realizar de 4 a } \\
\text { 6 tipos de }\end{array}$} & \multicolumn{2}{c}{$\begin{array}{c}\text { Total de } \\
\text { respondentes } \\
\text { por diretoria }\end{array}$} \\
\cline { 2 - 10 } & $\mathbf{N}$ & $\mathbf{\%}$ & $\mathbf{N}$ & $\mathbf{\%}$ & $\mathbf{N}$ & $\mathbf{\%}$ & $\mathbf{N}$ & $\mathbf{\%}$ \\
\hline Butantã & 1 & 0,9 & 5 & 4,9 & 11 & 10 & 17 & 17,3 \\
\hline Ipiranga & 0 & 0 & 11 & 10 & 37 & 36 & 48 & 48,9 \\
\hline Itaquera & 3 & 2,9 & 4 & 3,9 & 30 & 29 & 37 & 37,7 \\
\hline Total & $\mathbf{4}$ & $\mathbf{3 , 9}$ & $\mathbf{2 0}$ & $\mathbf{1 9}$ & $\mathbf{7 8}$ & $\mathbf{7 6}$ & $\mathbf{1 0 2}$ & $\mathbf{1 0 0}$ \\
\hline
\end{tabular}

Fonte: Base de dados de pesquisa. Organização da autora. 
Após assinalarem quais formas de diferenciação eram feitas - e se eram feitas, solicitouse aos docentes que descrevessem como essas ações eram desenvolvidas com os alunos, a fim de se estabelecer ou não uma relação fidedigna com as práticas de diferenciação pedagógica apresentadas pela literatura referente ao assunto.

Nesse caso, considerou-se como respostas válidas apenas as que forneceram informações que contribuíssem para o entendimento das questões pesquisadas. As perguntas deixadas em branco ou com respostas não elucidativas ${ }^{9}$ foram contabilizadas no mesmo indicador.

Com relação à análise das respostas válidas, foi possível fazer três interpretações distintas para a mesma questão. Colocada a descrição das práticas, considerou-se, primeiro, se a ação relatada pelo docente era condizente com as práticas de diferenciação pedagógica; depois, caso a prática fosse condizente, que tipo de diferenciação estava sendo relatada; e, por último, uma observação sobre os docentes que descreviam uma prática pertinente, mas tinham como foco os alunos com necessidades educativas especiais.

A tabela 11 apresenta as seguintes informações: do número total de respostas, quantas podem ser consideradas ações condizentes com as práticas de diferenciação pedagógica; quantas ações foram consideradas válidas parcialmente; quantas respostas não continham informações suficientes para classificar a prática descrita como ação de diferenciação; e quantas respostas não podem ser consideradas ações diferenciação pedagógica.

Tabela 11 - Categorização da adequação das práticas descritas pelos docentes com base na teorização

\begin{tabular}{lcc}
\hline Descrição das práticas docentes & N & \% \\
\hline Prática de acordo & 36 & 35 \\
\hline Prática não condizente & 30 & 29 \\
\hline Não explica o suficiente & 21 & 20 \\
\hline De acordo parcialmente & 6 & 5,8 \\
\hline Não praticam ou respostas em branco & 9 & 8,8 \\
\hline Total & $\mathbf{1 0 2}$ & $\mathbf{1 0 0}$ \\
\hline
\end{tabular}

Fonte: Base de dados da pesquisa. Organização da autora

Foram consideradas respostas adequadas as que descrevem aspectos indicados nas categorias de análise definidas no Capítulo III com base na bibliografia utilizada na pesquisa

\footnotetext{
${ }^{9}$ Como resposta não elucidativa entende-se: informações que, por si só, não permitiam a compreensão do que, de fato, era realizado em sala de aula, impossibilitando que se estabelecesse a relação com o conceito de diferenciação pedagógica.
} 
. Cabe esclarecer que, primeiramente, considerou-se se a resposta fornecia elementos suficientes para que se pudesse analisar seu teor. Quando isso não ocorria, a resposta foi categorizada como "não explica o suficiente". Se as ações estavam de acordo com os aportes trazidos pela literatura sobre diferenciação, a resposta foi classificada como "de acordo". As ações foram consideradas parcialmente de acordo, quando a resposta dada trazia elementos condizentes com uma prática diferenciada, ao mesmo tempo em que apontava práticas que não estavam de acordo com tais ações. Respostas ausentes ou respostas negativas à questão foram classificadas como "Não praticam ou respostas em branco".

A tabela 12 sintetiza os dados da Tabela 11 em duas categorias: a adequação ou não das práticas descritas pelos docentes ao referencial teórico utilizado, reiterando que em geral os depoimentos não refletem práticas que podem ser consideradas como ações de diferenciação.

Tabela 12 - Frequência absoluta e relativa de práticas de diferenciação pedagógica condizentes - ou não - com os princípios teóricos

\begin{tabular}{lll}
\hline & $\mathbf{N}$ & $\mathbf{\%}$ \\
\hline $\begin{array}{l}\text { Práticas condizentes com a } \\
\text { teorização }\end{array}$ & 36 & 37,3 \\
\hline $\begin{array}{l}\text { Práticas que não refletem os } \\
\text { princípios teóricos da diferenciação }\end{array}$ & 66 & 67,3 \\
\hline
\end{tabular}

Fonte: Base de dados da pesquisa. Elaboração da autora.

\footnotetext{
${ }^{10}$ Relembrando, estes foram os indicadores de práticas definidos no Capítulo III: se o professor reúne pequenos grupos para reforçar uma ideia ou habilidade, no caso de alunos que apresentam dificuldades, ou para ampliar o pensamento ou as habilidades dos alunos que se encontram em níveis avançados; o professor ministra conteúdos diferentes para um aluno ou outro; a sequência do ensino de certos conteúdos é diferente para alguns alunos; a atenção dispensada pelo professor aos alunos é diferente com relação a cada necessidade, sem que, no entanto, isso se configure como uma ação de discriminação negativa dentro da sala de aula; a forma de explicação de um determinado assunto muda se um aluno não entendeu o que foi dito pelo professor; o professor dispensa mais tempo com alguns alunos do que com outros, conforme as necessidades apresentadas; o professor desenvolve formas diferentes de auxiliar os alunos quando estes encontram dificuldade em suas aprendizagens; se uma tática não deu certo, o professor busca novas estratégias de auxiliar o aluno na aquisição do conhecimento; a aplicação de atividades referentes a um mesmo conteúdo, mas com graus de dificuldade diferentes conforme o nível dos alunos; a aplicação de atividades com comandas diferentes de acordo com o aluno; se o professor sintetiza, muda, acrescenta atividades para alguns, e para outros, não; se o professor trabalha com listas de materiais de leitura de diferentes níveis; se são utilizadas listas de ortografia ou vocabulário de acordo com os níveis dos alunos; são utilizados diferentes tipos de materiais e/ou recursos pedagógicos (jogos, material dourado, letras móveis, dentre outros) na explicação dos conteúdos, para que haja maior entendimento do que está sendo ensinado e todos os alunos possam atingir os objetivos propostos. O manuseio de materiais pedagógicos diversos pelos alunos, durante a realização de atividades, com o intuito de promover experiências que possam satisfazer a todos; se o professor diferencia o que espera que os alunos aprendam, conforme suas possibilidades sem, no entanto, limitar o desenvolvimento dos mesmos; há um plano na escola para diferenciar expectativas de aprendizagem para atender alunos com necessidades educativas especiais; o professor possibilita aos estudantes opções diferenciadas sobre como expressar sua aprendizagem; o professor incentiva os alunos a elaborarem suas próprias criações, ou seja, seu próprio produto de aprendizagem; o professor permite que os alunos trabalhem sozinhos ou em pequenos grupos em seus produtos de aprendizagem.
} 
A análise das respostas que indicam práticas de diferenciação pedagógica coerentes com os indicativos teóricos, permite observar que, em geral, os professores realizam diferenciação de atividades e materiais, como pode ser observado na Tabela 13. As demais práticas aparecem quase que na mesma proporção, sendo que a menos mencionada foi a diferenciação de conteúdos/currículos.

Tabela 13 - Categorização de práticas descritas pelos respondentes, de acordo com os tipos de diferenciação

\begin{tabular}{lcc}
\hline Tipo de diferenciação realizada & $\mathrm{N}$ & $\%$ \\
\hline Conteúdo/currículo & 2 & 5,5 \\
\hline Práticas/estratégias & 3 & 8,3 \\
\hline Intervenção & 6 & 16,5 \\
\hline Atividades & 26 & 72 \\
\hline Materiais & 19 & 52 \\
\hline Expectativas & 3 & 8,3 \\
\hline Fonte: Base de dados da pesquisa. Organização da autora
\end{tabular}

* Vale observar que o total de respostas é maior que o número de respondentes ( $\mathrm{n} \geq 36$ ), tendo em vista que foi possível identificar mais de uma prática de diferenciação na mesma fala de vários respondentes.

Dos 36 professores que descreveram práticas coerentes, 15 (41,5\%) desenvolviam ações de diferenciação voltadas apenas aos alunos com dificuldades de aprendizagem ou necessidades educativas especiais, sem transferir esse tipo de prática para toda a classe. Isso mostra o entendimento equivocado que muitos docentes têm de que a diferenciação é necessária para atender apenas os alunos que não acompanham o ritmo "normal" da sala de aula.

Todavia, um dos respondentes demonstra ter clareza de que a diferenciação pedagógica é uma ação que deve beneficiar a toda sala. $\mathrm{O}$ relato a seguir descreve a prática realizada:

Atividades diferenciada para os que tem dificuldade possa avançar. Além disso a intervenção é mais direta para aqueles que tem mais dificuldade. Atividades com nível de dificuldade maior para os que estão mais avançados no processo de aprendizagem. (Prof. Ita1_3) ${ }^{11}$.

O docente especifica as ações desenvolvidas, mostrando que há um atendimento diferenciado dependendo do nível em que se encontra o aluno, considerando que as salas de aula são compostas de forma heterogênea, o que permite contemplar alunos com mais dificuldade e alunos mais avançados no processo de aprendizagem. Se as atividades aplicadas

${ }^{11}$ Os depoimentos dos professores foram transcritos sem alterações, mantendo-se, fielmente, os relatos dos entrevistados. 
são as mesmas para todos, o que possui dificuldade não consegue acompanhar a classe, e o aluno que se encontra algum nível acima dos demais, se sente desmotivado.

Para ilustrar as ações que vem sendo desenvolvidas pelos docentes, são descritos, a seguir, alguns exemplos de cada prática de diferenciação pedagógica considerada pertinente nesta pesquisa.

Como já mencionado anteriormente, a prática que mais aparece na análise dos relatos docentes é a diferenciação de atividades, descrita em $72 \%$ dos questionários que forneceram respostas válidas para essa questão. O depoimento a seguir apresenta um exemplo sobre como diferenciar as atividades em prol do aprendizado das crianças:

Trabalho em uma comunidade carente, enquanto alguns alunos já sabem ler e outros não reconhecem nem a vogal. Faço adaptações em algumas atividades, e neste caso a abordagem é totalmente diferente, enquanto com um grupo posso trabalhar reescrita, pontuação, estrutura de texto, por exemplo, outro trabalho alfabeto, ensinando leitura e escrita de coisas menos complexas. (Prof. But3_1)

A aplicação de atividades diferentes, conforme o nível em que a criança se encontra, permite que todos os alunos avancem em suas aprendizagens, visto que cada aluno estará diante de situações coerentes com o que ele é capaz de realizar naquele momento, não ficando desmotivado ou perdido em relação ao que lhe é exigido. Outro depoimento ilustra a especificidade da diferenciação de atividades aplicadas aos alunos:

A partir das expectativas de aprendizagem definimos objetivos a serem alcançados no ano letivo, cada criança "funciona" de um jeito, os conteúdos são os mesmos para todos, contudo, as "atividades" são adequadas ao nível em que a criança se encontra em alfabetização (S.S.V, pré-silábico, S.C.V.S, S.A e alfabético). O mesmo ocorre com matemática. Chego a elaborar 6 tipos de "atividades" para contemplar o desenvolvimento das crianças após realizarmos problematizações que são comuns a todos. (Prof. But1_5)

Observa-se que a aplicação de uma mesma atividade, com o mesmo conteúdo, mas com comandas diferentes, denota a preocupação em atender as diferentes necessidades educativas presentes em uma sala de aula, sem minimizar conteúdos para grupos que se encontram ainda em níveis de aprendizado inferiores ao do restante da classe.

A segunda prática mais desenvolvida pelos docentes, segundo seus depoimentos, é a diferenciação de materiais, que aparece em 52\% dos depoimentos. O depoimento a seguir exemplifica uma ação de diferenciação de materiais.

Em alfabetização temos leitura diária e problematizações onde todo o coletivo participa; para o trabalho individual com cada criança elaboro exercícios, próprios à hipótese onde esta se encontra. Também utilizo jogos e brincadeiras 
em grupo reunindo crianças que se encontram em níveis próximos, sendo que as trocas entre elas representam verdadeiros "picos" de aprendizagem devido às trocas realizadas. (Prof ${ }^{a}$ But1_5)

Embora tenha características de uma ação de diferenciação de atividades, a prática relatada no depoimento também pode ser considerada um exemplo de diferenciação de materiais, pelo fato de o docente disponibilizar recursos diversos, como jogos e brincadeiras para auxiliar o aprendizado de seus alunos. É importante lembrar que as categorias foram escolhidas com propósitos didáticos, sendo necessário fazer conexões entre as formas de diferenciação pedagógica exploradas nesta pesquisa.

A diferenciação de intervenção pedagógica pode ser encontrada em $16 \%$ das ações analisadas, e algumas falas dos docentes trazem aspectos relativos a esse tipo de diferenciação, como é o caso do trecho a seguir:

Observando que algum aluno não conseguiu assimilar o conteúdo passado, troco as estratégias, percebendo que mesmo assim alguns não conseguem se apropriar do conteúdo, faço intervenções individuais. (Prof. Ipi3_20)

Entende-se, pelo depoimento, que a intervenção varia conforme a necessidade apresentada, e embora a ação descrita possa ser comum a professores que não desenvolvem nenhum tipo de práticas diferenciadas em suas classes, o que o docente relata em sua fala não está muito distante de constituir uma forma diferenciada de se intervir no ensino, conforme a necessidade apresentada. Porém o professor direciona esse tipo de ação para alunos com dificuldade, o que foge da intencionalidade da diferenciação pedagógica.

A diferenciação de práticas/estratégias e a diferenciação de expectativas de ensino aparecem na mesma proporção. Um dos docentes, que afirma diferenciar as expectativas de aprendizagem, justifica a adoção dessa prática com base na questão das diferenças de ritmos de aprendizagem dos alunos, esperando produtos de acordo com o nível da criança, conforme a fala a seguir:

Com relação aos alunos que possuem um ritmo de aprendizagem diferente dos demais, as minhas expectativas ao avaliá-lo estão dentro deste parâmetro. (Prof ${ }^{a}$. But0_0).

Outro docente cita o trabalho com expectativas de aprendizagem diferenciadas, mas não dá mais detalhes de quais são os critérios utilizados para tal:

Com atividades com graus de dificuldade diferentes, materiais de apoio, intervenções individuais e sobretudo com expectativas diferentes de aprendizagens. (Prof ${ }^{a}$. Ipi1_1) 
Por último, a prática que menos aparece nos discursos é a diferenciação de conteúdos/currículos, tendo sido descrita em apenas 5,5\% das respostas analisadas. A fala a seguir é uma das poucas que ilustram uma tentativa de diferenciação de conteúdos:

Pelo fato de ter alunos no $3^{\circ}$ ano não alfabéticos, elaborei um projeto à parte de alfabetização para tentar fazer um trabalho para acelerar a alfabetização, com conteúdo e estratégia diferenciadas. (Prof. Ita3_3).

O docente cita o desenvolvimento de atividades voltadas a um grupo específico, que já deveria estar alfabetizado pelo ano em que se encontra, o que indica se tratar de alunos com dificuldades escolares. Fica claro que o objetivo desta ação é fazer com que esses alunos sejam alfabetizados, e é nesse sentido que ocorre a diferenciação de conteúdos em relação ao restante da sala.

Para compreender se os respondentes consideravam importante o conceito de diferenciação pedagógica, e em que sentido justificavam essa importância, incorporou-se ao questionário um item aberto. As respostas obtidas foram organizadas em categorias, com o objetivo de sistematizá-las, conforme a justificativa dada pelos docentes para se diferenciar o ensino. Na construção das categorias, foram consideradas algumas referências do referencial teórico. São elas:

a) respeito aos diferentes perfis e formas de aprender do alunado (Hall, Strangman and Mayer, 2002);

b) garantia do aprendizado de todos (Perrenoud, 2000);

c) facilitação do ensino e da aprendizagem (Pacheco, 2008; Hall, Strangman and Mayer, 2002)

d) consideração dos interesses dos alunos (Perrenoud).

Em cada uma das categorias foram criados indicadores aos quais se relacionam as respostas dos professores, que se encontram em uma tabela mais detalhada no APÊNDICE deste trabalho. A tabela 14 aponta os resultados dessa categorização.

Os dados mostram que uma parcela considerável dos docentes compreende a importância de se diferenciar o ensino em sala de aula, refletindo os aportes da teoria que embasa o conceito em questão. A justificativa mais citada para se diferenciar o ensino consiste no respeito aos diferentes perfis e formas de aprender do alunado, destacado por 39 dos 73 respondentes que forneceram respostas válidas, ou seja, aquelas incluídas apenas nas quatro categorias apresentadas. 
Tabela 14 - Justificativas sobre a importância da diferenciação, conforme os respondentes

\begin{tabular}{lcc}
\hline Categoria & N & $\%$ \\
\hline $\begin{array}{l}\text { Respeito aos os diferentes perfis e formas de } \\
\text { aprender do alunado }\end{array}$ & 39 & 38 \\
\hline Garantia do aprendizado de todos & 8 & 7,8 \\
\hline Facilitação do ensino e das aprendizagens & 20 & 19 \\
\hline Consideração dos interesses dos alunos & 6 & 5,8 \\
\hline Respostas não pertinentes & 9 & 8,8 \\
\hline $\begin{array}{l}\text { Respostas incompletas, não elucidativas ou em } \\
\text { branco }\end{array}$ & 19 & 18 \\
\hline Não considera importante diferenciar & 1 & 0,9 \\
\hline
\end{tabular}

Fonte: Base de dados da pesquisa. Organização da autora

Um exemplo de compreensão adequada acerca do conceito, é ilustrado pelo depoimento a seguir:

[...] porque cada indivíduo aprende de uma forma e a diferenciação fará o aluno e o professor a conhecer melhor o aluno e com qual forma o mesmo aprende e se desenvolve com mais facilidade. (Prof. But1_3).

Outro exemplo que também reflete a compreensão dos docentes sobre a importância de se diferenciar o ensino pode ser encontrado no seguinte depoimento:

[...] porque atende a criança em sua especificidade e assim de uma forma diferenciada ela poderá alcançar as demais e desta forma se garante o direito de aprendizagem. (Prof. Ipi2_7).

A fala denota a consideração da especificidade da criança de forma geral, não focando essa característica nos alunos que têm mais dificuldades ou que possuem necessidades específicas.

Por fim, com relação ao conhecimento da terminologia utilizada para se referir à diferenciação pedagógica, os docentes foram questionados se conheciam outras expressões que denotassem esse tipo de ação. Dos 102 participantes, apenas 28 responderem à questão afirmativamente.

A tabela 15 mostra quais foram as expressões citadas. Lembrando que, por se tratar de uma questão aberta, os docentes poderiam elencar mais de uma expressão. 
Tabela 15 - Expressões e termos citados pelos respondentes para se referir ao conceito de diferenciação pedagógica

\begin{tabular}{lcc}
\hline Expressões/termos citados pelos docentes & $\mathrm{N}$ & $\%$ \\
\hline Adaptação curricular e metodológica & 1 & 0,9 \\
\hline Direitos humanos e inclusão & 1 & 0,9 \\
\hline Sócio construtivismo/construtivismo & 4 & 3,9 \\
\hline Flexibilização de currículo & 1 & 0,9 \\
\hline Intervenção pedagógica & 1 & 0,9 \\
\hline Estratégias diferenciadas & 1 & 0,9 \\
\hline Atividades diferenciadas/diversificadas & 5 & 4,5 \\
\hline Turmas heterogêneas & 1 & 0,9 \\
\hline Recuperação contínua & 1 & 0,9 \\
\hline Didática e metodologia diferenciada & 1 & 0,9 \\
\hline Trabalho pedagógico adaptado & 1 & 0,9 \\
\hline Adequação curricular & 1 & 0,9 \\
\hline Adaptação de currículo/adaptação curricular & 2 & 1,9 \\
\hline Práticas diferenciadas de ensino & 3 & 2,7 \\
\hline Pedagogia diferenciada & 2 & 1,9 \\
\hline Práticas lúdicas no ensino e aprendizagem. & 1 & 0,9 \\
\hline Não conhecem outros termos ou fornecem respostas evasivas & 54 & 52 \\
\hline Outros* & 2 & 1,9 \\
\hline Respostas em branco & 20 & 19 \\
\hline Total & $\mathbf{1 0 2}$ & $\mathbf{1 0 0}$ \\
\hline Fonte: Base de dados da pesquisa. Organização da autora & & \\
*Respostas incoerentes & & \\
\hline
\end{tabular}

O termo mais citado pelos docentes como forma de se referir ao conceito de diferenciação pedagógica é o que se relaciona ao conceito de construtivismo ou sócio construtivismo.

Em seguida, têm-se a expressão práticas diferenciadas de ensino, que é uma das formas já apresentadas aos docentes no questionário. Verificou-se que alguns docentes, mesmo tendo afirmado conhecer outras nomenclaturas para o conceito de diferenciação pedagógica que não os apresentados pela pesquisa, ao citarem o referido termo, repetem as expressões já apresentadas no questionário. Isso ocorreu em 5 respostas.

As demais expressões são mencionadas por, no máximo, um ou dois professores cada uma. Como se trata de uma resposta muito particular de cada docente, é de se esperar que o número de vezes que cada termo aparece não seja expressivo.

Dentre os termos elencados, é possível destacar alguns que estão relacionados, de fato, ao conceito de diferenciação pedagógica: flexibilização curricular, adaptação de currículo (ou adaptação curricular) e adequação curricular, citadas, as três juntas, por quatro docentes.

Finalizando a análise deste instrumento, pode-se afirmar que os dados trazidos pelos questionários permitem inferir algumas ações de teor diferenciado nas práticas dos professores, 
segundo as declarações obtidas. As informações, não permitem, no entanto, perceber com maiores detalhes como se dão as ações de diferenciação ou se elas ocorrem, de fato, na realidade cotidiana das escolas. Para compreender melhor a natureza dessas ações no cotidiano escolar, procedeu-se a observações de campo em uma escola, a fim de poder aprofundar a compreensão sobre como os docentes percebem, se apropriam e utilizam tais práticas no seu cotidiano.

\section{III.3 - Observações de campo}

Conforme já dito, a escolha das escolas de campo foi condicionada aos resultados obtidos por meio dos questionários. Por esse motivo as observações de campo foram iniciadas após a tabulação dos dados dos questionários. A análise para a definição destas escolas considerou quatro aspectos centrais:

- Primeiro e principal aspecto: o número de docentes por escola, para que fosse possível deduzir se as práticas de diferenciação eram desenvolvidas pela escola ou se teriam caráter isolado de prática do docente;

- Segundo aspecto: a definição, dada pelos respondentes, sobre o que entendiam por um ou mais dos termos, apresentados para designar as práticas de diferenciação pedagógica;

- Terceiro aspecto: a descrição feita sobre as práticas de diferenciação que afirmavam realizar, procurando observar sempre o quanto estas práticas eram detalhadas e em que medida eram mais coerentes com os pressupostos estudados.

- Quarto aspecto: se os professores afirmavam realizar, pelo menos, 3 ou mais práticas de diferenciação;

Desta forma, depois de concluída a análise do material, definiu-se quais seriam as escolas a serem estudadas com mais profundidade, o que resultou em três unidades, uma de cada DRE participante da pesquisa. Para preservar sua identificação, elas são referidas por meio de códigos: DRE Butantã: EMEF BT 3, DRE Ipiranga: EMEF IP 13 e DRE Itaquera: EMEF IQ 7.

A primeira escola com a qual foi feito contato foi a EMEF IQ 7, da DRE Itaquera. O contato inicial foi feito com a equipe da gestão que, após contatar a Diretoria Regional de Ensino, autorizou a entrada na unidade e agendou uma primeira conversa, na qual foi esclarecida a proposta de pesquisa que, de imediato, foi aceita pelos responsáveis.

Após esse primeiro contato, a proposta foi apresentada aos docentes, aos quais foi explicado que a entrada nas salas só ocorreria com a permissão dos mesmos, caso concordassem 
em participar da pesquisa. Nenhum docente rejeitou a entrada da pesquisadora em suas salas de aula, e o experimento ocorreu sem maiores intercorrências.

Já a entrada nas outras unidades escolares não ocorreu da forma prevista, sendo necessário modificar o plano inicial, que era explorar práticas de diferenciação em diferentes escolas, de diferentes Diretorias Regionais. No caso da DRE Butantã, ainda que a gestão da escola tenha permitido a realização da pesquisa, não houve aquiescência de parte dos professores das salas de alfabetização para a realização das observações e entrevistas. Como o intuito não era observar práticas isoladas de docentes, mas, sim, compreender o lugar da diferenciação no Projeto Pedagógico das escolas, decidiu-se não realizar a pesquisa na escola selecionada. Considerando que o número de respostas ao questionário, nas outras unidades escolares, não foi satisfatório, a pesquisa nesta diretoria ficou inviabilizada.

Em relação à Diretoria Ipiranga, a unidade escolar selecionada, aqui denominada EMEF IP 13, não mostrou abertura para a realização da pesquisa. Ainda que todos os documentos solicitados já tivessem sido enviados à Diretoria de Ensino, sendo a entrada nas escolas autorizada, a escola, em questão, solicitou novamente a documentação e não deu retorno à pesquisadora em relação ao pedido de reunião para apresentação do projeto de pesquisa. Considerando-se essa situação e a necessidade de revisão do cronograma da pesquisa ${ }^{12}$, decidiuse analisar, em caráter ilustrativo, apenas os dados oriundos da observação na escola da Diretoria Itaquera, apresentados na próxima seção.

\section{III.4. Diferenciação pedagógica na EMEF IQ 7: possibilidades e limites}

A unidade IQ 7 está localizada na zona leste de São Paulo, em bairro de classe média baixa, sendo sua clientela composta por alunos pertencentes a este nível socioeconômico.

É considerada uma escola de porte grande, que atende as seguintes etapas de ensino: Ensino Fundamental I e II, nas modalidades Regular e Educação de Jovens e Adultos - EJA. Possui um total de 97 funcionários, dos quais 58 são docentes - destes, 26 são professores de Ensino Fundamental I. O quadro de funcionários de gestão escolar é composto por: diretora, duas assistentes de direção e duas coordenadoras pedagógicas.

Trata-se de uma escola antiga, porém bem organizada e limpa. Possui boa infraestrutura, contando com laboratório de informática, sala de leitura, quadra poliesportiva, parque, brinquedoteca e sala para atendimento de alunos com necessidades especiais.

\footnotetext{
${ }^{12} \mathrm{O}$ cronograma foi revisto tendo em vista a gestação da pesquisadora e sua premente licença maternidade.
} 
Em 2016, ano em que foi realizada a pesquisa, havia 777 alunos matriculados no Ensino Fundamental I ( $1^{\circ}$ ao $5^{\circ}$ ano); 480 no Ensino Fundamental II e 126 na EJA, anos iniciais e finais, totalizando 1383 matrículas.

No Ciclo de Alfabetização havia cinco salas de $1^{\circ}$ ano, que atendiam um total de 152 alunos; cinco salas de $2^{\circ}$ ano, com 194 alunos e cinco salas de $3^{\circ}$ ano, com 137 alunos, perfazendo um total de 483 matriculados nestes anos (Fonte: QEdu, 2016).

No que diz respeito aos níveis de proficiência dos $5^{\circ}$ anos em Leitura e interpretação, na Prova Brasil em 2015, têm-se que, dos 121 alunos que participaram do teste (de um total de 138), $30 \%$ estavam em nível avançado, $33 \%$ em nível proficiente; $26 \%$ no nível básico e $11 \%$ apresentavam nível insuficiente. (Fonte: QEdu, 2016).

Os dados que compõem esta seção foram construídos com base nas observações, que ocorreram em um total de 12 salas de aula pertencentes ao Ciclo de Alfabetização e tiveram como referência as categorias de análise da pesquisa, e nas entrevistas com professores e gestores.

Para a realização das entrevistas, foram escolhidas três professoras, sendo uma de cada ano do Ciclo de Alfabetização. A escolha das professoras do $1^{\circ}$ e do $3^{\circ}$ ano ocorreu com base na observação das ações praticadas por elas em suas salas de aula: são professoras que procuram desenvolver um trabalho visando o atendimento de todos, aproximando-se, portanto, das ações de diferenciação pedagógica. No caso do $2^{\circ}$ ano, a escolha pela professora entrevistada não seguiu esse mesmo critério, pois em nenhuma sala de $2^{\circ}$ ano foi observada alguma ação que, de fato, se aproximasse das práticas diferenciadas de ensino.

Depois da estrutura geral da unidade, o primeiro aspecto observado na escola foi a organização das salas de aula: disposição de carteiras, agrupamentos de alunos e critérios de construção desses agrupamentos. De modo geral, observou-se que, em praticamente todas as classes - 9 das 12 salas observadas - a forma de organização da sala de aula era a mesma: a mesa do professor à frente e as carteiras organizadas em fileiras, uma após a outra, denotando uma concepção mais tradicional de ensino.

Essa forma de organização dificulta a realização do trabalho diferenciado na sala de aula, porque as interações entre os alunos ficam limitadas. Caso a organização fosse diferente (grupos, pares, duplas produtivas etc.), enquanto o professor atendesse um aluno que necessita de mais atenção em determinado momento, os demais alunos poderiam ir se ajudando, facilitando o próprio trabalho do docente. Essa interação fica mais difícil na configuração por fileiras, que geralmente é feita com a intenção de deixar a sala mais silenciosa. 
Em apenas três das doze salas observadas havia uma organização diferente, com os alunos sentados em duplas, seja de forma fixa ou para a realização de uma atividade específica. No caso de um dos $1^{\circ}$ s anos observados, os alunos eram organizados em duplas mistas: algumas de meninas e meninos, outras de meninas e meninas ou meninos e meninos.

Havia um $3^{\circ}$ ano que também adotava essa organização, mas, no caso desta classe, a professora permitia que os alunos se organizassem de forma mais livre em algumas atividades, deixando que eles escolhessem com quem trabalhar. Essa organização é um exemplo de agrupamento por duplas produtivas, visto que nestes pares sempre havia um aluno que estava mais avançado, que auxiliava o colega que possuía mais dificuldades, conforme relatado pela professora da sala.

Com relação às práticas de diferenciação pedagógica, a primeira forma observada foi a diferenciação de conteúdo/currículo. Observou-se que, em dez das doze salas observadas, o conteúdo aplicado aos alunos era exatamente o mesmo, em todas as atividades. Porém, em duas salas, uma de $1^{\circ}$ e uma de $3^{\circ}$ ano, as professoras adotavam um caderno à parte para os alunos que apresentavam dificuldades, com atividades de conteúdos diferentes dos abordados com o restante da sala. Mas, essa diferenciação de atividades ocorria apenas com alunos que tinham muita dificuldade, e que, por serem considerados alunos atrasados, demandavam um atendimento diferente por parte das professoras.

Com relação a essa prática, foram observadas duas situações. A primeira delas ocorreu em uma sala de aula de $1^{\circ}$ ano: o aluno fazia as atividades desse caderno, de acordo com seu nível de aprendizagem, não sendo cobrado pela atividade "comum" da sala. Na segunda situação, encontrada em uma sala de $3^{\circ}$ ano, o aluno fazia as atividades aplicadas a todos, e, além delas, recebia atividades específicas ao seu nível de aprendizagem para fazer em casa.

A diferenciação de práticas de ensino pode ser observada na maior parte das salas de aula, visto que os professores, de modo geral, conferem atendimentos diferentes aos alunos, conforme a necessidade de cada um. Porém, esse tipo de atendimento foi observado apenas com alunos que apresentavam dificuldades: esses alunos iam com mais frequência à mesa do professor, não apenas de forma espontânea, mas também quando eram chamados para receberem um acompanhamento diferenciado em alguma atividade.

É possível ver esse tipo de diferenciação sendo praticada pelo docente, porém, ela aparece como forma de "remediar" o ensino, e não como uma ação voltada para o atendimento de todos. Percebe-se que boa parte dos professores reconhece o caráter heterogêneo das salas de aula - conforme também mostram os dados dos questionários-, mas esse reconhecimento, 
na maioria das vezes, tem o olhar voltado para a dificuldade, e não para as diferenças de aprendizagem em si, o que é diferente.

Essa diferença existe porque, ter um olhar apurado para lidar com a heterogeneidade, em sala de aula, não significa atender apenas o aluno que está em dificuldades; mas, muito além disso, implica um trabalho adequado para atender também aquele aluno que está em um patamar de aprendizagem mais avançado e, muitas vezes, se vê desmotivado por não encontrar no ensino algo que lhe desafie, que lhe dê mais do que ele já tem.

Outro exemplo dessa concepção equivocada sobre diferenciar as práticas de ensino foi a ação encontrada na sala de $3^{\circ}$ ano: o tempo de atendimento dispensado aos alunos também variava, visto que a professora passava muito mais tempo com um determinado aluno, que apresentava mais dificuldades, do que com os demais.

É necessário lembrar, mais uma vez, que embora esse tipo de ação tenha ocorrido, com mais ênfase, no atendimento aos alunos que apresentavam dificuldade - o que não deixa de ser um bom indicativo quando se fala em combate ao fracasso escolar - a diferenciação do ensino não visa apenas o atendimento do aluno em dificuldades, mas de todos. E não foram observadas, por exemplo, ações para o trabalho com alunos mais avançados em termos de aprendizagem.

Uma das professoras entrevistadas, inclusive, quando questionada se havia um trabalho diferenciado com alunos que se encontravam em níveis mais avançados, afirma que a escola ainda deixa a desejar nesse quesito:

[...] porque se eles já têm essa propensão a ter uma coisa mais rápida, você tem que acabar tendo que mobilizar esses alunos de uma forma também diferenciada, né. E aí, ultimamente tem-se conversado sobre isso, mas acho que ainda tem sido feito muito pouco por esses alunos. Eu credito que tem sido feito muito pouco. (Prof ${ }^{a}$. do $3^{\circ}$ ano).

A escola sempre esteve acostumada a trabalhar com o aluno médio, conforme apontado por Roldão (2003) no início deste trabalho. Logo, o aluno que está aquém ou muito além do esperado para seu ano é um aluno que acaba tornando o trabalho do professor mais difícil. É de se compreender, portanto, que diferenciar o ensino não é uma tarefa fácil, exigindo que o professor tenha um olhar apurado com relação aos perfis e as necessidades dos alunos. Parece haver dificuldade, por parte dos professores, em conhecer as formas e os ritmos de aprender de cada aluno, especialmente em classes numerosas.

Durante as observações realizadas na escola, também não foram presenciadas ações de avaliação diagnóstica, por parte dos professores. Isso dificulta o conhecimento do nível exato em que cada aluno se encontra, o que torna praticamente inviável a realização de práticas reais 
de diferenciação pedagógica, visto que a avaliação diagnóstica permite que o professor encontre um ponto de partida para cada aluno, podendo planejar, dessa forma, a ação a ser desenvolvida para facilitar a aprendizagem de cada um.

Os professores observados reconhecem que desenvolver uma prática que considere as diferenças presentes entre os alunos não é uma tarefa fácil. A afirmação de que o trabalho com as diferenças exige mais do professor pode ser ilustrada na seguinte fala:

[...] eu vou precisar me empenhar mais, se é uma criança que tem dificuldade eu vou precisar buscar estratégias, materiais diferentes, estímulos diferentes, pra poder alcançar aquela criança, às vezes sim, porque: vai depender, eu vou precisar me empenhar mais, se é uma criança que tem dificuldade eu vou precisar buscar estratégias, materiais diferentes, estímulos diferentes, pra poder alcançar aquela criança. (Prof. ${ }^{a}$ do $1^{\circ}$ ano).

Desenvolver esse trabalho com cada criança dentro de uma sala com cerca de 30 alunos, de fato, é algo que exige muito empenho por parte do docente e da escola, como um todo, que deve oferecer as condições necessárias para facilitar as ações dos docentes.

A diferenciação de intervenção pedagógica diz respeito às diversas formas encontradas pelo docente para auxiliar os alunos em seu processo de aprendizagem. Considera-se, nesse caso, o atendimento a todos os educandos nos seus diferentes percursos de aprendizagem, determinantes da heterogeneidade presente na sala de aula. O significado de intervir de forma diferenciada pode ser definido como a implantação de diferentes estratégias, utilizadas pelos professores para atingir os objetivos propostos, quando uma determinada tática não deu certo. Notou-se que os professores observados, de modo geral, se esforçam muito para auxiliar os seus alunos.

Em um dos $2^{\circ}$ s anos observados, a professora circula entre as mesas e faz intervenções individuais para com os alunos, conforme a necessidade apresentada. Nos $3^{\circ} \mathrm{s}$ anos, notou-se que, em duas das classes observadas, as professoras buscavam formas alternativas de fazer os alunos avançarem em suas aprendizagens, fosse por meio de materiais concretos - como jogos, explicações diferentes e mais individualizadas -, ou, ainda, por meio da criação de situações que envolvessem toda a sala, de maneira que nenhum aluno fosse excluído da atividade e todos pudessem ser atendidos em suas necessidades.

A diferenciação de atividades pode ser relacionada à diferenciação de currículo/conteúdos. Uma das professoras faz referência à utilização de um caderno com atividades diferenciadas para alunos que apresentavam dificuldades. Esse tipo de prática foi encontrado com mais frequência nas salas dos $3^{\circ} \mathrm{s}$ anos, embora em uma sala específica de $1^{\circ}$ ano também tenha sido observada a diferenciação de atividades, quando a professora utilizava 
um caderno à parte para desenvolver atividades de alfabetização com os alunos que estavam com mais dificuldades.

Porém, mais uma vez, é preciso lembrar que as práticas de diferenciação realizadas pelos docentes são voltadas aos alunos que apresentam dificuldades em seu processo de aprendizagem, fugindo do intuito da diferenciação pedagógica, que consiste em criar situações de aprendizagem propícias a todos, independentemente do nível em que se encontrem.

O início do uso desse caderno ocorreu em uma semana de atividades de reforço, que envolveu apenas os alunos que ainda não estavam alfabéticos. Esses alunos foram convocados a comparecerem à escola em um período em que geralmente há muitas faltas, que é o início do mês de julho, uma semana antes do recesso escolar. Segundo a docente de um dos $1^{\circ}$ s anos observados, nesse período foram desenvolvidas atividades que tinham o intuito de alfabetizar os alunos que ainda não haviam alcançado esse objetivo.

Embora fossem trabalhados conteúdos diferentes com o objetivo de atender às necessidades dos alunos em questão, tal ação possui mais características de um período intensivo de reforço escolar, não refletindo a existência real de um entendimento mais amplo do conceito de diferenciação pedagógica por parte dos docentes.

A professora deste $1^{\circ}$ ano afirmou, em uma conversa informal durante as observações, que a iniciativa rendeu resultados extremamente satisfatórios, permitindo que se atingissem os objetivos que ainda não haviam sido alcançados. Porém, o ideal seria que aqueles alunos, que foram alfabetizados neste período intensivo de estudos, tivessem sido alfabetizados no mesmo período que os demais, o que seria possível, caso fossem desenvolvidas ações de diferenciação pedagógica com toda a classe, como prática diária do professor.

Com relação à diferenciação de materiais, esse tipo de ação pode ser encontrado especialmente nos $1^{\circ}$ s anos. Mas, também em uma das salas de $3^{\circ}$ ano, observou-se que a professora permitia e incentivava utilização de diversos materiais disponíveis, como jogos didáticos, letras móveis e jogo de memória, para facilitar a aprendizagem dos alunos com mais dificuldade, especialmente aqueles ainda não alfabetizados. Percebeu-se que, a utilização desses materiais incentivava muito os alunos, o que, segundo a professora da sala, estava trazendo bons resultados.

Não foi possível encontrar ações que caracterizassem a diferenciação de expectativas de aprendizagem nas salas de aula observadas. Havia apenas um indício de que a professora de um dos $1^{\circ} \mathrm{s}$ anos, que tinha uma criança portadora de necessidades especiais, não esperava desse aluno o mesmo resultado de aprendizagem que esperava do restante da sala. Por um lado, diferenciar as expectativas de aprendizagem pode ser benéfico, se forem considerados os 
diferentes estágios de aprendizagem em que se encontra cada criança, para, a partir deles, definir o que se pode esperar de cada um. Em contrapartida, pode-se incorrer no erro de minimizar as expectativas de aprendizagem de alunos que porventura se encontrem em níveis mais baixos, ou alunos que apresentem necessidades especiais.

Com relação aos produtos de aprendizagem, também não foram presenciadas ações relacionadas a esse tipo de diferenciação durante as observações. O que se notou foi que havia diversos trabalhos feitos pelos alunos, como quadros e cartazes informativos, afixados pelas paredes da escola, o que permite supor que essa seja uma forma de incentivar os alunos a desenvolver e expor os frutos obtidos com sua aprendizagem. Mas, a exposição dos trabalhos, por si só, não denota, necessariamente, que os docentes compreendam que os alunos podem expressar suas aprendizagens por meio de produtos diversos. A iniciativa tampouco evidencia a existência de um tipo de ação diferenciada. Vale ressaltar, também, que muitas vezes, os resultados obtidos pelas crianças ficam limitados às provas aplicadas periodicamente.

Com relação às diferenças existentes entre os alunos, as observações apontaram que as professoras compreendem que elas estão muito presentes no cotidiano escolar, constituindo a individualidade dos alunos. Elas afirmam, como exemplo dessas diferenças, que há alunos mais participativos e há alunos mais tímidos, e para cada um deles será necessário desenvolver uma forma de trabalho, que atenda às suas necessidades educativas.

Porque tem crianças que, é a característica da criança mesmo né, essas
diferenças existem sim, mas eu acho que cabe ao professor envolver, trazer
pra perto, estimular, e "vamos lá", e "vamos fazer", "vamos aprender", e
quando... é difícil falar de diferença né, porque tem a individualidade de cada
criança. (Prof. do $1^{\circ}$ ano) Outra fala que demonstra o reconhecimento da necessidade de se atribuir um olhar diferenciado, conforme a necessidade dos alunos, pode ser observada a seguir:

[...] pra cada criança uma abordagem, um olhar. Embora seja um grupo muito grande, mas você tem que ter essa diferenciação, esse olhar. Diferenciação no bom sentido, que aí você vai olhar cada um como realmente é, como é, pra que você também possa produzir melhor alguma coisa em prol daquela criança, senão fica bem complicado. (Professora do $3^{\circ}$ ano).

Nestas falas, percebe-se que os professores não atribuem as diferenças apenas aos alunos com necessidade especiais ou com dificuldades, tal como foi visto em parte dos depoimentos presentes nos questionários, nos quais os respondentes, embora concordassem que os alunos não são iguais, relacionavam essas diferenças à questão da dificuldade ou da necessidade educativa especial. 
Todavia, quando questionados especificamente, se percebem diferenças entre os alunos, e a que as atribuem, nota-se que, a percepção que os docentes entrevistados têm com relação às diferenças existentes entre os alunos não é igual. No $1^{\circ}$ ano, a professora afirma que a diferença que percebe em seus alunos é "muitas vezes só de maturidade, por conta da idade mesmo".

Já a docente entrevistada, do $3^{\circ}$ ano, afirma que as diferenças existentes entre os alunos se devem ao meio em que eles vivem. Esta fala, especificamente, retrata uma maneira muito particular de compreensão do significado da diferenciação, reproduzindo a relação que a professora faz com a discussão sobre desigualdades sociais e diferenças, não demonstrando compreensão das diferenças inerentes à aprendizagem em si.

As observações mostraram que a escola se esforça por desenvolver um trabalho que possibilite o atendimento de todos, considerando as diferenças presentes entre os alunos. Quando questionada a respeito da existência de ações que visavam o atendimento de todos os alunos, a docente entrevistada, do $3^{\circ}$ ano, afirma que a escola tem uma preocupação na inclusão de todos: "por isso que me identifico muito, porque é uma escola que trabalha muito com projetos. Eu acredito que eles buscam um meio de tentar incluir a todos aqui”.

Dentre as ações realizadas, é citada a existência de programas de reforço na unidade escolar:

Aqui dentro da escola mesmo tem programas pra gente tentar fazer com que o aluno... Então tem um reforço, tem uma recuperação continuada, aquele reforço continuado, isso tem. Pra gente tentar, de alguma forma fazer eles se integrarem mais, tem tudo isso (Profa. do $3^{\circ}$ ano).

Porém, considerando os propósitos da diferenciação pedagógica, iniciativas de reforço escolar não estão, necessariamente, ligadas a estas ações, inclusive pelo fato de que o reforço é uma atividade direcionada aos alunos que apresentam dificuldades de aprendizagem, não incluindo outras necessidades existentes nas salas de aula.

Considerando a questão da adaptação do professor à realidade dos educandos, e o atendimento das necessidades educativas dos mesmos, uma das entrevistadas afirma que escuta e acolhe as experiências trazidas pelos alunos, ainda que isso signifique "fugir" dos conteúdos programados para a aula.

A questão de partir da realidade do aluno, mesmo sendo importante para motivar a aprendizagem, não configura, por si só, uma ação de diferenciação pedagógica. A fala citada demonstra o entendimento de que, se o professor estiver disposto a ouvir o que o aluno tem a dizer, se considerar os seus interesses, já está diferenciando. Mas, apenas isto não basta. Conforme aponta Perrenoud (1999), diferenciar o ensino implica em ensinar de forma que os 
alunos estejam sempre diante de situações favoráveis para sua aprendizagem, e apenas considerar os interesses do aluno não é suficiente; trata-se de modificar a própria organização da escola e do professor, mobilizando materiais, estratégias, formas diferentes de ensinar que permitam o avanço de todos.

A gestão da escola se mostrou bastante preocupada com o desempenho de seus alunos, participando e acompanhando ativamente o trabalho dos professores. Na entrevista realizada com as duas coordenadoras pedagógicas da unidade, fica evidente o empenho de toda a unidade para alcançar bons resultados. As gestoras citam o desenvolvimento de ações de apoio e orientação aos docentes, bem como a cobrança do trabalho realizado com os alunos. Os professores confirmam as ações dos gestores ao afirmarem que a escola acompanha de perto todo o trabalho realizado, cobrando resultados, auxiliando e orientando os docentes quando necessário.

Porém, quando se questiona que ações são feitas, pela escola, no intuito de atender as diferenças individuais presentes nos alunos, a resposta dada pelas gestoras não denota o desenvolvimento de ações diferenciadas. São citadas ações de reforço escolar e os projetos desenvolvidos pela escola, tal como mencionado pelas professoras entrevistadas. $\mathrm{O}$ fato de citar o reforço escolar, quando se fala em diferenças entre os alunos, demonstra o entendimento, por parte da gestão, de que o diferente é aquele que tem dificuldade. Por mais que se enfatize as diferenças inerentes a todos os sujeitos, os agentes entrevistados sempre recaem na questão do aluno que tem dificuldades.

Quando questionadas, se as ações realizadas na escola, com o intuito de atender as diferenças cognitivas para fazer com que todos aprendam, têm alguma fundamentação teórica específica, as gestoras fazem referência ao construtivismo, tal como alguns docentes apontam no questionário. Ou seja, não há referência direta à diferenciação pedagógica por parte da gestão da escola pesquisada.

Também foram feitas algumas tentativas de se ter acesso ao Projeto Pedagógico da escola, porém, sem sucesso, visto que um dos membros da gestão afirmou que o documento estava indisponível.

Finalizando a análise, pode-se concluir que, embora seja uma escola organizada, que possui profissionais competentes e uma gestão séria e comprometida em propiciar um processo de ensino e aprendizagem que atenda às necessidades de seus alunos, não é possível afirmar que a escola desenvolve, de fato, um trabalho de diferenciação pedagógica.

Mesmo considerando a existência das diferenças presentes entre os alunos e se preocupando com o atendimento de todos, a gestão não tem clareza do que, de fato, é a 
diferenciação pedagógica, assim como grande parte das ações desenvolvidas pelos docentes não podem ser consideradas práticas de diferenciação pedagógica.

A análise presente neste capítulo mostrou a existência de algumas ações condizentes com as práticas de diferenciação pedagógica, mas essas ações são minoria em vista do que foi relatado.

E, dentre as ações condizentes com as práticas de diferenciação pedagógica, uma parcela considerável é desenvolvida considerando o atendimento do aluno com dificuldade ou que seja portador de alguma necessidade especial. Portanto, seria um equívoco afirmar que a escola adota a diferenciação pedagógica como princípio norteador de suas práticas. 


\section{CAPÍtULO IV}

\section{ANÁLISE E DISCUSSÃO DOS RESULTADOS COM BASE NA BIBLIOGRAFIA}

Neste capítulo são analisados os aspectos mais relevantes das observações de campo, à luz da bibliografia sobre diferenciação pedagógica, que embasa esta pesquisa. Os dados obtidos, com a aplicação dos questionários e com as observações realizadas na escola, trouxeram elementos importantes para pensar a diferenciação pedagógica e sua possível aplicabilidade na rede municipal de ensino de São Paulo.

Embora a pesquisa tenha sido realizada com um universo pequeno de educadores da rede municipal, a quantidade de respostas obtidas possibilitou apreender o quanto a noção de diferenciação pedagógica é conhecida entre os educadores, se pode ser encontrada em suas práticas e qual o teor das ações desenvolvidas.

\section{IV.1 - Conhecimento docente sobre diferenciação: embasamento teórico ou intuição?}

Os dados obtidos mostraram que, uma boa parcela dos professores que participaram da pesquisa, ao serem questionados sobre o conhecimento dos diferentes termos que se referem ao conceito de diferenciação pedagógica, demonstram ter noção do que eles significam, trazendo ideias totalmente pertinentes ao assunto abordado.

No entanto, os depoimentos indicam que esse conhecimento não parece estar fundamentado na teoria que embasa a diferenciação pedagógica: em nenhum momento são citados autores que trabalham o tema, nem cursos que possam ter apresentado o assunto aos docentes.

As expressões pedagogia diferenciada, diferenciação pedagógica, práticas diferenciadas de ensino já sugerem ou fornecem pistas do que trata, permitindo que o docente dê uma definição próxima ou até mesmo de acordo com o real significado das expressões apresentadas, quando questionado acerca de seu entendimento sobre as mesmas, sem que necessariamente as conheça em termos teóricos.

Dessa forma, pode-se afirmar que os próprios termos utilizados na pesquisa permitiram que os docentes fornecessem respostas de acordo ou próximas do que a bibliografia define como práticas diferenciadas de ensino. 


\section{IV.2 - Reconhecimento das diferenças}

Os professores, em sua grande maioria, reconhecem que os alunos são seres singulares, únicos em interesses, motivações, formas de aprender, e oriundos de realidades sociais diversas. Além de reconhecerem essa diversidade, consideram importante a realização de um trabalho que leve em conta essas diferenças. Corroborando a ideia da importância de se considerar as diferenças presentes entre os alunos, Perrenoud (2000) afirma que:

[...] a preocupação de ajustar o ensino às diferenças individuais não surge somente do respeito às pessoas e do bom senso pedagógico. Ela faz parte de uma exigência de igualdade: a indiferença às diferenças transforma as desigualdades iniciais, diante da cultura, em desigualdades de aprendizagem e, posteriormente, de êxito escolar (PERRENOUD, 2000, p. 9).

Quando são ignoradas as diferenças entre os alunos, o ensino ministrado possibilita o êxito dos que já são culturalmente favorecidos. Ao mesmo tempo, observa-se o fracasso dos que não dispõem destes mesmos recursos, os quais acabam convencidos de que são incapazes de aprender, atribuindo seu fracasso a uma suposta insuficiência pessoal. A escola seria, assim, isentada desta responsabilidade (PERRENOUD, 2000).

Todavia, mesmo que os docentes reconheçam e defendam a importância de se desenvolver um trabalho pedagógico voltado para o atendimento das classes heterogêneas, a maioria dos professores que pratica alguma forma de diferenciação pedagógica na pesquisa, relaciona esse tipo de ação ao atendimento de alunos com dificuldades escolares ou portadores de necessidades especiais, fugindo do real propósito da diferenciação do ensino, que é permitir que todos os alunos estejam diante de situações que favoreçam o seu aprendizado.

Considerando que as salas de aula são compostas por alunos muito diferentes entre si seja em ritmo de aprendizagem, nível de desenvolvimento, interesses, influências socioculturais, - o objetivo da diferenciação é atender às necessidades educativas de todos, de modo que cada um possa traçar seus próprios caminhos de aprendizagem e alcançar o sucesso escolar, permitindo "que todos os alunos possam aprender e progredir a despeito de suas diferenças" (MAINARDES, 2007, p. 6).

Isso quer dizer que todos os educandos necessitam de um atendimento que busque promover o sucesso: alunos com dificuldades, alunos com níveis mais avançados, superdotados, alunos considerados medianos. Focar a diferenciação pedagógica apenas nos alunos com mais dificuldades e/ou em alunos que possuem algum tipo de necessidade especial 
não deixa de ser uma forma de exclusão. O objetivo é fazer com que todos sejam beneficiados em suas aprendizagens, e não apenas um grupo específico.

\section{IV.3 - O foco na dificuldade e a falta de atenção às demais diferenças}

É certo que o estudo sobre diferenciação pedagógica surge da preocupação com o fenômeno crescente de fracasso de aprendizagem nas escolas, o que, inevitavelmente, acabava por recair nos alunos com mais dificuldades, oriundos, geralmente, das classes mais baixas. De fato, é necessário ter um olhar especial para esses alunos, considerando que eles são a maior parcela dos que fracassam na escola. Perrenoud (1999) afirma que é necessário dar mais aos que tem menos, para que estes possam competir de forma igualitária com os demais.

Porém, conforme já ressaltado, as ações de diferenciação pedagógica não devem se ater apenas aos alunos com dificuldades. Hall, Strangman e Meyer (2002) defendem que todos os alunos possuem formas e ritmos diferentes de se desenvolver, o que pressupõe o desenvolvimento de ações diferenciadas para todos. Por mais que se dê uma atenção especial aos alunos que apresentam alguma defasagem, ao mesmo tempo, devem ser desenvolvidas atividades, intervenções e práticas que atendam aos demais.

Os autores que dissertam sobre a diferenciação pedagógica pressupõem esse tipo de ação ao defender o trabalho em grupos. Nessa configuração, o professor organiza a sala em grupos mistos, não necessariamente com alunos do mesmo nível trabalhando juntos, para que, enquanto ele trabalha auxiliando um aluno que necessita de uma intervenção mais próxima, os demais possam ir auxiliando uns aos outros no que for necessário.

Mas, o que se encontrou na escola pesquisada foram professores que quase nunca permitem que os alunos trabalhem em grupo. Apenas em três salas de aula foi possível observar uma configuração diferente e, ainda assim, os alunos não estavam organizados em grupos maiores, mas, no máximo, em duplas, o que ocorria apenas em alguns momentos ou atividades.

Outra questão importante a ser discutida é que falta atendimento para os alunos mais avançados. Uma das docentes entrevistadas afirma que é necessário dar atenção aos alunos com dificuldades, mas que, em contrapartida, os alunos mais avançados têm sido deixados de lado, o que é relatado no depoimento a seguir:

[...] a gente tem que pensar muitíssimo nos alunos que tem problemas de aprendizado, tudo mais. E nisso sempre é feito um acompanhamento muito frequente. Agora, e aqueles alunos que são maravilhosos, que são ótimos, será 
que a escola também está deixando a desejar? Poderia estar trabalhando outro tipo de coisa com esses alunos também [...] porque às vezes você fica batendo na mesma tecla com aqueles alunos que têm dificuldade de aprendizado; quando você olha pra aqueles que são um número bem menor, mas que são "top", fica com aquela carinha de tédio, e aí você tem que dar coisas diferentes pra eles fazerem, e cada vez instigá-los mais. E aí, ultimamente tem-se conversado sobre isso, mas acho que ainda tem sido feito muito pouco por esses alunos. Eu credito que tem sido feito muito pouco. (Professora do $3^{\circ}$ ano, Escola IQ7).

Se, por um lado a discussão sobre o atendimento de alunos com dificuldades é algo recorrente no meio educacional - o que foi constatado nas falas de diversos participantes da pesquisa, por outro lado, o aluno mais avançado quase nunca é lembrado. A escola espera lidar com um aluno que constrói seu conhecimento de forma linear e está sempre acompanhando o nível trabalhado pelo professor.

Uma situação semelhante à dificuldade de progredir, que muitos alunos experimentam em salas de aula, nas quais se trabalha de forma homogênea, pode ser encontrada nos escritos de Mainardes (2007). Ao relatar a implantação de uma experiência de diferenciação pedagógica em uma escola municipal em Ponta Grossa, Paraná, o autor afirma que, na unidade em questão, as atividades aplicadas nas salas de aula eram a mesmas para todos, de forma que apenas um grupo de alunos era atendido, conforme suas necessidades de aprendizagem. Assim, os alunos que tinham mais dificuldades ficavam inquietos por não conseguirem desenvolver o que lhes era proposto, e os mais avançados se sentiam entediados por já conhecerem o que era apresentado.

Corroborando com a ideia de atendimento a um aluno mediano, que pode ser definido como um aluno que não está nem abaixo, nem muito acima do esperado para seu ano, Roldão (2003), afirma, justamente, que a escola foi concebida para atender um aluno médio. Dessa forma, tudo o que foge deste padrão - seja a dificuldade ou o avanço em relação aos demais parece ser encarado como um problema. No caso do que foi constatado a partir das observações realizadas neste trabalho, essa ideia é reforçada com o fato de que muitos dos docentes que participaram da pesquisa associam as práticas de diferenciação ao atendimento de alunos com dificuldades, por considerarem que deverão desenvolver atividades extras, intervenções diferentes, dentre outras ações para que esses alunos possam alcançar o que lhes é proposto.

Além do fato de a escola se organizar para o trabalho com um aluno médio, Mainardes (2007) afirma que existe uma forte tendência nas práticas dos professores de propor atividades iguais para todos os alunos, desconsiderando que as classes são compostas por alunos de diversos em níveis cognitivos e necessidades de aprendizagem. 
Ainda sobre a organização das instituições escolares, bem como a forma que as mesmas tratam seus alunos, Pacheco (2008) afirma que, de um lado, a escola possui um papel de inclusão, seja por razões políticas, econômicas, sociais; por outro, ela assume um papel excludente, visto que um dos pilares que a sustenta é hierarquização que nela se pratica. É no sentido de combater a exclusão presente em muitas escolas, que se defende a inserção de práticas diferenciadas nas salas de aula, considerando que tais ações têm como princípio o atendimento das necessidades educacionais de todos os alunos, independentemente de sua condição social, combatendo, portanto, a criação de hierarquias entre os alunos.

Conforme já citado na Introdução deste trabalho, a escola assume o papel de inclusão quando democratiza o acesso a todos. Porém, somente a garantia do acesso não resolve o problema se não forem dadas condições de progresso a todos. Neste sentido, Pacheco (2008) afirma que:

No DNA da escola está inscrita, de modo bem marcante, a exclusão, tornandose quase impossível colocá-la a funcionar de uma forma totalmente democrática, já que exterior e interiormente a igualdade é conjugada com a diferença. (PACHECO, 2008, p. 179).

Considerando o papel das instituições escolares junto a seus alunos, pressupõe-se que a diferenciação pedagógica deveria ser parte constante do próprio projeto pedagógico da escola, a fim de não reproduzir as desigualdades que há tempo vêm sendo mantidas.

O sucesso da diferenciação pedagógica não é algo que depende apenas do professor (PERRENOUD, 2000). Embora o professor seja uma peça fundamental para a concretização dessa prática de ensino, a mudança das formas de ensinar deveria começar pela própria instituição escolar, que poderia adotar a diferenciação pedagógica como princípio de trabalho. Dessa forma, a diferenciação pedagógica seria uma prática da escola como um todo, e não apenas de alguns professores, caracterizando ações isoladas, tal como mostraram os dados da pesquisa.

A pesquisa de campo deste trabalho mostrou que, na escola observada, as poucas ações que possuíam um caráter voltado para a diferenciação do ensino eram praticadas isoladamente por alguns professores, não constituindo os princípios pedagógicos da instituição.

Se a diferenciação pedagógica constituir o princípio pedagógico escolar, os professores terão a quem recorrer quando precisarem de apoio, recursos e orientações para o desenvolvimento de um trabalho tão complexo, como é a diferenciação, mas capaz de favorecer a mudança dos cenários de exclusão presentes nas escolas. 
E vale lembrar, mais uma vez, que a exclusão não é apenas dos alunos com dificuldades, mas de todos aqueles que, de alguma forma, se sentem excluídos e desmotivados por não terem suas expectativas e necessidades educacionais atendidas.

\section{IV.4 - Equívocos sobre as práticas de diferenciação}

As informações obtidas com os questionários e com as observações mostraram que muitas das práticas definidas como sendo de diferenciação pedagógica, na verdade, são assim definidas de modo equivocado.

Como exemplo disso, é possível citar as atividades direcionadas, na escola da pesquisa de campo, apenas para um grupo de alunos que não estavam alfabetizados, e que foram desenvolvidas quando a frequência nas aulas estava reduzida, devido à proximidade do recesso escolar.

Esta prática, na verdade, não pode ser considerada uma ação diferenciada, mas sim, uma ação de reforço escolar intensivo, desenvolvido com um grupo específico de alunos. A diferenciação pedagógica pressupõe um trabalho que vá além do atendimento a grupos específicos. Conforme aponta Perrenoud (1999) não se trata de dar aulas individuais a cada um dos alunos, mas de permitir uma organização que facilite o desenvolvimento de ações diferenciadas que atendam às necessidades de todos.

\section{IV.5 - A dificuldade de se desenvolver um trabalho pedagógico diferenciado}

Alguns dos professores que participaram da pesquisa mencionaram a dificuldade de trabalhar de forma diferenciada, tendo em vista a atual configuração do ensino na rede municipal. Os docentes consideram que o número de alunos nas salas de aula é um fator que dificulta o trabalho diferenciado. Além do entrave do alto número de alunos, alguns docentes apontam que o fato de ter que desenvolver diferentes intervenções no grupo é um dificultador para a concretização das práticas de diferenciação pedagógica.

Os depoimentos obtidos em campo coadunam com a afirmação de Mainardes (2007) de que a implantação da diferenciação pedagógica nas escolas é um desafio. Os professores necessitam de orientação, auxílio e estímulos frequentes para que sejam capazes de colocar em prática essa configuração de ensino. O autor afirma, ainda, que se os docentes não receberem um apoio adequado e contínuo, "poderão sentir-se ainda mais sobrecarregados de funções e tarefas" (2007, p. 7), visto que a diferenciação das práticas pedagógicas requer especial esforço no preparo e desenvolvimento de atividades, materiais e intervenções por parte do professor. 
A realidade é que justamente os docentes não recebem formação para trabalhar de forma diferenciada, nem nas licenciaturas, responsáveis por sua formação inicial, tampouco nos cursos de formação contínua. Essa realidade é atestada por Perrenoud (2000) que afirma que nenhuma instituição de formação de professores, nem nos países europeus, fornece subsídios suficientemente adequados para capacitar os professores a praticar a diferenciação pedagógica. Se os professores, que são um dos principais agentes colaboradores para o aprendizado dos alunos, não receberem apoio e orientações naquilo que têm dificuldade e, mais ainda, na realização de uma prática que não é comum, é possível que em vez de aumentar o rendimento da sala, ocorra exatamente o contrário.

Faz-se necessário que o tema da diferenciação pedagógica se torne uma pauta primordial nas discussões educacionais, sendo dever das instâncias superiores em educação incluí-lo nas grades dos cursos de Pedagogia e nos cursos de formação continuada e aperfeiçoamento. A teoria e a prática são indissociáveis: para se desenvolva uma boa prática, é necessário haver um embasamento teórico consistente que norteie as ações. Por esse motivo, não é de se espantar que os professores não estejam desenvolvendo práticas de diferenciação tal como preconizado pela bibliografia que disserta sobre o tema em estudo.

\section{IV.6 - O currículo na perspectiva diferenciada de ensino}

As observações mostraram que os professores quase nunca afirmam desenvolver práticas de diferenciação de conteúdos/currículos. Existem algumas ações neste sentido, mas são poucas, e geralmente estão voltadas para alunos com necessidades especiais ou com dificuldades.

Uma questão muito importante de ser discutida com base nas observações realizadas diz respeito à questão do currículo das escolas. Tomlinsom (2003) afirma que um dos princípios para promover a equidade e a excelência entre alunos que são academicamente diferentes é, em primeiro lugar, definir um bom currículo, que seja coerente, importante, convidativo e que estimule o aluno a pensar.

Acredita-se, nesta pesquisa, que o currículo deve ser o mesmo para todos, pois, se os conteúdos ministrados aos alunos forem diferenciados, conforme as aptidões de cada um, é provável que alguns fiquem defasados em relação aos conhecimentos ofertados, visto que o professor poderá privar alunos que se encontrem em níveis menos avançados de certos conhecimentos, que julgará impossíveis de serem alcançados por eles. Neste sentido, Santos (2009) aponta que: 
[...]fazer um ensino dirigido a todos não é, como por vezes se diz, "baixar o nível de exigências", mas sim fazer uma gestão curricular que tenha presente que os alunos não aprendem todos do mesmo modo, nem as suas dificuldades são as mesmas. É, sim, procurar ajustar as práticas de ensino aos alunos que se têm, às suas características pessoais e colectivas, aos seus pontos fortes e menos conseguidos. Tal, requer, evidentemente, um conhecimento profundo sobre os alunos e o conhecimento e o domínio de múltiplas estratégias de ensino (SANTOS, 2009, p. 3).

A diferenciação curricular ou de conteúdos é uma das possibilidades previstas nas práticas diferenciadas de ensino. É perfeitamente possível que se diferencie o currículo, variando os conteúdos aos quais os alunos terão acesso, conforme seus interesses e suas necessidades, especialmente considerando-se um aluno deficiente, que não conseguirá acompanhar o currículo proposto da mesma forma que os demais.

Porém, têm-se a hipótese de que, a utilização desta forma de diferenciação do ensino, com alunos considerados "normais", pode levar à diminuição da aprendizagem, visto que o docente poderá reduzir as informações disponibilizadas para alguns alunos por considerá-los menos capazes. Além disso, acredita-se que a definição e garantia de um currículo mínimo, comum a todos, assegurará que o aluno não fique defasado, caso migre para qualquer outra região do país, por exemplo. Sabe-se que cada local possui uma especificidade, que deve também ser contemplada no currículo. Porém, o que aqui se defende é que haja uma base comum à qual todos tenham acesso.

Dessa forma, justifica-se que, o que deve diferenciar-se é a forma pela qual os alunos se apropriarão destes conteúdos, considerando-se os diversos percursos que eles constituirão, em suas trajetórias escolares, para alcançar os conhecimentos propostos. Segundo Tomlinsom (2003), todas as tarefas devem respeitar cada aluno, que merece desenvolver um trabalho centrado no conhecimento, compreensão e habilidades essenciais.

O desenvolvimento de ações de diferenciação pedagógica requer um bom preparo por parte dos professores, visto que a formação docente é ainda deficiente, no que diz respeito ao desenvolvimento de ações da complexidade da diferenciação. Mas isso não significa que tudo deva recair sobre esses profissionais.

Ao que tudo indica, não há uma discussão sólida sobre diferenciação pedagógica estabelecida no meio educacional, visto que, em nenhum momento, os docentes citam autores que dissertam sobre o tema, ou os documentos oficiais, que legislam sobre a educação no país, citam a diferenciação pedagógica. Embora existam produções importantes sobre o assunto no meio educacional brasileiro (ANDRÉ, 2006; MAINARDES, 2007), a maior parte dos teóricos que tratam do tema é de origem estrangeira. 
Essa é uma das hipóteses, que explica o fato de os docentes não se apoiarem em nenhum referencial teórico para fornecer definições, sobre o que entendem, pelas expressões elencadas, para se referir às práticas de diferenciação pedagógica. A falta de referencial teórico e discussões sobre o tema, também, parece ser um motivo pelo qual as ações que os docentes definem como sendo de diferenciação, muitas vezes, não o são, como é o caso do exemplo da semana de reforço com os alunos do $1^{\circ}$ ano.

Isso não quer dizer que os docentes não se preocupem com o aprendizado de seus alunos, visto que foram encontradas muitas tentativas válidas de fazer com que os alunos progridam, desenvolvidas por professores empenhados e comprometidos. Porém, como o objetivo deste trabalho é buscar a existência de práticas específicas de diferenciação, seria ilegítimo afirmar que as ações desenvolvidas estão plenamente de acordo com aquilo que esperava encontrar.

Outro fator importante de se levar em consideração, quando se fala em diferenciação pedagógica, é o contexto educacional de cada país. Alguns países europeus já se organizam, há muito tempo, para o desenvolvimento de ações diferenciadas, o que não é o caso do Brasil. Por esse motivo, há de ser feito um trabalho exaustivo para incluir ações de diferenciação pedagógica nas políticas educacionais do país. 


\section{CONSIDERAÇÕES FINAIS}

Esta pesquisa teve como objetivo investigar a existência de práticas de diferenciação pedagógica na rede municipal de ensino de São Paulo e, também, analisar o teor dessas ações. Buscou-se compreender o conhecimento deste conceito pedagógico entre os docentes, assim como a apreensão que estes profissionais têm sobre ele. Outrossim, o estudo teve ainda como objetivo, encontrar referências sobre a diferenciação pedagógica, em alguns documentos oficiais, que legislam sobre a educação brasileira.

A análise dos dados obtidos com a pesquisa de campo, à luz da bibliografia que embasou o trabalho, permitiu que se fizessem afirmações a respeito da situação do atendimento dos diversos perfis de alunado presentes nas salas de aula, contribuindo para a compreensão da questão do combate ao fracasso escolar, com base em uma pedagogia diferenciada.

Dentre outros objetivos, o estudo buscou investigar a existência de referências à diferenciação pedagógica, em documentos oficiais que legislam sobre a educação no país. Como resultado da investigação, têm-se que a proposta da diferenciação pedagógica não se faz presente de forma explícita em todos documentos analisados nesta pesquisa. Existe, sim, o reconhecimento da necessidade de se considerar as diferenças de diversas ordens presentes entre os alunos, para que se possa assegurar uma educação que inclua a todos. Mas que a questão específica do trabalho pedagógico diferenciado é citada de forma indireta em parte das legislações analisadas. Também os docentes não citam referências teóricas para explicar ao que entendem pelo conceito de diferenciação pedagógica.

Esperava-se que os programas de formação desenvolvidos no âmbito da alfabetização, como é o caso do PNAIC, fossem indutores de um olhar voltado ao desenvolvimento de ações diferenciadas de ensino. Todavia, não foi isso o que a pesquisa mostrou, visto que, conforme já dito, a começar pelos documentos oficiais que dissertam acerca da educação no país, não foram encontradas referências diretas sobre práticas de diferenciação pedagógica. Também não foram localizadas possíveis menções a autores que discutem a diferenciação pedagógica no Brasil.

Porém, ainda que não haja citação de autores, os dados obtidos com a pesquisa de campo mostraram que os apontamentos feitos pelos docentes sobre a diferenciação pedagógica trazem definições coerentes sobre o conceito apresentado, indo ao encontro das ações diferenciadas preconizadas pela teoria que embasou este trabalho. Conforme mostrou o Capítulo IV, os participantes relacionam a importância de um ensino diferenciado com o atendimento dos 
diferentes perfis de alunos que compõem as redes de ensino, para que seja possível promover uma educação de qualidade.

Existe um esforço, por parte de alguns profissionais, no atendimento das necessidades educativas de seus alunos, procurando assegurar que os direitos de aprendizagem, propostos para cada ano, sejam alcançados por todos, colaborando com a promoção de uma educação de qualidade.

No caso da unidade escolhida para o aprofundamento do estudo, os resultados obtidos com as observações mostraram que a diferenciação pedagógica não se constitui como princípio pedagógico da escola. Embora a gestão monitore constantemente as ações dos docentes, procurando auxiliá-los e orientá-los nas situações em que encontram dificuldades, empenhando-se, ainda, para desenvolver um trabalho que inclua todos os alunos, constatou-se, entretanto, que esse acompanhamento não é voltado para o desenvolvimento de ações de diferenciação pedagógica.

Mesmo com as limitações deste estudo, as informações obtidas com os questionários, bem como as observações realizadas na escola permitiram compreender algumas possibilidades e limites da diferenciação pedagógica para o combate ao fracasso escolar.

Em primeiro lugar, fica evidente o reconhecimento, por parte dos docentes, de que não é possível trabalhar da mesma forma com todos os alunos. As diferentes formas de aprender e se desenvolver, os diferentes ritmos dos alunos, assim como os diferentes níveis cognitivos presentes em uma mesma sala de aula demandam uma atenção diferenciada e ações que privilegiem e atendam às necessidades inerentes a cada sujeito, sem discriminar ninguém.

Esse reconhecimento, por si só, pode ser considerado um bom começo para a efetivação das mudanças de que o ensino necessita. Se antes, o bom aluno era considerado o aluno mediano, hoje existe uma concordância, por parte dos professores, de que o ser humano possui aptidões e interesses muito diversos, e a educação deve procurar suprir as necessidades apresentadas para promover o sucesso na aprendizagem.

Porém, para além do reconhecimento das diferenças entre os alunos, que já é algo discutido pelos docentes, deveriam ser implantadas políticas de formação, que discutissem a introdução de novas formas de ensino, como a diferenciação pedagógica, visando alcançar o sucesso de todos. Um exemplo é a experiência realizada em Ontário, Canadá, onde as autoridades educacionais empenharam um esforço grande, em termos de implementação de políticas de formação docente, para prepararem professores para a aplicação de práticas diferenciadas nas escolas, adotando este modelo em toda a rede estudada (MORICONI, 2017). 
Talvez seja difícil a adoção do mesmo modelo em um país de grandes proporções como o Brasil, e vale lembrar que a ação descrita foi desenvolvida em apenas uma província do Canadá. Porém, a inserção do debate sobre diferenciação pedagógica nas pautas educacionais brasileiras é um ponto primordial para o início da capacitação docente para o trabalho pedagógico diferenciado.

Considerando que o reconhecimento das diferenças cognitivas e sociais entre os alunos é um dos princípios basilares para a consolidação de uma pedagogia diferenciada nas escolas, cabe também uma reflexão acerca da diferenciação de currículos e objetivos de aprendizagem. Conforme já discutido, acredita-se, nesta pesquisa, que a diferenciação de currículos/conteúdos é algo que exige muita cautela, porque existe o risco de o professor reduzir as aprendizagens de alguns alunos por considerar que eles são menos capazes. Isso não quer dizer que essa forma de diferenciação não possa ser benéfica, mas apenas em casos específicos, como, por exemplo, com alunos que possuem necessidades especiais e que, comprovadamente, não terão condições de atingir os mesmos patamares que os demais, devido a possíveis limitações físicas e/ou intelectuais.

Retomando a questão de que os alunos não são iguais, reitera-se que este reconhecimento por parte dos professores, por si só, não é suficiente para que as práticas docentes sejam modificadas por completo. As dificuldades com que os docentes se deparam para desenvolver um atendimento pedagógico diferenciado são mais um indício de que a diferenciação pedagógica ainda não ganhou muito espaço nas discussões e políticas educacionais brasileiras, e nem nas teorias educacionais, considerando que são poucos os autores que brasileiros que tratam desta teorização.

Ora, se nem as instâncias superiores que regem o ensino no país, nem a bibliografia de referência consolidaram uma discussão consistente, sobre essa forma de combate ao insucesso escolar, será ainda mais difícil que os professores, que recebem as orientações desses órgãos e, muitas vezes, se embasam na literatura educacional para desenvolverem suas práticas, estejam preparados para discutir e colocar tais ações em prática.

As condições de trabalho docente também interferem na concretização de uma pedagogia diferenciada nas escolas. O trabalho diferenciado exige esforço e preparo muito maiores por parte do professor, que, muitas vezes, se vê desmotivado para intervir conforme a necessidade de 30 alunos diferentes, especialmente no caso de professores que cumprem jornada dupla, tendo o tempo de estudo e preparo de aulas reduzidos. Um fator a ser considerado é que existem, ainda, muitos professores contratados na rede municipal, ou seja, aqueles que não acessaram o cargo por meio de concurso, o que dá ainda menos segurança ao docente. Além 
disso, professores contratados recebem menos do que os docentes efetivos, o que pode constituir um fator de desmotivação para o trabalho.

A questão da jornada docente também é um fator que pode dificultar o desenvolvimento de ações diferenciadas de ensino. Na rede municipal de São Paulo, existem, basicamente, dois tipos de jornada de trabalho: a Jornada Básica Docente, na qual o professor cumpre apenas o horário destinado ao trabalho com os alunos; e a Jornada Especial de Formação Integral, na qual o docente, além do tempo de trabalho com os alunos, permanece na escola antes ou depois deste horário, para participar da formação coletiva.

Ocorre que, como muitos professores trabalham em mais de uma escola para complementar seus rendimentos, eles costumam ser impedidos de participar da jornada que propicia o momento de formação, caso contrário, não chegam a tempo de iniciar as atividades no outro local de trabalho. Por esse motivo, o tempo de estudo e de preparo de atividades diferenciadas é praticamente inexistente.

A realidade da educação brasileira, hoje, é essa: salas com um grande número de alunos, para que se assegure o acesso, mas com uma qualidade comprometida. Retoma-se, aqui, a discussão já citada, no Capítulo I desta pesquisa, em que Oliveira e Araújo (2005) afirmam que as políticas de democratização do ensino resolvem o problema do acesso à instituição escolar, mas criam uma outra exclusão dentro da própria escola, que é a do acesso a uma educação de qualidade.

Além das dificuldades com as quais os professores se deparam para desenvolver uma ação diferenciada, há também o problema de que os próprios docentes estão muito acostumados com uma configuração mais tradicional de sala de aula, onde o professor é a figura principal, que tem como função transmitir conhecimento a um grupo de alunos, dos quais espera-se o maior aproveitamento possível. Todavia, a organização com a qual a grande maioria das escolas está habituada, a forma de tradicional de transmissão de conhecimentos é, justamente, o que tem ajudado a perpetuar os índices de fracasso dos educandos.

Por muitos anos, a escola se organizou desta forma, e esta organização ainda pode ser encontrada nas escolas e nas ações de boa parcela dos docentes que atuam no Ensino Fundamental I - prova disso é o fato de que a maior parte das salas, observadas na pesquisa de campo, possuía uma configuração extremamente tradicional de ensino. É necessário que se rompa com as práticas que têm perpetuado o fracasso dentro das escolas, abrindo espaço para as novas configurações de ensino que a sala de aula assume atualmente.

Considerando o quadro apresentado, conclui-se que é necessária uma modificação grande no cenário educacional brasileiro, para que a diferenciação pedagógica possa, um dia, 
compor a maior parte das práticas pedagógicas desenvolvidas, com o intuito de promover o sucesso na aprendizagem.

Ressalta-se, mais uma vez, que este é um estudo de proporções pequenas, que não abrange todas as escolas e professores que fazem parte da rede de ensino pesquisada, e que encontrou diversos percalços dentro do próprio universo pesquisado.

Espera-se que outros estudos possam ser desenvolvidos sobre o tema, a fim de se estabelecer uma discussão sólida sobre diferenciação pedagógica no Brasil, subsidiando, assim, as políticas educacionais, e viabilizando a implantação destas ações dentro das escolas da rede pública de ensino. Diferenciar o ensino, considerando a heterogeneidade presente entre os alunos, é uma forma de se buscar a garantia de uma educação de qualidade, que contribua com o sucesso de todos. 


\section{REFERÊNCIAS ${ }^{13}$}

ANDRÉ, Marli Elisa Dalmazo de Afonso (org). Pedagogia das diferenças na sala de aula. $9^{\mathrm{a}}$ ed., Campinas: Papirus, 2008.

ABBOTT, L. Differentiation in Teaching and Learning: aspirations and reality in primary education. Thesis (PhD). University of Ulster (Northen Ireland), 2001.

BAUER, Adriana. Do direito à educação à noção de quase-mercado: tensões na política de educação básica brasileira. RBPAE, v.24, n.3, p. 557-575, set/dez. 2008

BAUER. GASKELL (orgs). Pesquisa qualitativa com texto, imagem e som - um manual prático. Tradução de Pedrinho A. Guareshi. - 11. ed. Petrópolis: Vozes, 2013.

BRASIL. Secretaria de Educação Fundamental. Parâmetros curriculares nacionais: introdução aos parâmetros curriculares nacionais / Secretaria de Educação Fundamental. Brasília: MEC/SEF, 1997. 126p.

BRASIL. Ministério da Educação. Secretaria de Educação Básica. Diretrizes Curriculares Nacionais Gerais da Educação Básica. Brasília: MEC, SEB, DICEI, 2013.

BRASIL. Lei de diretrizes e bases da educação nacional. Brasília: Senado Federal, Coordenação de Edições Técnicas, 2017.

BRASIL, Secretaria de Educação Básica. Diretoria de Apoio à Gestão Educacional. Pacto Nacional pela Alfabetização na Idade Certa. Currículo na perspectiva da inclusão e da diversidade: as Diretrizes Curriculares Nacionais da Educação Básica e o ciclo de alfabetização. Caderno 01/ Ministério da Educação, Brasília: MEC, SEB, 2015.

BRASIL, Secretaria de Educação Básica. Diretoria de Apoio à Gestão Educacional. Pacto Nacional pela Alfabetização na Idade Certa. PNAIC em Ação. Caderno 02/ Ministério da Educação, Brasília: MEC, SEB, 2016.

CLAPARÉDE, Édouard. A escola sob medida. Tradução de Maria Lúcia do Eirado Silva. Rio de Janeiro, Ed. Fundo de Cultura, 1959.

CORTESÃO, Luísa. A importância de dispositivos de diferenciação pedagógica. Faculdade de Psicologia e Ciências da Educação da Universidade do porto, 1998.

CRAHAY, Marcel. Que pedagogia para alunos em dificuldade escolar? Cadernos de Pesquisa, São Paulo, v. 37, n. 130, p. 181-208, jan./abr. 2007.

DUARTE, Clarisse Seixas. Direito público subjetivo e políticas educacionais. São Paulo em Perspectiva, São Paulo, v.18, n. 2, p. 113-118, Abr./Jun. 2004.

${ }^{13}$ De acordo com a Associação Brasileira de Normas Técnicas (ABNT NBR 6023). 
DUBET, François. O que é uma escola justa? Cadernos de Pesquisa, São Paulo, v. 34, n. 123, p. 539-555, set./dez. 2004.

GADOTTI, Moacir. História das ideias pedagógicas. São Paulo, Ática, 1995.

GOMES, Mario Henrique de Jesus. A organização do trabalho na pedagogia diferenciada ao nível do $1^{\circ}$ ano do Ensino Básico: um estudo comparativo entre os modelos High/Scope e do movimento pedagógico da escola moderna. $590 \mathrm{f}$. Tese de doutorado. Orientador: Maria Manuela Malheiro Ferreira, Lisboa, 2013.

GOUVEIA, Maria Fernanda Batista Pestana. Gestão flexível do currículo rumo à diferenciação pedagógica. 439f. Contributos para a promoção de aprendizagens significativas: um estudo numa escola do $1^{\circ}$ Ciclo do Ensino Básico da RAM Tese (doutorado). Orientador: Jesus Maria Angélica Fernandes Sousa, Universidade da Madeira, 2014.

HALL. T; STRANGMAN. N; MEYER. A. Differentiated Instructions and Implications for UDL Implementation. NCAC Effective Classroom Practices. 2002.

HEACOX, Diane. Diferenciação curricular na sala de aula. Tradução de João Félix Almeida. Portugal: Porto Editora, 2006.

McGARVEY, Brian; MARRIOT, Stuart; MORGAN, Valerie; ABBOTT, Leslie. Planejando para a diferenciação: a experiência de professores de escolas primárias da Irlanda do Norte. Práxis Educativa, Ponta Grossa, v.4, n.1, p.63-72, jan-jun. 2009.

MAINARDES, J. Projeto Diferenciação: criando classes mais igualitárias por meio do trabalho diversificado. Ponta Grossa: UEPG, 2007. (Disponível em: http://www.uepg.br/gppepe). Acessado em: 07/12/2015.

MAINARDES, J. A escola em ciclos: fundamentos e debates. São Paulo: Cortez, 2009. (Coleção Questões da nossa época; v.137)

MELLO, L.C.LR. Currículo, práticas educativas e diferenciação pedagógica no préescolar e ciclo I. Relatório de estágio, 99 f. Universidade dos Açores, Ponta Delgada, 2011.

MINAYO, M.C.S.; MINAYO-GÓMEZ, C. Difíceis e possíveis relações entre métodos quantitativos e qualitativos nos estudos de problemas de saúde. In: P. GOLDENBERG; 102.

MORICONI, Gabriela Miranda (coord.). Formação continuada de professores: contribuições da literatura baseada em evidências. São Paulo: FCC, 2017. 59 p.; (Textos FCC: Relatórios técnicos, 52).

OLIVEIRA, Romualdo Portela de; ARAÚJO, Gilda Cardoso. Qualidade do ensino: uma nova dimensão da luta pelo direito à educação. Revista Brasileira de Educação, Rio de Janeiro, n.28, Jan-Abr/2005.

PACHECO, José Augusto. Notas sobre diversificação/diferenciação curricular em Portugal. InterMeio: revista do Programa de Pós-Graduação em Educação, Campo Grande, v. 14, n. 28 , p. 178-18, jul-dez/2008. 
PERRENOUD, Philippe. Os ciclos de aprendizagem: um caminho para combater o fracasso escolar. Porto Alegre: Artmed, 2004.

PERRENOUD, Philippe. Pedagogia diferenciada: das intenções à ação. Tradução: Patrícia Chittoni Ramos. - Porto Alegre: Artes Médicas Sul, 2000.

R.M.G. MARSIGLIA; M.H.A. GOMES (org.), O clássico e o novo: Tendências, objetos e abordagens em ciências sociais e saúde. Rio de Janeiro, Fiocruz, 2003, p. 117-142.

ROLDÃO, Maria do Céu. Diferenciação curricular revisitada. Portugal: Porto Editora, 2003.

SANTOS, Leonor. Diferenciação pedagógica: um desafio a enfrentar. Instituto de Educação, Universidade de Lisboa, 2009.

SÃO PAULO (SP). Secretaria Municipal de Educação. Diretoria de Orientação Técnica. Orientações curriculares: expectativas de aprendizagens e orientações didáticas para Educação Infantil / Secretaria Municipal de Educação - São Paulo: SME / DOT, 2007.

STOER, S; RODRIGUES, D; MAGALHÃES, M. Os lugares da exclusão social: um dispositivo de diferenciação pedagógica. São Paulo: Cortez, 2004.

TOMLINSOM, Carol Ann. Differentiation of Instruction in the Elementary Grades, ERIC Digests, 2000

TRIVIÑOS, A. N. S. Introdução à pesquisa em ciências sociais: a pesquisa qualitativa em educação. São Paulo: Atlas, 1987. 


\section{APÊNDICE - A \\ RESULTADOS DAS BUSCAS BIBLIOGRÁFICAS}

\section{Google Scholar}

\begin{tabular}{|c|c|c|c|}
\hline Descritor utilizado & Título & Autor & Ano de publicação \\
\hline diferenciação pedagógica & $\begin{array}{c}\text { Os lugares da exclusão social: } \\
\text { um dispositivo de } \\
\text { diferenciação pedagógica }\end{array}$ & Stoer, Stephen R. & 2004 \\
\hline pedagogia diferenciada & $\begin{array}{c}\text { Pedagogia diferenciada: das } \\
\text { intenções à ação }\end{array}$ & $\begin{array}{c}\text { Perrenoud, } \\
\text { Phillipe }\end{array}$ & 2000 \\
\hline práticas diferenciadas de \\
ensino
\end{tabular}


Scielo - Scientific Library On-line

\begin{tabular}{|c|c|c|c|}
\hline Descritor Utilizado & Título & Autor & Ano de publicação \\
\hline \multirow[t]{2}{*}{$\begin{array}{l}\text { Diferenciação } \\
\text { pedagógica }\end{array}$} & $\begin{array}{c}\text { Professor: produtor } \\
\text { e/ou tradutor de } \\
\text { conhecimentos? } \\
\text { Trabalhando no } \\
\text { contexto do arco-íris } \\
\text { sociocultural da sala } \\
\text { de aula }\end{array}$ & Luísa Cortesão & 2012 \\
\hline & $\begin{array}{l}\text { Um sistema de } \\
\text { acompanhamento das } \\
\text { crianças (SAC) em } \\
\text { jardim-de-infância: } \\
\text { Uma via para a } \\
\text { diferenciação } \\
\text { pedagógica e } \\
\text { inclusão }\end{array}$ & $\begin{array}{c}\text { Paula Santos; } \\
\text { Gabriela Portugal; } \\
\text { Ofélia Libório, et all }\end{array}$ & 2011 \\
\hline \multirow{2}{*}{$\begin{array}{l}\text { Pedagogia } \\
\text { Diferenciada }\end{array}$} & $\begin{array}{c}\text { Interculturalidad y } \\
\text { pedagogía } \\
\text { diferenciada: } \\
\text { senderos } \\
\text { compartidos }\end{array}$ & $\begin{array}{l}\text { Guillermo Rojas } \\
\text { Trujillo }\end{array}$ & 2012 \\
\hline & $\begin{array}{l}\text { Política educativa, } \\
\text { educação inclusiva e } \\
\text { diferenciação ou } \\
\text { «Como posso fazer } \\
\text { pedagogia } \\
\text { diferenciada se tenho } \\
\text { vinte e oito alunos e } \\
\text { quatro são diferentes } \\
\text { dos outros? }\end{array}$ & José Morgado & 1999 \\
\hline $\begin{array}{l}\text { Práticas } \\
\text { diferenciadas de } \\
\text { ensino }\end{array}$ & \multicolumn{3}{|c|}{$\begin{array}{l}\text { Foram encontrados } 9 \text { resultados, mas nenhum compatível com o tema } \\
\text { em estudo }\end{array}$} \\
\hline $\begin{array}{l}\text { Instrução } \\
\text { diferenciada }\end{array}$ & \multicolumn{3}{|c|}{$\begin{array}{l}\text { Foram encontrados } 2 \text { resultados com este descritor, mas nenhum } \\
\text { compatível com o tema } \\
\text { em estudo }\end{array}$} \\
\hline $\begin{array}{l}\text { Differentiated } \\
\text { Instruction }\end{array}$ & \multicolumn{3}{|c|}{$\begin{array}{l}\text { Foram encontrados } 2 \text { resultados com este descritor, mas nenhum } \\
\text { compatível com o tema em estudo }\end{array}$} \\
\hline
\end{tabular}


UCL Library

\begin{tabular}{|c|c|c|c|}
\hline Descritor utilizado & Título & Autor & Ano \\
\hline \multirow{8}{*}{$\begin{array}{l}\text { Differentiated } \\
\text { Instruction }\end{array}$} & $\begin{array}{l}\text { Differentiation in Teaching and } \\
\text { Learning: } \\
\text { aspirations and reality in primary } \\
\text { education }\end{array}$ & $\begin{array}{l}\text { Lesley Eleanor } \\
\text { Abbott, B.Sc., } \\
\text { M.A. }\end{array}$ & 2001 \\
\hline & Decinding to teach to them all & $\begin{array}{l}\text { Carol Ann } \\
\text { Tomlinsom }\end{array}$ & 2003 \\
\hline & $\begin{array}{l}\text { Differentiated Instruction and } \\
\text { Implications } \\
\text { for UDL Implementation }\end{array}$ & $\begin{array}{c}\text { Tracey Hall, } \\
\text { Nicole Strangman } \\
\text { and Anne Meyer }\end{array}$ & 2002 \\
\hline & $\begin{array}{l}\text { Differentiated instruction: A } \\
\text { research basis }\end{array}$ & Pearl Subban & 2006 \\
\hline & $\begin{array}{c}\text { Differentiating Instruction in } \\
\text { Response } \\
\text { to Student Readiness, Interest, and } \\
\text { Learning } \\
\text { Profile in Academically Diverse } \\
\text { Classrooms: } \\
\text { A Review of Literature } \\
\end{array}$ & $\begin{array}{c}\text { Carol Ann } \\
\text { Tomlinsom et al. }\end{array}$ & 2003 \\
\hline & $\begin{array}{c}\text { Meeting the Needs of All Students } \\
\text { through } \\
\text { Differentiated Instruction: Helping } \\
\text { Every Child } \\
\text { Reach and Exceed Standards }\end{array}$ & Holli M. Levy & 2010 \\
\hline & $\begin{array}{c}\text { Differentiation of } \\
\text { Instruction in the Elementary } \\
\text { Grades. }\end{array}$ & $\begin{array}{l}\text { Carol Ann } \\
\text { Tomlinsom }\end{array}$ & 2000 \\
\hline & $\begin{array}{l}\text { Sharing Responsibility for } \\
\text { Differentiating Instruction }\end{array}$ & $\begin{array}{l}\text { Carol Ann } \\
\text { Tomlinsom }\end{array}$ & 2010 \\
\hline
\end{tabular}

Banco de Teses e Dissertações da CAPES

\begin{tabular}{|c|c|}
\hline Descritor utilizado & Resultados \\
\hline Pedagogia Diferenciada & $\begin{array}{c}\text { Foram encontrados 8 resultados, mas nenhum compatível } \\
\text { com a pesquisa }\end{array}$ \\
& \\
\hline
\end{tabular}


Resultados da pesquisa com novos descritores

\begin{tabular}{|c|c|c|c|}
\hline $\begin{array}{l}\text { Descritor } \\
\text { utilizado }\end{array}$ & Título & Autor & Ano \\
\hline \multirow{4}{*}{$\begin{array}{l}\text { Atenção à } \\
\text { diversidade }\end{array}$} & $\begin{array}{c}\text { A diversidade na escola e as } \\
\text { novas demandas }\end{array}$ & $\begin{array}{c}\text { Gustavo Bruno } \\
\text { Bicalho Gonçalves }\end{array}$ & 2013 \\
\hline & $\begin{array}{c}\text { Dilemas e desafios na } \\
\text { educação primária: } \\
\text { implicações na atenção à } \\
\text { diversidade } \\
\end{array}$ & $\begin{array}{l}\text { José Domínguez } \\
\text { Alonso }\end{array}$ & 2009 \\
\hline & $\begin{array}{l}\text { Diversidade e as políticas } \\
\text { públicas de educação }\end{array}$ & $\begin{array}{c}\text { Tatiane Cosentino } \\
\text { Rodrigues; Anete } \\
\text { Abramowicz. }\end{array}$ & 2011 \\
\hline & $\begin{array}{l}\text { Educação e diversidade: } \\
\text { demandas do capitalismo } \\
\text { contemporâneo }\end{array}$ & $\begin{array}{l}\text { Mary Ângela } \\
\text { Geraldes; Rosemary } \\
\text { Roggero }\end{array}$ & 2011 \\
\hline $\begin{array}{c}\text { Trabalho } \\
\text { diversificado }\end{array}$ & $\begin{array}{l}\text { Projeto diferenciação: criando } \\
\text { classes mais igualitárias por } \\
\text { meio do atendimento } \\
\text { diversificado }\end{array}$ & Jefferson Mainardes & 2007 \\
\hline $\begin{array}{c}\text { Classes } \\
\text { homogêneas e } \\
\text { heterogêneas }\end{array}$ & \multicolumn{3}{|c|}{ Resultados não condizentes com o tema da pesquisa } \\
\hline
\end{tabular}




\section{APÊNDICE - B \\ INSTRUMENTOS DE PESQUISA: QUESTIONÁRIO, ROTEIROS DE ENTREVISTAS E DE OBSERVAÇÕES}

\section{Questionário inicial}

Caro(a) professor(a):

Este questionário faz parte de uma pesquisa de mestrado do programa de pós-graduação da Faculdade de Educação da Universidade de São Paulo, que tem como objetivo identificar práticas de diferenciação pedagógica dentro da rede municipal de ensino de São Paulo. Agradecemos sua participação e reiteramos que ela é muito importante para a concretização da pesquisa. Os dados obtidos por meio deste questionário serão tratados sigilosamente, não sendo necessária identificação do nome do respondente.

\section{Parte 1 - Caracterização do respondente}

Unidade de exercício:

Q1. Cargo: Assinale o cargo que exerce na unidade escolar neste ano letivo

a) Professor de Educação Infantil e Ensino Fundamental I

b) Professor do Ensino Fundamental I

c) Atualmente sem sala atribuída

Q2. Função: Assinale a função/atribuição que exerce na unidade mencionada acima neste ano letivo
a) Professor titular
b) Professor de sala de leitura
c) Professor de reforço/recuperação paralela
d) Professor de informática educativa
e) Professor CJ/módulo

$\begin{array}{llll}\text { Q3. Ano em que } & \text { 1- } 1^{\circ} \text {. Ano } & \text { Q4. Período: } & \text { a. Manhã } \\ \text { leciona: } & \text { 2- } 2^{\circ} \text {. Ano } & & \text { b. Tarde } \\ & \text { 3- } 3^{\circ} \text {. Ano } & \\ & \text { 4- } 4^{\circ} \text {. Ano } & \\ & \text { 5- } 5^{\circ} \text {. Ano }\end{array}$


Q5.Formação inicial:

Q6.Formação Complementar

Q7.Experiência profissional

\section{Q8.Experiência na série}

Assinale mais de uma alternativa, se for necessário:

1. Nível Médio - Magistério

2. Graduação - Pedagogia

3. Graduação - Licenciatura e complementação pedagógica

4. Complementação pedagógica

5. Graduação - Outros e complementação pedagógica

1. Curso de extensão

2. Curso de aperfeiçoamento

3. Especialização - Pós-graduação - Lato Sensu

4. Mestrado

5. Doutorado

6. Outros. Especifique:

Há quantos anos leciona?
a. Menos de 3 anos
b. De 3 a 5 anos
c. De 6 a 10 anos
d. De 11 a 15 anos
e. Mais de 16 anos

Há quantos anos leciona nesta série/ano?
a. Menos de 3 anos
b. De 3 a 5 anos
c. De 6 a 10 anos
d. De 11 a 15 anos
e. Mais de 16 anos

\section{Parte 2 - Diferenciação Pedagógica}

A diferenciação pedagógica, em breves linhas, pode ser entendida como uma série de medidas tomadas pelo professor no sentido de adaptar o processo de ensino às diferenças existentes entre os alunos, com o intuito de tentar promover aprendizagens significativas para todos. Tais ações permitiriam o alcance dos objetivos propostos para os alunos e, consequentemente, o aumento dos níveis de sucesso escolar. Considerando esta definição, responda as questões abaixo: 
Q9. Assinale se você já ouviu falar ou não de cada uma das expressões listadas abaixo:

\begin{tabular}{|l|l|l|l|}
\hline & SIM & NÃO & NÃO ME \\
& & & LEMBRO \\
\hline Diferenciação pedagógica & & & \\
\hline Pedagogia diferenciada & & & \\
\hline Instrução diferenciada & & & \\
\hline Práticas diferenciadas de ensino & & & \\
\hline
\end{tabular}

Q10. Se você assinalou SIM para um ou mais conceitos apresentados na questão 9, defina brevemente o que entende sobre cada um deles nas linhas a seguir:

Q11. Se você pratica algum tipo de diferenciação pedagógica com seus alunos, assinale de que forma a realiza (é possível assinalar mais de uma opção)

1. Não diferencia

2. Diferencia o currículo/os conteúdos ensinados

3. Diferencia as práticas/estratégias de ensino

4. Diferencia a intervenção pedagógica junto ao aluno

5. Diferencia as atividades propostas para os alunos

6. Diferencia os materiais usados na sala de aula

7. Diferencia expectativas de aprendizagem

Q12. Com que frequência você realiza as atividades de diferenciação citadas acima? Assinale com $\mathrm{X}$ a alternativa escolhida.

\begin{tabular}{|l|l|l|l|}
\hline & Frequentemente & Ocasionalmente & Nunca \\
\hline 1. não diferencia & & & \\
\hline 2. diferencia o currículo/os conteúdos ensinados & & & \\
\hline $\begin{array}{l}\text { 3. diferencia as práticas/estratégias de ensino } \\
\text { 4. diferencia a intervenção pedagógica junto ao } \\
\text { aluno }\end{array}$ & & & \\
\hline
\end{tabular}




\begin{tabular}{|l|l|l|}
\hline $\begin{array}{l}\text { 5. diferencia as atividades propostas para os } \\
\text { alunos }\end{array}$ & & \\
\hline 6. diferencia os materiais usados na sala de aula & & \\
\hline 7. Diferencia expectativas de aprendizagem & & \\
\hline
\end{tabular}

Q13. Com relação à questão 11 , se assinalou "sim" em algum dos itens, poderia descrever brevemente como ocorre $(\mathrm{m})$ essa(s) prática(s)?

Q14. Você considera que a diferenciação, em suas diversas possibilidades (currículo/conteúdos, estratégias de ensino, intervenção pedagógica, atividades, materiais, expectativas) é uma medida importante para o processo de ensino e aprendizagem? Por quê?

Q15. Você já ouviu falar desse tipo de prática pedagógica, mas com uma outra nomenclatura/termos? Se sim, com qual?

Muito obrigada! 
Roteiro de entrevista para professores

Bloco 1 - Identificação

1. Série que leciona:

2. Tempo de magistério:

3. Tempo de exercício na prefeitura de São Paulo:

4. Tempo de exercício NESTA escola:

5. Tempo de experiência NESTA série:

6. Carga horária de trabalho semanal (incluindo todas as atividades, inclusive nãodocentes):

7. Qual foi a sua formação inicial?

8. Possui outros cursos (pós-graduação, extensão, formação continuada)?

Bloco 2 - Percepções docentes

9. Você percebe diferenças entre seus alunos? Que tipo de diferenças?

10. A que atribui essas diferenças? 
11. Essas diferenças influenciam o seu fazer pedagógico? Se sim, de que maneira? Se não, por quê?

12. Você planeja o ensino pensando num contexto mais heterogêneo? Exemplifique esse tipo de planejamento.

13. Sua escola tem projetos/ações/iniciativas visando a garantia da aprendizagem de todos os alunos, o respeito às diferenças cognitivas individuais e o combate ao fracasso escolar? Explique.

14. Que tipo de trabalho é realizado? Poderia exemplificar? 
15. Você considera essas diretrizes em seu trabalho, no seu planejamento, na organização dos conteúdos que quer ensinar?

16. Você utiliza estratégias para garantir que todos aprendam o esperado para sua série/ano? Poderia exemplificar?

17. O que é feito se se percebe que os alunos não desenvolveram aspectos esperados com as estratégias rotineiramente utilizadas?

18. O que você entende por diferenciação pedagógica? Já conhecia este conceito?

Questões comuns para gestores e professores

1. Há um programa de reforço para os alunos?

2. Os conteúdos são definidos coletivamente por todos os professores da série? Há planejamento em conjunto? Recebem orientações para esse planejamento? Há um programa de replanejamento?

3. Quanto os professores usam esse planejamento para nortear suas próprias ações?

4. Há orientações sobre como distribuir carga e material didático? Sobre como avaliar? 
5. A escola tem clareza de quanto espera em termos de aprendizagem dos alunos?

6. A escola faz o acompanhamento da cobertura curricular durante todo o ano letivo?

7. Há alguma ação especifica para atender alunos que demandem outros tipos de intervenção/ atenção, por exemplo, alunos que se destacam cognitivamente, alunos mais inquietos, mais tímidos, ou seja, atender a diversidade de alunos de uma sala de aula?

\section{Modelo de Entrevista Semiestruturada para Gestores}

1. Qual sua formação?

2. Tempo de magistério:

3. Tempo de exercício na prefeitura de São Paulo:

4. Há quanto tempo exerce o cargo/função?

5. Há quanto tempo está nesta escola nesta função?

6. Carga horária de trabalho semanal (incluindo todas as atividades, inclusive nãodocentes):

7. Qual foi a sua formação inicial?

8. Possui outros cursos (pós-graduação, extensão, formação continuada)?

9. A escola tem diretrizes de trabalho visando a aprendizagem de todos os alunos? 
10. A escola pensa/projeta o trabalho considerando as diferenças entre os alunos?

11. A escola tem projetos visando o atendimento das diferenças individuais de aprendizagem?

12. A escola orienta/faz discussões com os professores visando o atendimento das diferenças individuais dos alunos? Poderia exemplificar?

13. As ações realizadas na escola com o intuito de se atender as diferenças cognitivas /e fazer com que todos aprendam têm alguma fundamentação teórica específica? 
14. Você já ouviu falar de diferenciação pedagógica? O que entende por isso?

15. Na sua percepção, a SME tem projetos ou está atenta para a questão da aprendizagem de todos os alunos, o respeito às diferenças cognitivas individuais e o combate ao fracasso escolar? Se sim, como essa atenção se expressa em termos de políticas públicas?

\section{Questões comuns aos dois questionários}

1. Há um programa de reforço para os alunos?

2. Os conteúdos são definidos coletivamente por todos os professores da série? Há planejamento em conjunto? Recebem orientações para esse planejamento? Há um programa de replanejamento?

3. Quanto os professores usam esse planejamento para nortear suas próprias ações?

4. Há orientações sobre como distribuir carga e material didático? Sobre como avaliar?

5. A escola tem clareza de quanto espera em termos de aprendizagem dos alunos?

6. A escola faz o acompanhamento da cobertura curricular durante todo o ano letivo?

7. Há alguma ação especifica para atender alunos que demandem outros tipos de intervenção/ atenção, por exemplo, alunos que se destacam cognitivamente, alunos mais inquietos, mais tímidos, ou seja, atender a diversidade de alunos de uma sala de aula? 


\section{Roteiro de observação}

\section{Escola:}

Ano:

Período:

Professor:

\begin{tabular}{|c|c|c|c|c|c|}
\hline \multicolumn{4}{|c|}{ Bloco 1 - Organização física da sala de aula e dos alunos } \\
\hline Organização das carteiras & Sim & Não & $\begin{array}{c}\text { Agrupamento de } \\
\text { alunos }\end{array}$ & Sim & Não \\
\hline Uma após a outra & & & Individual & & \\
\hline $\begin{array}{c}\text { Organizadas em círculos ou em } \\
\text { forma de "U”, como em um } \\
\text { plenário }\end{array}$ & & Pares ou grupos & & \\
\hline Outras formas de organização & & & Pares ou grupos & & \\
\hline
\end{tabular}

\begin{tabular}{|c|c|c|c|c|c|}
\hline $\begin{array}{l}\text { Critérios de organização nos } \\
\text { agrupamentos }\end{array}$ & Sim & Não & \multicolumn{3}{|c|}{ Comentários } \\
\hline \multicolumn{6}{|l|}{ Nível de conhecimento } \\
\hline \multicolumn{6}{|l|}{ Tipo de atividade } \\
\hline \multicolumn{6}{|l|}{ Conteúdo trabalhado } \\
\hline \multicolumn{6}{|l|}{ Comportamento } \\
\hline \multicolumn{6}{|l|}{ Sexo } \\
\hline \multicolumn{6}{|l|}{ Faixa etária } \\
\hline \multicolumn{6}{|c|}{$\begin{array}{l}\text { Comentários sobre as relações entre as formas de organização da sala e a sua relação com a } \\
\text { diferenciação }\end{array}$} \\
\hline \multicolumn{6}{|c|}{ Bloco 2 - Práticas pedagógicas } \\
\hline \multicolumn{3}{|c|}{ Diferenciação de conteúdo/currículo } & Sim & Não & Parcialmente \\
\hline \multicolumn{6}{|c|}{$\begin{array}{l}\text { O professor trabalha com listas de materiais de diferentes } \\
\text { níveis? }\end{array}$} \\
\hline \multicolumn{3}{|c|}{$\begin{array}{l}\text { As atividades propostas estão de acordo com os níveis dos } \\
\text { alunos? }\end{array}$} & & & \\
\hline \multicolumn{3}{|c|}{$\begin{array}{l}\text { O professor reúne pequenos grupos para reforçar uma ideia } \\
\text { ou habilidade, no caso de alunos que apresentam } \\
\text { dificuldades? }\end{array}$} & & & \\
\hline \multicolumn{3}{|c|}{$\begin{array}{l}\text { O professor reúne pequenos grupos para ampliar o } \\
\text { pensamento ou as habilidades dos alunos que se encontram } \\
\text { em níveis avançados? }\end{array}$} & & & \\
\hline
\end{tabular}




\begin{tabular}{|c|c|c|c|}
\hline $\begin{array}{l}\text { O professor ministra conteúdos diferentes para um aluno } \\
\text { ou outro? }\end{array}$ & & & \\
\hline $\begin{array}{l}\text { O professor sintetiza, muda, acrescenta atividades para } \\
\text { alguns? }\end{array}$ & & & \\
\hline $\begin{array}{l}\text { A sequência do ensino de certos conteúdos é diferente para } \\
\text { alguns alunos? }\end{array}$ & & & \\
\hline Diferenciação de práticas de ensino & Sim & Não & Parcialmente \\
\hline $\begin{array}{l}\text { Diferentes formas que o professor utiliza para fazer com } \\
\text { que todos aprendam }\end{array}$ & & & \\
\hline $\begin{array}{l}\text { Se uma tática não deu certo, o professor busca novas } \\
\text { estratégias para ensinar o aluno? }\end{array}$ & & & \\
\hline Diferenciação de intervenção pedagógica & Sim & Não & Parcialmente \\
\hline $\begin{array}{l}\text { o professor utiliza diversas formas de intervir/ auxiliar os } \\
\text { alunos no processo de aprendizagem, conforme as } \\
\text { necessidades apresentadas por eles. }\end{array}$ & & & \\
\hline $\begin{array}{l}\text { O professor busca novas formas de auxiliar o aluno na } \\
\text { aquisição do conhecimento? Trabalha individualmente, } \\
\text { explica novamente utilizando outra linguagem }\end{array}$ & & & \\
\hline $\begin{array}{l}\text { A atenção dispensada pelo professor aos alunos é } \\
\text { diferente com relação a cada necessidade, sem, no } \\
\text { entanto, que isso se configure como uma ação de } \\
\text { discriminação negativa dentro da sala de aula. }\end{array}$ & & & \\
\hline Diferenciação de atividades & Sim & Não & Parcialmente \\
\hline $\begin{array}{l}\text { O professor aplica atividades referentes a um mesmo } \\
\text { conteúdo, mas com graus de dificuldade diferentes } \\
\text { conforme o nível dos alunos. }\end{array}$ & & & \\
\hline $\begin{array}{l}\text { O professor aplica atividades com comandas diferentes de } \\
\text { acordo com o aluno. }\end{array}$ & & & \\
\hline Diferenciação de materiais & Sim & Não & Parcialmente \\
\hline $\begin{array}{l}\text { São utilizados diferentes tipos de materiais e/ou recursos } \\
\text { pedagógicos (jogos, material dourado, letras móveis, } \\
\text { dentre outros) na explicação dos conteúdos, para que haja } \\
\text { maior entendimento do que está sendo ensinado e todos os } \\
\text { alunos possam atingir os objetivos propostos. }\end{array}$ & & & \\
\hline $\begin{array}{l}\text { Durante a realização de atividades, são disponibilizados } \\
\text { materiais pedagógicos diversos aos alunos, com o intuito } \\
\text { de promover experiências que possam satisfazer a todos. }\end{array}$ & & & \\
\hline Diferenciação de expectativas de aprendizagem & Sim & Não & Parcialmente \\
\hline $\begin{array}{l}\text { O professor diferencia o que espera que os alunos } \\
\text { aprendam, conforme suas possibilidades, sem, no entanto, } \\
\text { limitar o desenvolvimento dos mesmos? }\end{array}$ & & & \\
\hline
\end{tabular}




\begin{tabular}{|l|l|l|l|}
\hline $\begin{array}{l}\text { O professor trabalha aquém ou além do nível de } \\
\text { desenvolvimento dos alunos? }\end{array}$ & & \\
\hline Diferenciação de produtos & Sim & Não & Parcialmente \\
\hline $\begin{array}{l}\text { O professor possibilita aos estudantes opções de como } \\
\text { expressar sua aprendizagem (elaborando uma peça de } \\
\text { teatro; desenvolvendo cartazes para apresentar os } \\
\text { conteúdos à sala; elaborando murais informativos sobre os } \\
\text { conteúdos adquiridos). }\end{array}$ & & & \\
\hline $\begin{array}{l}\text { O professor permite que os alunos trabalhem sozinhos ou } \\
\text { em pequenos grupos em seus produtos de aprendizagem; }\end{array}$ & & & \\
\hline $\begin{array}{l}\text { O professor incentiva os alunos a elaborarem suas próprias } \\
\text { criações, ou seja, seu próprio produto de aprendizagem. }\end{array}$ & & & \\
\hline $\begin{array}{l}\text { Análise do entendimento conceitual da diferenciação } \\
\text { pedagógica nos discursos docentes }\end{array}$ & Sim & Não & Parcialmente \\
\hline $\begin{array}{l}\text { Os professores demonstram embasamento teórico em suas } \\
\text { falas ao definirem o que entendem por diferenciação }\end{array}$ & & & \\
\hline $\begin{array}{l}\text { As falas dos professores se baseiam-se na relação entre o } \\
\text { conceito apresentado com a própria prática em sala de aula } \\
\text { (sem que isso signifique que eles tiveram contato com os } \\
\text { estudos sobre diferenciação). }\end{array}$ & & & \\
\hline
\end{tabular}

Bloco 3 - Relacionamento entre professor e alunos

\begin{tabular}{|l|l|l|l|}
\hline Diferenças de tratamento do professor em relação aos alunos & Sim & Não & Parcialmente \\
\hline $\begin{array}{l}\text { Mais exigente com os que considera bons alunos, mais } \\
\text { complacente com os que considera alunos com dificuldades ou } \\
\text { vice-versa }\end{array}$ & & & \\
\hline $\begin{array}{l}\text { Mais impaciente com alunos com dificuldade } \\
\text { Demonstra mais simpatia e/ou afinidade com os alunos } \\
\text { considerados mais interessados, bem apresentados e } \\
\text { disciplinados? }\end{array}$ & & & \\
\hline $\begin{array}{l}\text { De modo geral, se existe diferenciação no tratamento aos alunos, } \\
\text { esta diferenciação é negativa ou positiva? }\end{array}$ & & & \\
\hline
\end{tabular}


Outras observações 


\section{APÊNDICE - C}

Tabela com resultados detalhados sobre a importância de diferenciar o ensino.

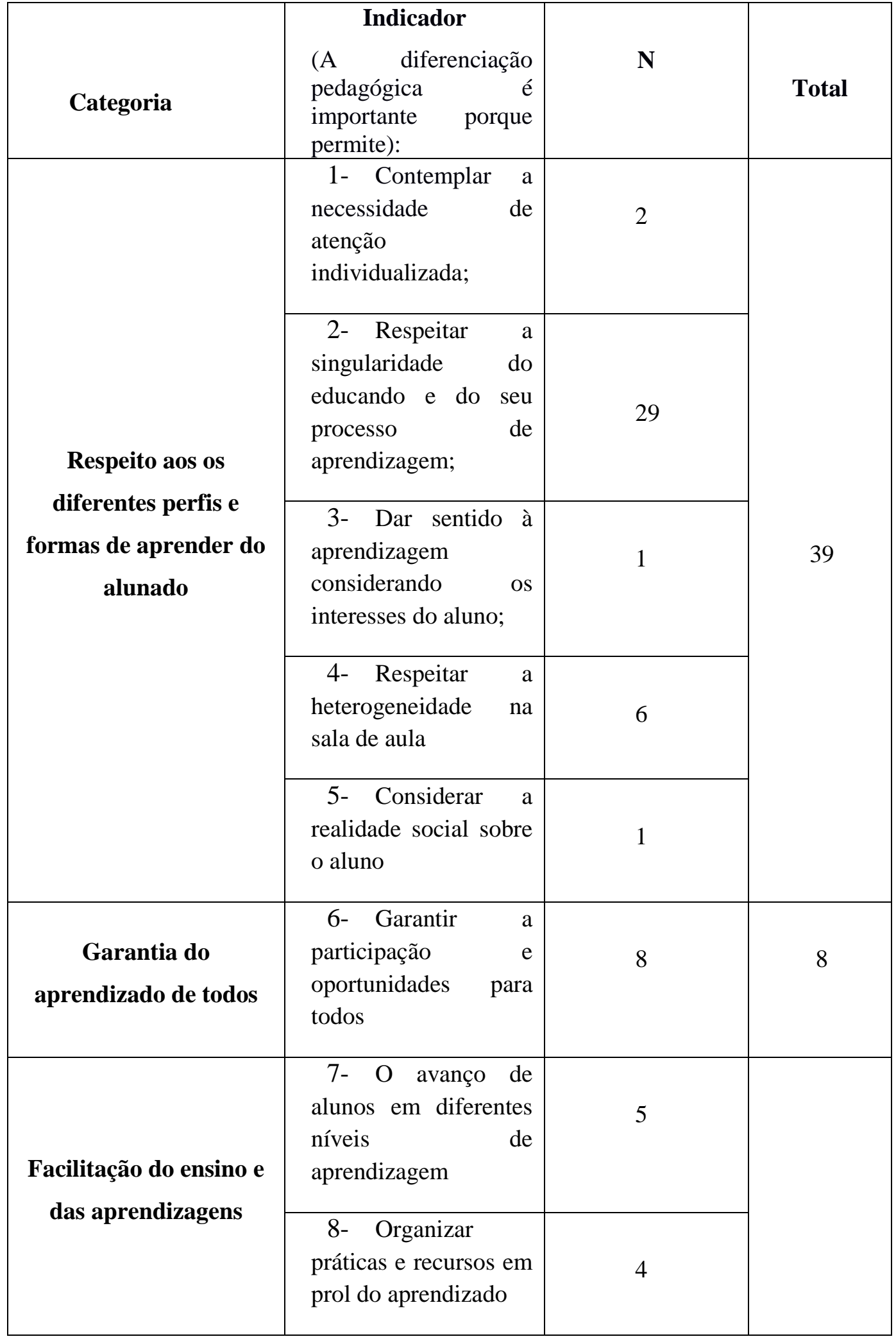




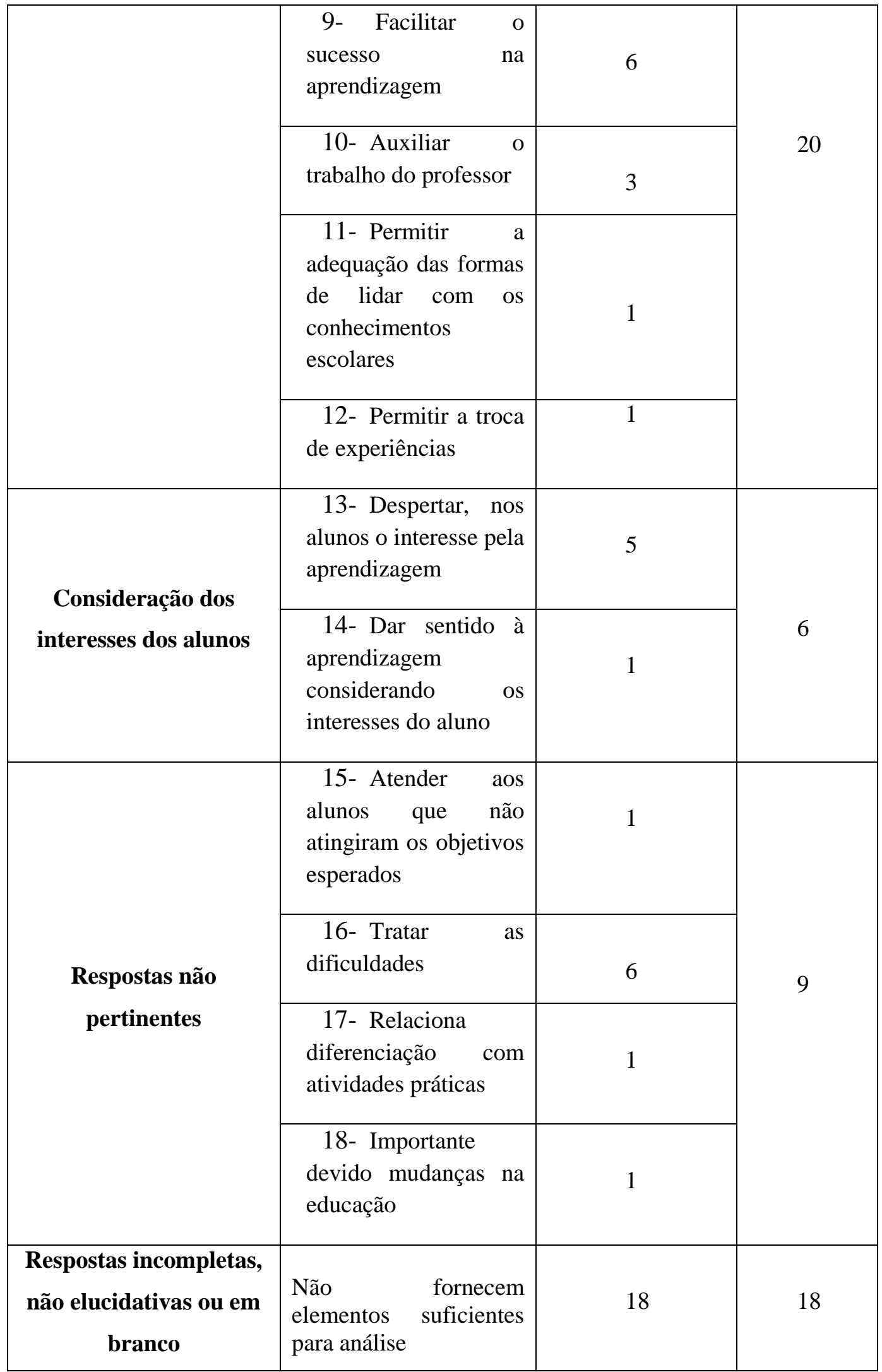

